Universidade de Brasília Instituto de Artes

Departamento de Desenho Industrial Programa de Pós-Graduação em Design

PAULA COUTO LOPES DE ARAUJO FARIA

\title{
Infografia digital em sites do governo federal: processos de elaboração e linguagens gráficas
}

Brasília, 2015 
PAULA COUTO LOPES DE ARAUJO FARIA

\section{Infografia digital em sites do governo federal: processos de elaboração e linguagens gráficas}

Dissertação apresentada ao Departamento de Desenho Industrial da Universidade de Brasília como trabalho de conclusão de curso de Mestrado na área de concentração de Design, Tecnologia e Sociedade, orientada pela

Profa Dra Virgínia Tiradentes Souto.

Brasília, 2015 
Ficha catalográfica elaborada automaticamente, com os dados fornecidos pelo(a) autor(a)

Faria, Paula

Infografia digital em sites do governo federal: processos de elaboração e linguagens gráficas / Paula Faria; orientador Virgínia Tiradentes Souto. -Brasília, 2015. $93 \mathrm{p}$.

Dissertação (Mestrado - Mestrado em Design) -Universidade de Brasília, 2015.

1. Design da informação. 2. Infografia digital. 3 . Lei de acesso à informação. I. Souto, Virgínia Tiradentes, orient. II. Título. 


\section{INFOGRAFIA DIGITAL EM SITES DO GOVERNO FEDERAL: PROCESSOS DE ELABORAÇÃO E LINGUAGENS GRÁFICAS}

\section{Paula Couto Lopes de Araujo Faria}

Dissertação submetida ao Programa de Pós-Graduação em Design do Instituto de Artes da Universidade de Brasília como parte dos requisitos para a obtenção do grau de Mestre em Design.

Aprovada por:

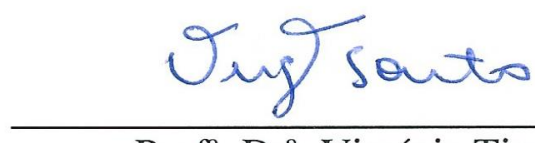

Prof $^{\mathrm{a}}$. Dra . Virgínia Tiradentes Souto

$\mathrm{IdA} / \mathrm{DIn} / \mathrm{UnB}$

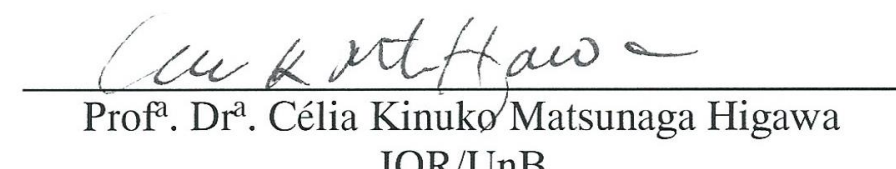

$$
\mathrm{JOR} / \mathrm{UnB}
$$

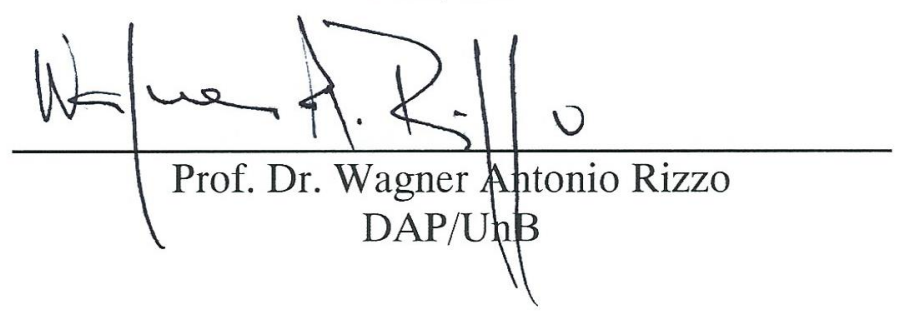

Brasília-DF, 27 de Novembro de 2015

Coordenação do Programa de Pós-Graduação em Design/Instituto de Artes/UnB 


\section{Dedicatória}

Ao Ricardo, meu amado marido e encorajador.

À Olívia e à Isabel, minhas amadas filhas e inspiradoras. 


\section{Agradecimentos}

À minha família: Ricardo, Olívia e Isabel, por compreenderem com carinho e bom humor as horas de estudo e escrita necessárias para o mestrado e para essa dissertação.

Aos meus queridos pais, Irene e Sergio, por me darem a oportunidade de chegar até aqui e por me mostrarem o quanto a persistência é importante para o alcance dos objetivos.

À minha querida sogra Suelena, pelo estímulo e apoio constantes.

À minha orientadora Virgínia, por todo aprendizado, toda contribuição e toda dedicação ao meu projeto, me impulsionando e apontando, com carinho, o caminho do aperfeiçoamento.

Aos professores Celia e Wagner, pela atenção carinhosa e contribuições significantes.

Aos professores do PPG Design, pelo conhecimento proporcionado e pelas palavras de incentivo, em especial às professoras Fátima e Shirley.

À professora Ivette, por me receber com atenção e me incentivar a seguir o caminho do mestrado, desde as aulas como aluna especial na $\mathrm{FCl}$. 
"Busque a simplicidade e então desconfie dela."

"Seek simplicity and then untrust it."

Alfred North Whitehead (1861-1947)

Matemático e Filósofo 


\section{Resumo}

Informações textuais e gráficas em sites do governo brasileiro têm se tornado cada vez mais frequentes, em especial após a publicação da Lei de Acesso a Informações no 12.527 de 2011, que regulamenta o direito constitucional do acesso dos cidadãos às informações públicas. De forma a facilitar esse acesso e romper as barreiras da complexidade do conteúdo, os infográficos foram surgindo como artefatos de visualização e conquistando espaço em sites governamentais no Brasil. Não obstante os numerosos estudos sobre infográficos digitais e jornalísticos, não foram encontrados estudos na literatura sobre os infográficos em sites do governo brasileiro. Não são conhecidos os processos sob os quais esses infográficos são elaborados e quais as ferramentas visuais empregadas em suas soluções. Isto posto, as questões que fomentaram este estudo foram: (a) quais os processos de elaboração de infográficos digitais no governo? e (b) quais as linguagens gráficas neles utilizadas? Para responder estas questões, esta investigação inicia-se com uma visão sobre o design da informação, disciplina diretamente relacionada a infográficos, e um levantamento teórico sobre infografia digital. Para a contextualização do tema governamental, é apresentada uma análise da legislação referente ao acesso a informações públicas no Brasil. Em seguida são apresentados os dois estudos da dissertação. O primeiro estudo refere-se a uma análise de processos de elaboração disponíveis na literatura e uma pesquisa com profissionais que elaboram infográficos para órgãos governamentais, a fim de conhecer os seus processos de elaboração e compará-los com os processos teóricos. O segundo estudo é uma análise de infográficos encontrados em sites do governo brasileiro de acordo com a linguagem gráfica, situando-os em uma matriz que compreende modos de simbolização e métodos de configuração. Conclui-se que os processos de elaboração de infográficos para o governo podem ser aprimorados e que as linguagens gráficas devem estar adequadas aos seus propósitos. Ao final do estudo é proposta uma lista de recomendações sobre processos de elaboração e linguagem gráfica, que tem como objetivo auxiliar o governo e os infografistas na elaboração dos infográficos de informação pública oficial.

Palavras-chave: design, design da informação, infografia digital, lei de acesso à informação. 


\section{Abstract}

Textual and graphical information in Brazilian government websites have become increasingly frequent, especially after the publication of the Law of Access to Information No. 12.527 of 2011, which regulates the constitutional right of citizens' access to public information. In order to facilitate such access and break the barriers of the complexity of its content, infographics were emerging as visual artifacts and gaining ground on government websites in Brazil. Despite the numerous studies on digital and journalistic infographics, there were no findings in literature regarding infographics on Brazilian government websites. Therefore, it is not known the processes under which these infographics are made and which are the visual elements used in their solutions. In such a manner, the issues that fostered this study were: (a) which are the production processes of digital infographics in Brazilian government? and (b) what are the graphic languages used in them? To answer these questions, this research begins with an overview of information design, a discipline directly related to infographics, and a theoretical survey of digital infographics. To contextualize the government theme, this study presents an analysis of the legislation regarding the access to public information in Brazil. Later in the study, the two parts of this research are presented: the first part refers to an analysis of production processes available in literature and a survey with professionals who design infographics in Brazilian government agencies, in order to know their production processes and compare them with the theoretical processes. The second part is an analysis of infographics found in Brazilian government websites according to graphic language, placing them in a matrix comprising symbolization modes and configuration methods. In conclusion, the results show that infographics production processes in the government could be improved and that their graphic languages must be appropriate for their purposes. At the end, the study proposes a list of recommendations, regarding production processes and graphic languages, with the aim to assist both the government and infographics designers in the preparation of official public information infographics.

Key-words: design, information design, digital infographics, law of acesss to information. 


\section{Lista de figuras}

FIGURA 1 Busca pelo termo Design no Google, em maio de 2015.

FIGURA 2 Exemplo de infográfico no governo brasileiro. 15

FIGURA $3 \quad$ Exemplo de infográfico jornalístico dos anos 90.

FIGURA 4 Exemplo de infográfico digital.

FIGURA 5 Área de Centrais de Conteúdo o Portal Padrão. 25

FIGURA 6 Página de central de Infográficos da Identidade Digital do Governo. 26

FIGURA 7 Processo de David Sless (2008) para o design da informação, adaptado e $\mathbf{3 4}$ traduzido.

FIGURA 8 Nuvem de palavras com as vantagens de um infográfico do governo, $\quad \mathbf{5 0}$ gerada pelo Wordle.

FIGURA 9 Exemplo de tags específicas de infográfico.

FIGURA $10 \quad$ Imagem ilustrativa de parte da página da Central de infográficos do $\mathbf{6 2}$ Portal Brasil.

FIGURA 11 Exemplos de infográficos analisados: Política Tarifária e Aprenda a $\quad \mathbf{6 5}$ Economizar Água.

FIGURA 12 Exemplos de infográficos analisados: Mulheres na Política e Ciclo da Dengue.

FIGURA 13 Exemplo de estrutura com linguagem da célula 28 (Não linear não $\mathbf{6 6}$ direcionado e Esquemático).

FIGURA 14 Exemplo de detalhamento com linguagem da célula 13 (Não linear direcionado e Pictórico \& Verbal/numérico).

FIGURA 15 Detalhes de infográfico analisado, Aprenda a Economizar Água, com exemplo de uso dos métodos de configuração de listas (à esquerda) e não linear direcionado.

FIGURA 16 Detalhes de infográficos analisados, Famílias Chefiadas por Mulheres e Economia de Energia, com exemplo de uso dos modos de simbolização Verbal/numérico, Pictórico, e Esquemático.

FIGURA 17 Parte do modelo de linguagens de Twyman (1985), adaptado e traduzido. 


\section{Lista de tabelas}

TABELA 1 Sites do governo executivo federal que continham a palavra infográfico $\mathbf{1 4}$ em maio de 2015.

TABELA 2 Estágios do processo de Sless (2008), adaptado e traduzido.

TABELA 3 Fases e etapas do processo de Carvalho e Aragão (2012), adaptado.

TABELA 4 Processo de Kanno (2013), adaptado.

TABELA 5 Comparação de processos com fases e atividades.

TABELA 6 Fases e atividades propostas para efeito comparativo.

TABELA 7 Formação acadêmica dos entrevistados.

TABELA 8 Vínculo com o governo. $\quad 44$

TABELA 9 Comparação da tabela proposta com as respostas dos infografistas. $\quad \mathbf{5 5}$

TABELA 10 Matriz de Twyman (1979), adaptada e traduzida. 59

TABELA 11 Infográficos componentes da amostra da pesquisa. 63

TABELA 12 Matrizes adaptadas com as marcações de estrutura e detalhamento. $\quad 68$

TABELA 13 Proposta de tabela modificada, a partir da matriz de Twyman (1979), 71 acrescentando duas linhas e indicação da marcação de ênfase.

TABELA 14 Lista de recomendações resumida. 


\section{Sumário}

INTRODUÇÃO ............................................................................................................................. 12

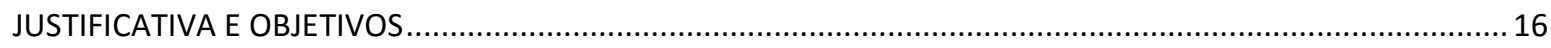

ESTRUTURA DO TRABALHO ......................................................................................................... 17

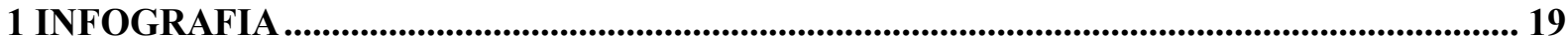

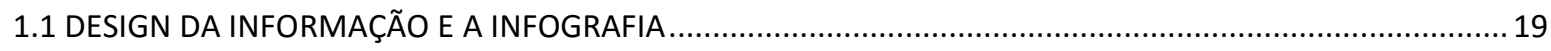

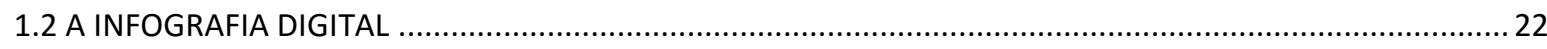

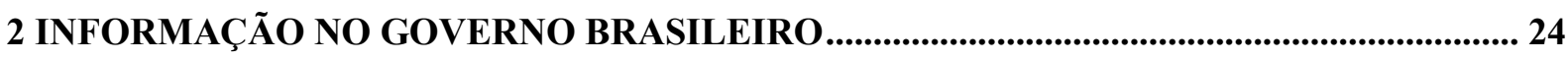

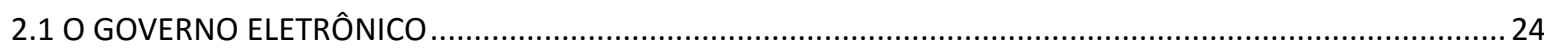

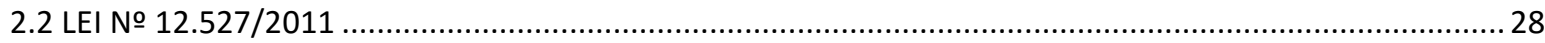

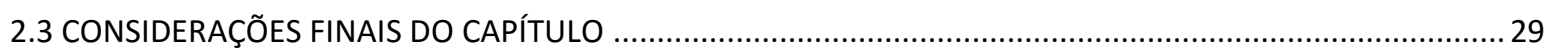

3 PROCESSO DE ELABORAÇÃO DE INFOGRÁFICOS......................................................... 31

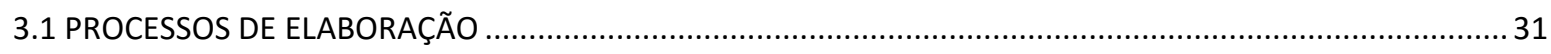

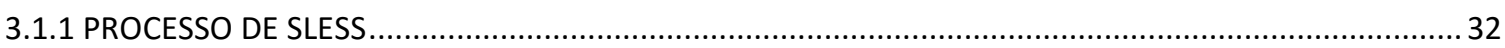

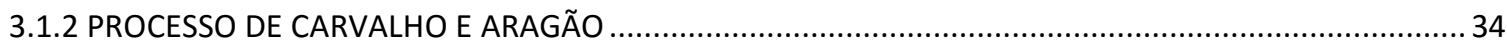

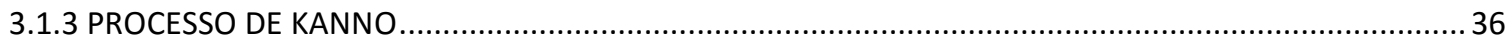

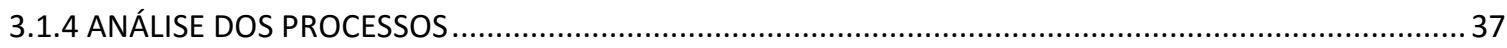

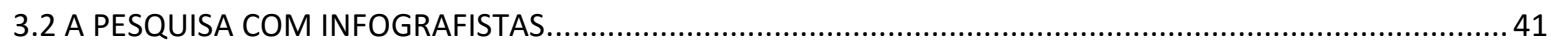

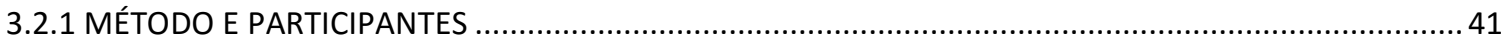

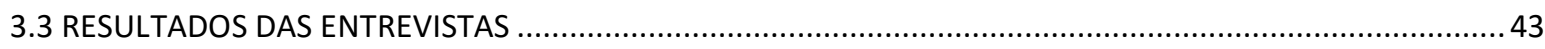

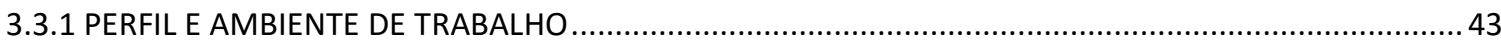

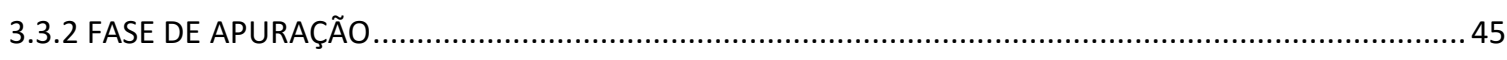

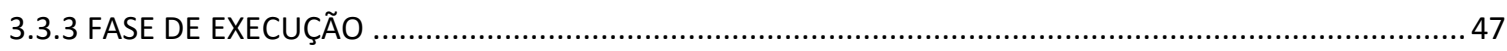

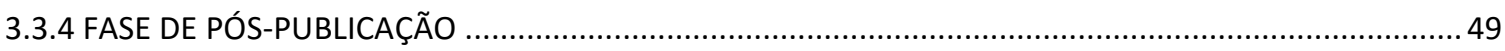

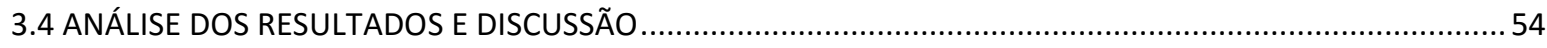

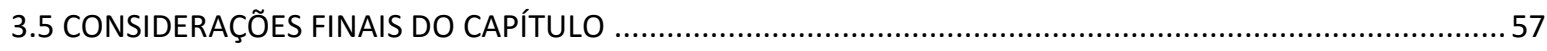

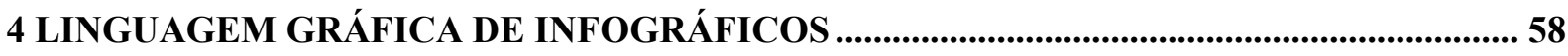

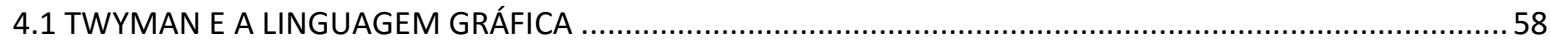

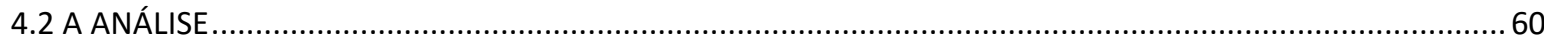

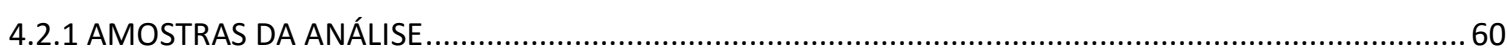

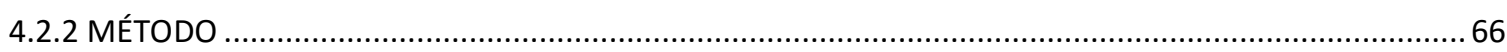

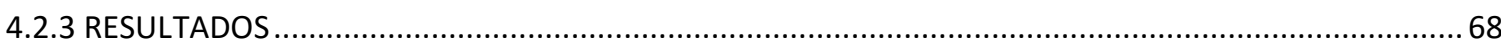

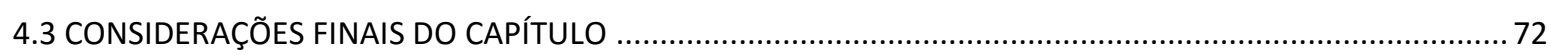

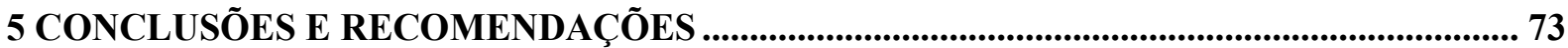




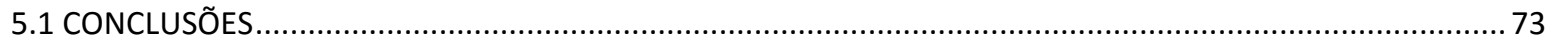

5.1.1 QUAIS OS PROCESSOS DE ELABORAÇÃO DE INFOGRÁFICOS DIGITAIS NO GOVERNO? .................... 74

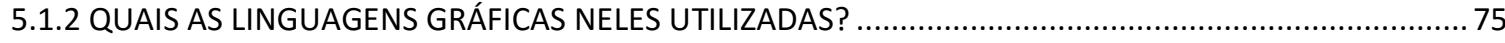

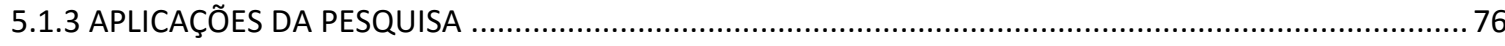

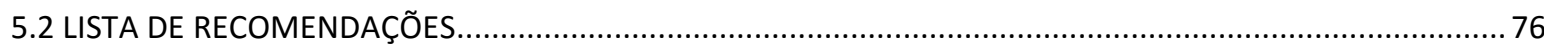

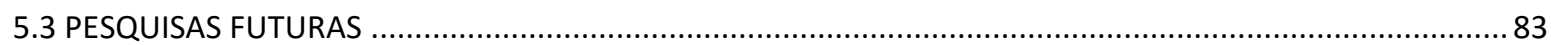

REFERÊNCIAS BIBLIOGRÁFICAS ........................................................................................8 84

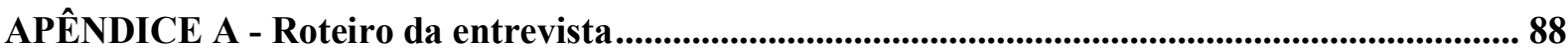

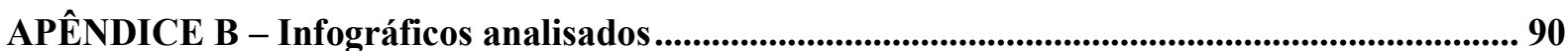




\section{INTRODUÇÃO}

É inegável a enorme quantidade de informações disponíveis na web nos dias de hoje. O resultado de uma pesquisa em um site de busca pode retornar centenas ou até milhares de registros, que levam a páginas com conteúdos diversos, quais sejam convergentes ou divergentes, claros ou imprecisos, fidedignos ou duvidosos. Segundo Barreto (2010), vivemos agora os efeitos de uma explosão informacional, na qual a quantidade de informação multiplica-se em progressão geométrica pelo aumento do uso do computador, da televisão e da internet.

Diante da explosão informacional em progressão, pode-se deduzir que seja uma tarefa árdua para o ser humano absorver todo o conteúdo resultante de uma pesquisa em um site de busca. Vê-se na figura abaixo que uma pesquisa pelo termo "Design" no Google ${ }^{1}$ retornou em menos de um segundo mais de quatro bilhões de registros:

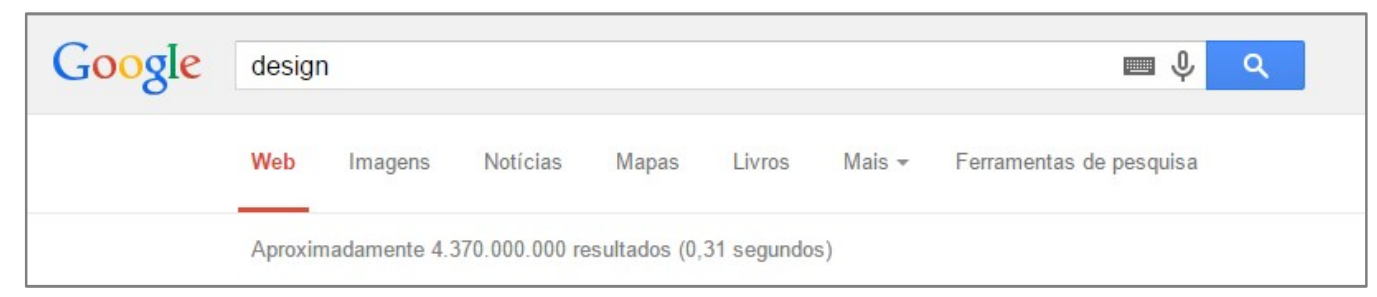

Figura 1: Busca pelo termo Design no Google, em maio de 2015.

Dessa forma, os usuários que pesquisam informações na internet selecionam, dentre as opções, as que lhes parecem mais adequadas, de acordo com seus critérios de escolha. No novo estilo de vida na era digital, dados e informações precisam ser de processamento mais fácil e rápido. As pessoas procuram por títulos e gráficos que atraem seu interesse e gastam menos tempo considerando se a leitura vale ou não a pena (SIRICHAROEN, 2013). A forma pela qual os conteúdos informativos são representados na internet é diversificada: textos combinados ou não com links, tabelas e imagens. Porém, nem sempre essas apresentações são suficientes para auxiliar o usuário a interpretar o conteúdo informativo da forma esperada. Segundo Santos (2002), com as facilidades da mídia digital é

\footnotetext{
${ }^{1}$ Site de busca na internet. www.google.com.br
} 
cada vez maior a quantidade de interfaces geradas para sistemas informatizados, porém, o resultado final pode não ser adequado ou não atingir plenamente suas metas de uso.

Para a obtenção dessas metas de uso, alguns sistemas informatizados passaram a valer-se de ferramentas de visualização. Para Ribeiro (2009), compreender dados numéricos em uma tabela é uma tarefa possível para um ser humano, mas quando construímos gráficos a partir da seleção desses dados, a interpretação da informação, até então oculta nas entrelinhas, fica muito mais clara e evidente. Esse seria o princípio explorado pelas ferramentas de visualização: evidenciar relacionamentos presentes num universo de dados. A visualização se constituiria como instrumento fundamental para revelar sentidos ocultos, invisíveis numa observação restrita aos dados em si.

A fim de evidenciar esses relacionamentos presentes num universo de dados e de deixar a informação mais clara e evidente, está presente a disciplina do design da informação, área de atividade ligada à infografia, conforme explicitado no desenvolvimento desta dissertação.

Ultimamente, a infografia tem conquistado seu espaço nos sites do governo brasileiro como tipo de visualização de informação digital, em especial após a publicação da Lei de Acesso a Informações $n^{0} 12.527 / 2011$, que regulamenta o direito constitucional do acesso dos cidadãos às informações públicas.

Com a Lei de Acesso à Informação, a regra geral é a de que as informações produzidas pela Administração Pública sejam acessadas por qualquer pessoa. Para que o cidadão possa usar a informação a que tem acesso, é preciso que ela possa ser compreendida. Para isso, os órgãos e entidades públicas devem se esforçar continuamente para aprimorar sua comunicação com a sociedade e para divulgar as informações em uma linguagem acessível.

De forma a confirmar a existência do objeto de análise (infográficos de sites de órgãos governamentais brasileiros), constituiu-se uma pesquisa em sites do Poder Executivo Federal. O Poder Executivo no Brasil era composto, à época da pesquisa, por 24 ministérios, nove secretarias da presidência com status de ministério e cinco órgãos com status de ministério.

A pesquisa foi efetuada nos sites dos 24 ministérios, nos cinco órgãos com status de ministério, e também no site Portal Brasil e no Blog do Planalto ${ }^{2}$. O Portal Brasil foi inserido na pesquisa por ser o meio digital de convergência de canais e integração dos órgãos do Poder Executivo Federal, sendo considerado o portal de entrada do governo brasileiro. Sob

\footnotetext{
${ }^{2}$ Disponível em http://blog.planalto.gov.br, acesso em março 2015.
} 
a responsabilidade da Secretaria de Comunicação Social da Presidência da República $(\text { Secom })^{3}$, que tem como premissa orientar a comunicação governamental de todos os órgãos do Poder Executivo na internet por meio da Identidade Digital Padrão do Governo Federal, o site foi criado com o objetivo de facilitar a comunicação governamental entre o Estado e a opinião pública. O Portal do Planalto, por sua vez, foi considerado por ser a fonte de divulgação, em formato multimídia, das políticas públicas que buscam aproximar o governo federal dos cidadãos. Nele é possível pesquisar discursos e entrevistas em texto, áudio e vídeo, fotos dos compromissos presidenciais, biografias e cobertura de cerimônias conduzidas pela presidente.

A averiguação foi efetuada digitando a palavra-chave "infográfico" nos mecanismos de busca encontrados nas páginas iniciais dos seus portais. Na Tabela 1 pode-se ver a lista dos sites e o respectivo quantitativo de registros, em ordem decrescente da quantidade de registros:

\begin{tabular}{|c|c|}
\hline NOME DO SITE & $\begin{array}{l}\text { QUANTIDADE DE } \\
\text { REGISTROS }\end{array}$ \\
\hline Portal Brasil & 218 \\
\hline Ministério do Planejamento, Orçamento e Gestão & 18 \\
\hline Portal do Planalto & 17 \\
\hline Ministério do Desenvolvimento Social e Combate à Fome & 17 \\
\hline Ministério das Comunicações & 16 \\
\hline Ministério da Defesa & 15 \\
\hline Ministério da Justiça & 11 \\
\hline Banco Central & 9 \\
\hline Ministério do Esporte & 8 \\
\hline Ministério da Ciência e Tecnologia & 5 \\
\hline Controladoria-Geral da União & 4 \\
\hline Ministério do Turismo & 4 \\
\hline Ministério da Integração Nacional & 3 \\
\hline
\end{tabular}

\footnotetext{
${ }^{3}$ Disponível em http://www.secom.gov.br, acesso em março 2015.
} 


\begin{tabular}{|l|l|}
\hline Ministério da Educação & 1 \\
\hline Ministério do Meio Ambiente & 1 \\
\hline Ministério da Saúde & 1 \\
\hline Casa Civil & 1 \\
\hline
\end{tabular}

Tabela 1: Sites do governo executivo federal que continham a palavra infográfico em maio de 2015.

A Figura 2 apresenta um exemplo de infográfico publicado em site de um órgão do governo brasileiro:

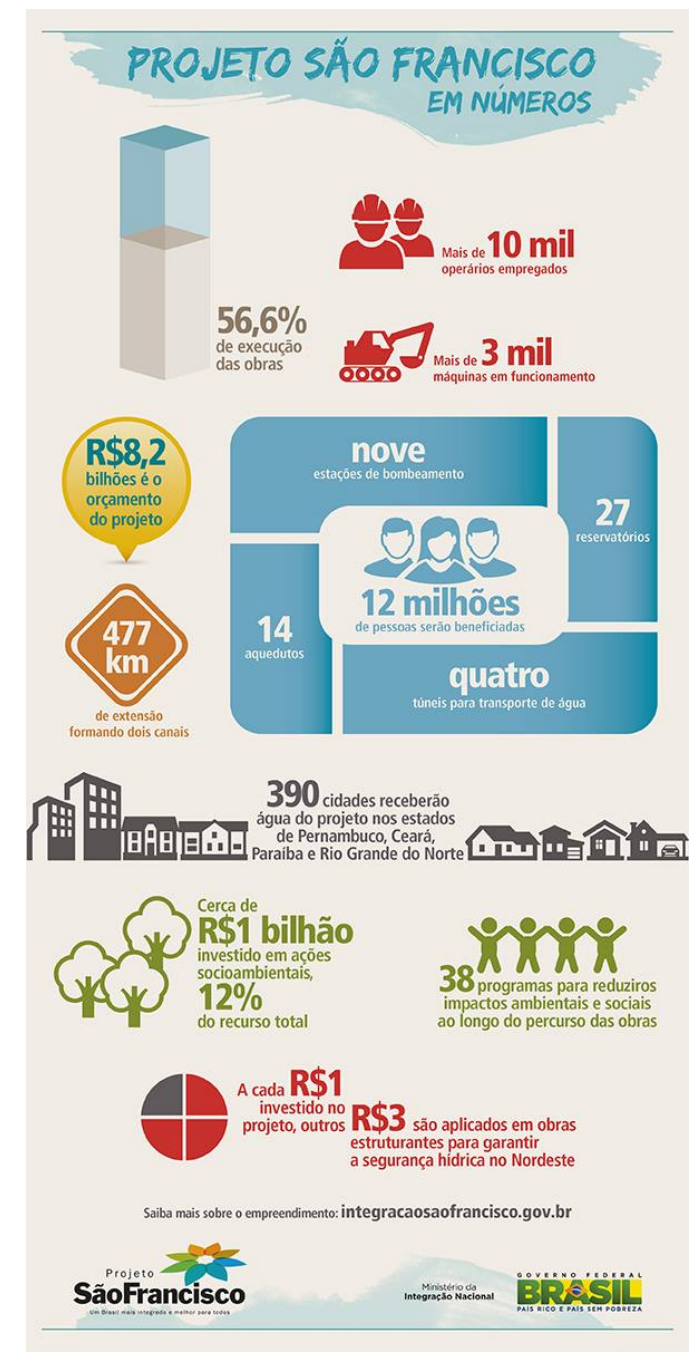

Figura 2: Exemplo de infográfico no governo brasileiro ${ }^{4}$

\footnotetext{
${ }^{4}$ Infográfico sobre a integração do Rio São Francisco, do Ministério da Integração Nacional, publicado em julho de 2014 no Portal Brasil. Disponível em http://www.brasil.gov.br/infraestrutura/2014/05/integracao-do-saofrancisco-contempla-12-milhoes-de-pessoas, acessado em janeiro de 2015.
} 
Pela presença de centenas de registros nos sites, percebe-se que o uso dos infográficos em sites governamentais já está sendo colocado em prática. Além dessa constatação, em muitos sites foram encontrados infográficos publicados, mesmo sem o registro da palavra infográfico no seu conteúdo.

\section{JUSTIFICATIVA E OBJETIVOS}

Não obstante os numerosos estudos sobre infográficos digitais e jornalísticos, não foram encontrados estudos na literatura sobre os infográficos em sites do governo brasileiro. Não são conhecidos os processos sob os quais esses infográficos são elaborados e quais as ferramentas visuais empregadas em suas soluções, fatores cujas relevâncias estão descritas a seguir.

Os processos de elaboração são relevantes, visto que eles levam o designer até o produto final. Além disso, a velocidade e o dinamismo atuais configuram um momento que destaca a necessidade de nova abordagem de projeto, processo e produção adequados ao contexto atual (VIEIRA, 2007). Ainda de acordo com o autor, é flagrante a importância de metodologias de design que suportem a complexidade e apoiem o desenvolvimento ágil, eficiente e efetivo de novos produtos. Os infográficos mostram-se produtos novos em site de governo e seu processo de elaboração na esfera governamental é desconhecida.

As linguagens gráficas também são relevantes, visto que elas devem ser o foco do designer que objetiva comunicar a mensagem de forma eficiente (TWYMAN, 1979).

Isto posto, as questões que fomentaram este estudo foram: (a) quais os processos de elaboração de infográficos digitais no governo? e (b) quais as linguagens gráficas neles utilizadas?

Para responder estas questões, foram realizados dois estudos. O primeiro estudo refere-se a uma análise de processos de elaboração disponíveis na literatura e uma pesquisa com profissionais que elaboram infográficos para órgãos governamentais, a fim de conhecer os seus processos de elaboração e compará-los com os processos teóricos. O segundo estudo é uma análise da linguagem gráfica de infográficos encontrados em sites do governo brasileiro, situando-os em uma matriz que compreende modos de simbolização e métodos de configuração (TWYMAN, 1979). 
Ao final do estudo é relatada uma lista de recomendações sobre processos de elaboração e linguagem gráfica, que tem como objetivo auxiliar o governo e os infografistas na elaboração dos infográficos de informação pública oficial.

\section{ESTRUTURA DO TRABALHO}

No primeiro capítulo desta dissertação apresenta-se um levantamento teórico acerca do design da informação e sua relação com infográficos e uma revisão da literatura que passeia pelos conceitos de design da informação, infografia e infografia digital.

No segundo capítulo trata-se das questões do governo brasileiro quanto ao governo eletrônico, como um veículo para o ciclo de prestação de informações com o uso da tecnologia da informação nos níveis da Administração Pública, descrevendo as premissas e diretrizes existentes em manuais e cartilhas de boas práticas na área digital e a Lei de Acesso a Informações, $n^{\circ} 12.527 / 2011$ e contextualizando o meio no qual os infográficos estudados nesta pesquisa estão inseridos.

O terceiro capítulo inicia-se com uma descrição de processos de elaboração de infográficos disponíveis na literatura (SLESS, 2008; CARVALHO E ARAGÃO, 2012; KANNO, 2013) e segue para uma análise dos processos. Em seguida é apresentado um estudo com base em entrevistas com doze profissionais que elaboram infográficos para órgãos governamentais brasileiros, a fim de conhecer seus processos de trabalho. Os resultados das entrevistas são comparados com os processos de elaboração analisados.

O quarto capítulo apresenta uma análise das propriedades formais de vinte infográficos encontrados em sites do governo federal brasileiro, publicados de 2010 a 2014 no Portal Brasil. A análise considera como base a classificação descrita por Twyman (1979), que compreende os métodos de configuração e os modos de simbolização da linguagem gráfica em uma matriz. O intuito dessa análise é apontar métodos e modos encontrados nos infográficos de sites do governo federal brasileiro, identificando particularidades, similaridades e diferenças nas linguagens.

O quinto capítulo traz as conclusões obtidas a partir dos resultados das entrevistas com infografistas sobre processos de elaboração e dos resultados da análise de linguagem gráfica. O capítulo traz também as respostas das duas questões que motivaram a pesquisa e as aplicações dos resultados. 
As fases descritas nos capítulos desta dissertação contribuíram para a produção de uma lista de recomendações para o governo e para infografistas. O objetivo da lista de recomendações é servir de apoio para que os processos de elaboração de infográficos de informações governamentais públicas possam ser aprimorados, e para que as representações gráficas utilizadas sejam adequadas aos seus propósitos.

Finaliza-se a pesquisa com as discussões e caminhos futuros a serem percorridos. 


\section{INFOGRAFIA}

Este capítulo apresenta um levantamento teórico acerca do design da informação e sua relação com infográficos. Nele é descrito um breve histórico da infografia, além de uma revisão da literatura que passeia pelos conceitos de design da informação, infografia e infografia digital. Não se pretende trazer uma discussão conceitual, mas sim evidenciar os conceitos utilizados na pesquisa.

\subsection{DESIGN DA INFORMAÇÃO E A INFOGRAFIA}

A função de deixar a informação mais clara e de evidenciar relacionamentos presentes num universo de dados percebe-se envolvida em diversas áreas como a comunicação, a educação, a psicologia e o design da informação. O foco deste estudo concentra-se no design da informação, considerando as seguintes definições: design é a identificação de um problema e o esforço criativo e intelectual de alguém que manifesta-se em desenhos ou planos que incluem esquemas e especificações (IIID, 2000); e informação é o resultado do processamento, manipulação e organização de dados de forma que contribua para o conhecimento da pessoa que a recebe (IDX, 2007).

Assim, o design da informação é a “definição, planejamento e modelagem do conteúdo de uma mensagem e dos ambientes em que é apresentado, com a intenção de satisfazer as necessidades de informação dos destinatários" (IDX, 2007).

Com conceitos diversos na literatura, o design da informação é definido também como a arte e a ciência de preparar a informação para que esta seja usada por pessoas com eficiência e eficácia (HORN e JACOBSON, 1999). Para os autores, os objetivos primários do design da informação são desenvolver documentos que sejam compreensíveis, de recuperação rápida e apurada, e fácil de colocar em prática. A eficiência e a eficácia em concluir o propósito comunicativo seriam duas premissas da disciplina. Para Jacobson (1999), o design da informação é o arranjo sistemático e o uso dos elementos de comunicação para transmitir significado e aumentar entendimento entre as partes. Ele frisa que o designer de informação tem uma responsabilidade moral, mencionando Horn (1999) e o poder interpretativo do profissional na missão de elucidar e clarear o sentido das coisas. Para Visocky O'Grady (2008), nesse mundo complexo da era da informação, os designers de informação são os 
bravos a apresentar os documentos às massas. Já Tufte (1990) acredita na universalização do design da informação, pois para ele os princípios do design da informação não estariam atrelados a particularidades únicas de linguagem ou cultura, eles seriam universais, assim como a matemática. Segundo o autor, a excelência gráfica é o que garantiria o entendimento universal das visualizações de informação impressas. Segundo a SBDI, Sociedade Brasileira de Design da Informação (2010), o princípio básico da disciplina é "otimizar o processo de aquisição da informação efetivado nos sistemas de comunicação analógicos e digitais".

Com relação ao objetivo do design da informação, Frascara (2011) o percebe com a função de assegurar a efetividade da comunicação por meio da facilitação dos processos de percepção, leitura, compreensão, memorização e uso da informação apresentada. O design da informação propicia que dados e informações sejam representados a fim de um processamento mais fácil e rápido.

Em seu livro Design for Information, Meirelles (2013) percebe a necessidade de conceituar "infográficos" e "design da informação", termos utilizados por profissionais da área do design para referirem-se a representações visuais da informação. Para a autora, infográficos são representações visuais em que gráficos (e.g. ilustrações, símbolos, mapas, diagramas, etc.), em conjunto com linguagem verbal, comunicam informações que não seria possível transmitir de outra forma. Utilizados no jornalismo e em livros pedagógicos e técnicos, os infográficos explicam funcionamentos, explicam temas complexos e contam histórias, como representações tão diversas como mapas climáticos, partes do corpo humano, o funcionamento do cérebro ou mesmo mapas do metrô.

Já o design da informação, para a autora, é usado para descrever práticas do design da comunicação em que o propósito maior é de informar, em contraste a abordagens mais persuasivas mais usadas na publicidade. Infográficos seriam um dos tipos de artefatos utilizados pelo design da informação, assim como sistemas de informação e visualização de dados estatísticos. Todas essas representações partilhariam do objetivo comum que é o de revelar padrões e relacionamentos desconhecidos ou não tão perceptíveis sem a ajuda da representação visual da informação.

Temos disposto então que o design da informação percebe-se como uma área de atividade intimamente ligada com a infografia e a visualização da informação (FASSINA, 2011).

Os indícios das primeiras infografias remetem aos veículos impressos nos jornais do século XVII, na Europa e Estados Unidos (SANCHO, 2001). Em 1991, depois da Guerra 
do Golfo, os infográficos foram integrados como mecanismo de comunicação visual na mídia impressa e televisiva.

No Brasil, a partir dos anos 90, revistas e jornais (e.g. Editora Abril, O Dia, O Globo e Folha de S. Paulo) começaram a fazer uso de infográficos no jornalismo impresso. Na Figura 3 pode-se ver um infográfico de 1998 publicado em revista brasileira:

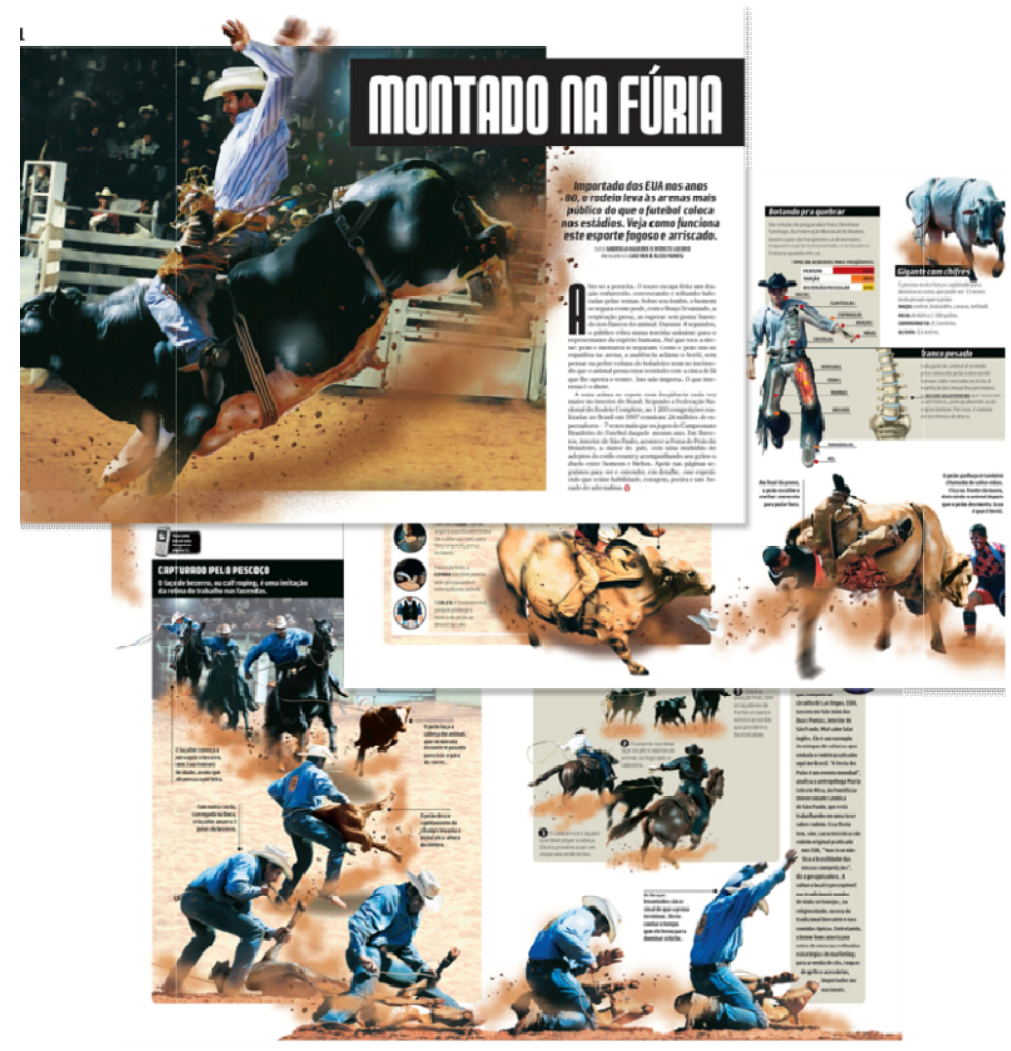

Figura 3: Exemplo de infográfico jornalístico dos anos $90^{5}$.

Todavia, as definições e conceitos aplicados à infografia, que vem do inglês informational graphics, são amplos e diversos. Muitos autores definem infográficos com diferentes abordagens. Por exemplo, de forma mais generalizada, Cairo (2008:21) define infográfico como a "representação diagramática de dados", sendo diagramas as representações abstratas da realidade. Todavia, Moraes (1998:68) descreve infografia de forma específica como sendo o "registro gráfico da informação, pela combinação de linguagens verbal e iconográfica, com certo predomínio desta última”. Já Lima (2009:23), a

\footnotetext{
5 "Montado na Fúria”, série de infográficos da Revista SuperInteressante publicados em 1998, por Luiz Iria e Alceu Chiesorin Nunes. Disponível em http://visualoop.com/blog/11928/talking-with-luiz-iria, acessado em dezembro 2014.
} 
partir de revisão literária sobre definições de infográfico, afirma que se costuma definir infografia como uma "peça gráfica que utiliza simultaneamente a linguagem verbal gráfica, esquemática e pictórica, voltada prioritariamente à explicação de algum fenômeno”. O autor propõe uma definição de infografia jornalística como uma interdependência de texto e iconografia:

Tipo de matéria jornalística onde o texto e iconografia são interdependentes e a estratégia de leitura pode se desenvolver de forma não-linear, que se diferencia da iconografia tradicional pela possibilidade de se comportar como a fonte principal de informação na página." (LIMA, 2009:26)

Ainda no contexto do jornalismo, Teixeira (2007:112) explica que a infografia é "um recurso que alia imagem e texto de modo complementar para passar alguma(s) informação(ões)", sendo este o conceito considerado neste estudo.

O recurso da infografia extrapolou as páginas impressas e tomou seu lugar no ciberespaço, como descrito a seguir com o conceito de infografia digital.

\subsection{A INFOGRAFIA DIGITAL}

De forma inovadora e com grande apelo, os infográficos conquistaram seu espaço nas interfaces web. Neste estudo, esses infográficos são chamados de "infográficos online" ou “infográficos digitais". Conforme descreveu Andrade (2014), a infografia online é referida na literatura por diversos termos: infografia digital, infografia interativa, infografia multimídia, dentre outros. As nomenclaturas tratam do mesmo assunto e não excluem a manifestação de outras formas de infografia no ambiente digital. A Figura 4 apresenta um infográfico digital, publicado online em um site de notícias: 


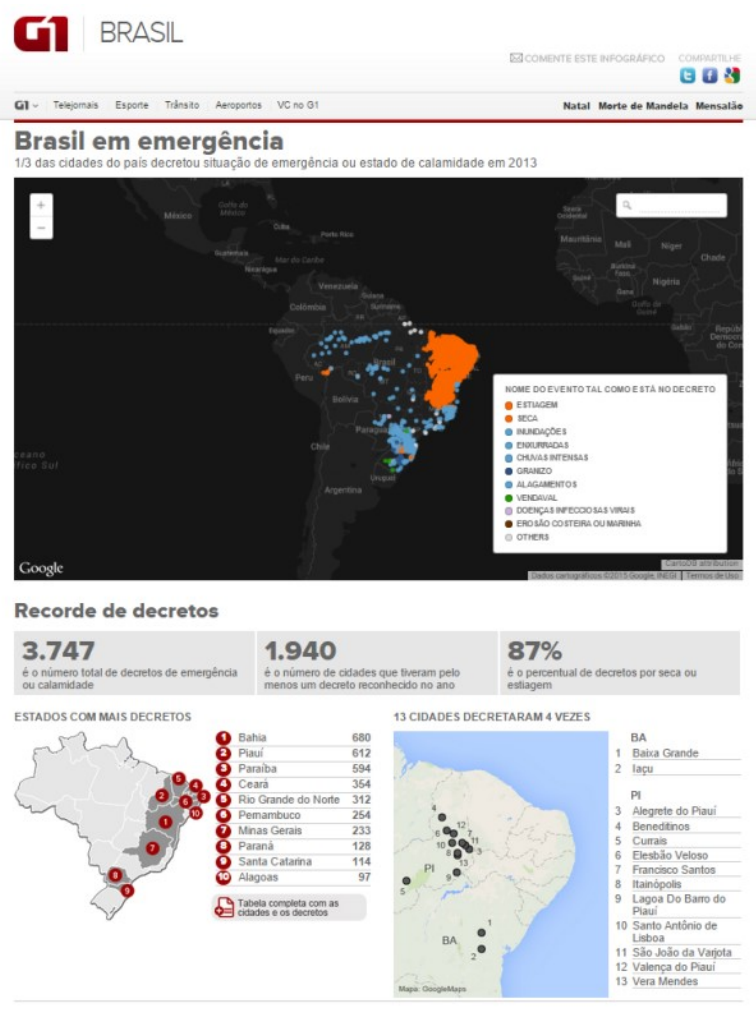

Figura 4: Exemplo de infográfico digital ${ }^{6}$.

Segundo Andrade (2014), o termo “digital” traz uma série de expectativas a respeito do potencial da infografia naquele ambiente, o que leva autores como Cairo (2004) a considerá-la uma ferramenta de exploração de informação, propiciando um aumento da experiência do usuário, favorecendo a imersão e compreensão do conteúdo. $\mathrm{O}$ autor relata, porém, que em alguns casos os infográficos são publicados de forma estática no hipertexto, sem contar com as apresentações dinâmicas como animação e interatividade, que se utilizam do potencial oferecido pelos recursos do ambiente digital. Similar a Teixeira (2007), Souto (2014:1.234) define infográfico online como "gráficos digitais que representam visualmente uma informação". Sendo o foco deste estudo infográficos online ou digitais, esta última definição é utilizada.

Como este estudo dedica-se a analisar os infográficos digitais no contexto do governo brasileiro, o próximo capítulo tratará das especificidades do governo quanto ao acesso à informação.

6 "Brasil em Emergência", infográfico publicado no site do jornal G1. Disponível em http://g1.globo.com/brasil/pais-emergencia-2013/infografico/platb/, acessado em março 2015. 


\section{INFORMAÇÃO NO GOVERNO BRASILEIRO}

São apresentadas neste capítulo explanações quanto ao Governo Eletrônico como veículo de prestação de informações nos níveis da Administração Pública e quanto aos pontos da Lei de Acesso à Informação, Lei $n^{0}$ 12.527/2011, que tratam de acesso às informações públicas. Este estudo tem como objetivo observar quais premissas devem ser consideradas na elaboração de infográficos em sites do governo brasileiro.

\subsection{O GOVERNO ELETRÔNICO}

O Governo Eletrônico ${ }^{7}$ (GOV.BR) surgiu no ano 2000, quando foi criado um Grupo de Trabalho Interministerial com a finalidade de examinar e propor políticas, diretrizes e normas relacionadas às novas formas eletrônicas de interação, através do Decreto Presidencial de 3 de abril de 2000. O Governo Eletrônico é um tema atual, em especial por meio de portais e serviços eletrônicos (RIECKEN, 2010). Os potenciais benefícios do Governo Eletrônico são, de acordo com Dias (2006), a prestação de melhores serviços, conveniência, economia de tempo, qualidade, confiabilidade, usabilidade e variedade de canais de atendimento. Os programas de Governo Eletrônico têm como princípio a utilização das Tecnologias de Informação e Comunicação (TICs) para democratizar o acesso à informação, ampliar discussões e dinamizar a prestação de serviços públicos com foco na eficiência e efetividade das funções governamentais. Pretende-se com o Programa de Governo Eletrônico brasileiro transformar as relações do governo com os cidadãos, de forma a fortalecer a participação cidadã por meio do acesso a informação, dentre outros.

Para garantir o acesso facilitado às informações digitais, foi criado o projeto de Identidade Digital de Governo, que conta com cartilhas de codificação, administração, usabilidade e redação web. A seguir seguem descrições sobre o projeto de Identidade Digital de Governo e sobre a Cartilha de Usabilidade.

\footnotetext{
${ }^{7}$ Disponível em http://www.governoeletronico.gov.br, acessado em março 2015.
} 
O projeto de Identidade Digital de Governo ${ }^{8}$ foi criado para garantir o acesso facilitado às informações digitais do governo, padronizando os portais dos órgãos públicos federais e alinhando as informações disponíveis. A Identidade Digital do Poder Executivo Federal é um conjunto de diretrizes, orientações, padrões e modelos a serem aplicados em elementos que compõem a Identidade Digital como a barra de governo, portais institucionais, sítios temáticos, informativo, redes sociais, guia de serviços, guia de aplicativos e outras ferramentas digitais. $\mathrm{O}$ objetivo da adoção da identidade digital é qualificar a comunicação do governo com a sociedade em ambientes digitais; padronizar as propriedades digitais do Poder Executivo federal; facilitar o acesso da população às informações de interesse público e sobre as políticas públicas; integrar as plataformas digitais do governo; e imprimir mais credibilidade às informações disponíveis. É obrigatória a adoção por órgãos e entidades da Administração Federal que mantenham ou venham a manter sítios ou portais nos domínios do Poder Executivo federal, perfis nas redes sociais, aplicativos e demais propriedades digitais.

O projeto considera uma área específica para a publicação de infográficos, em um menu lateral chamado de Centrais de Conteúdo, como pode ser visto na Figura 5.

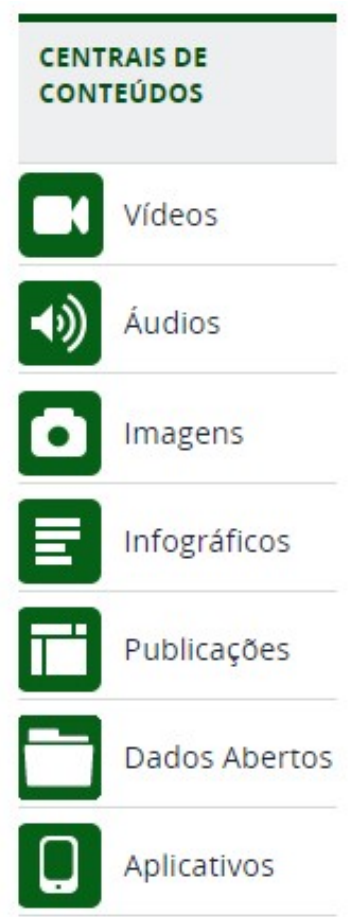

Figura 5: Área de Centrais de Conteúdo o Portal Padrão ${ }^{9}$.

\footnotetext{
${ }^{8}$ Disponível em http://governoeletronico.gov.br/acoes-e-projetos/identidade-digital-do-governo, acessado em março 2015.

${ }^{9}$ Disponível em HTTP://www.portalpadrao.gov.br, acessado em março 2015.
} 
O menu conta com links que levam para páginas específicas com publicações de conteúdos diversos.

Ao acessar o link de infográficos, uma página dedicada somente a eles é mostrada, com áreas de destaques e um link para a lista completa de infográficos, como mostra a Figura 6. Cada infográfico deve ter um título e um subtítulo.

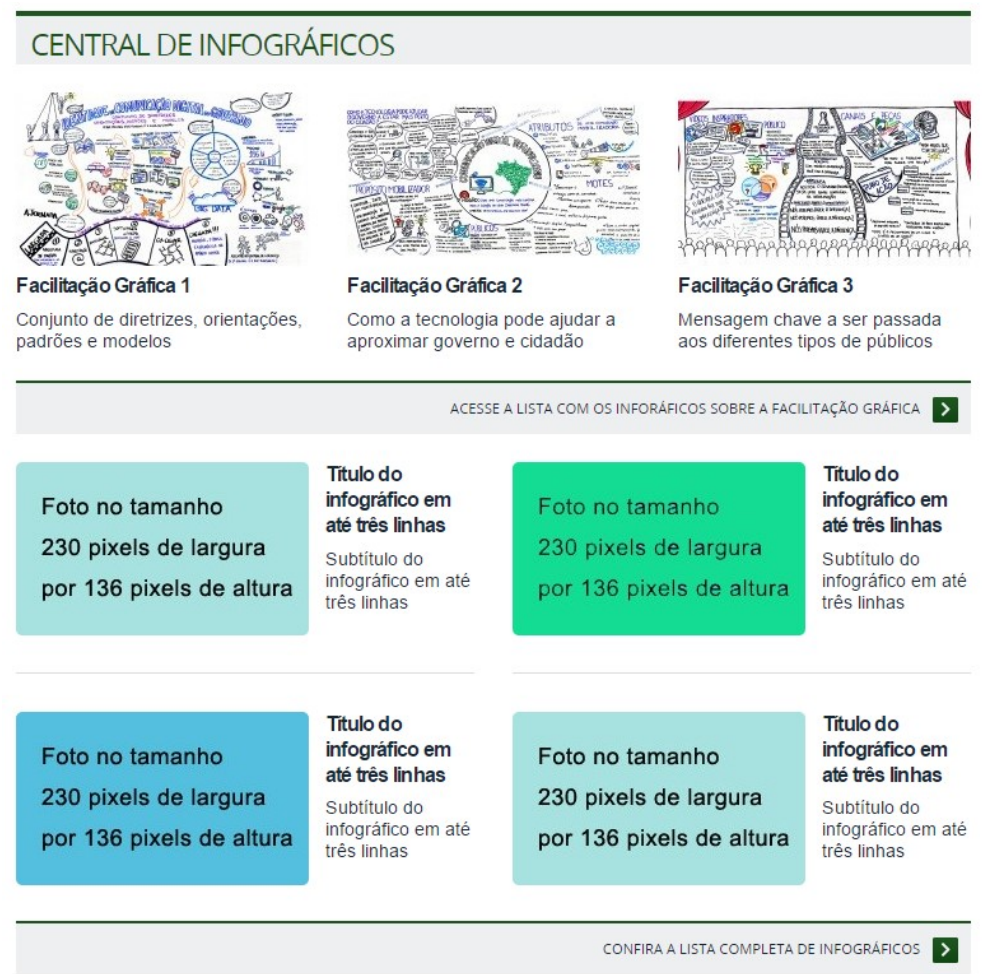

Figura 6: Página de central de Infográficos da Identidade Digital do Governo.

De acordo com o padrão da identidade digital, notícias, infográficos, imagens, áudios e vídeos publicados nos sites de órgãos públicos federais devem ter, obrigatoriamente, dois vocábulos controlados cadastrados. Os Infográficos incorporados às notícias têm altura liberada, mas devem respeitar a largura da área de conteúdo, sendo:

- 750 pixels de largura (quando o grid for composto por coluna de menus + área de conteúdo);

- 490 pixels de largura (quando o grid for composto por coluna de menus + área de conteúdo + coluna à direita). 
O projeto de Identidade Digital de Governo conta com manuais ${ }^{10}$ que auxiliam durante a montagem de sítios dos órgãos do governo federal, e, dentre os manuais estão o "Guia de Estilo de Sítios e Portais da Identidade Padrão da Comunicação Digital do Governo Federal", o "e-MAG - Modelo de Acessibilidade de Governo Eletrônico"11 e o "ePWG Padrões $W e b$ em Governo Eletrônico"12.

O "e-MAG - Modelo de Acessibilidade de Governo Eletrônico" tem o objetivo de ser o norteador no desenvolvimento e na adaptação de conteúdos digitais do governo federal, garantindo o acesso a todos. Ele teve sua primeira versão publicada em 2005 e desde então conta com diversas atualizações. O documento descreve o processo para o desenvolvimento da acessibilidade à $w e b$, para garantir acesso facilitado a qualquer pessoa, independente das condições físicas, dos meios técnicos ou dispositivos utilizados. O processo para desenvolver um sítio acessível é realizado em três passos:

1. Seguir os padrões web;

2. Seguir as diretrizes ou recomendações de acessibilidade; e

3. Realizar a avaliação de acessibilidade.

No modelo, é recomendado que seja fornecida alternativa em texto para todas as imagens de um sítio, com a descrição das imagens da página adaptadas ao contexto em que as imagens se encontram.

Para imagens mais complexas que exigem uma descrição mais detalhada, como infográficos, por exemplo, deve-se fornecer, a descrição no próprio contexto ou um link para a descrição longa logo após a imagem. Deve ficar claro para o usuário que esse link remete para a descrição longa da imagem.

O "ePWG - Padrões Web em Governo Eletrônico" conta com cartilhas de codificação, administração, usabilidade e redação web. A Cartilha de Usabilidade do Projeto Padrões Web em Governo Eletrônico - e-PWG, do Programa de Governo Eletrônico do Governo Federal fornece recomendações de boas práticas na área digital, com o objetivo de aprimorar a comunicação, o fornecimento de informações e serviços prestados por meios eletrônicos pelos órgãos do governo federal. Ela tem por objetivo apresentar a usabilidade, inserindo-a no contexto do desenvolvimento e manutenção de sítios de governo eletrônico, como se pode confirmar em trecho da cartilha:

\footnotetext{
10 Disponível em http://governoeletronico.gov.br/acoes-e-projetos/identidade-digital-do-governo/manuais, acessado em março 2015.

${ }^{11}$ Disponível em http://emag.governoeletronico.gov.br/, acessado em março 2015.

12 Disponível em http://governoeletronico.gov.br/acoes-e-projetos/identidade-digital-do-governo/acoes-eprojetos/padroes-brasil-e-gov, acessado em março 2015.
} 
"Para a usabilidade, o ponto de partida do desenvolvimento é o usuário. Usuário é o termo técnico utilizado em usabilidade para referir-se a cada pessoa que utiliza o objeto em questão por meio de uma interface. No caso temos o cidadão como usuário e o objeto são as páginas, informações e serviços disponibilizados eletronicamente pelo governo federal." (CARTILHA DE USABILIDADE - EPWG, 2010).

A cartilha possui recomendações e subsídios para testes de usabilidade. Ainda segundo a cartilha é necessário conhecer, entender e trabalhar com as pessoas que representam os atuais e potenciais utilizadores do produto e saber o contexto da utilização, ou seja, de onde o cidadão acessa, em que ambiente e em que condições.

Segundo Kafure (2004), usabilidade "é a capacidade que a imagem da Interação Homem-Computador oferece para a recuperação da informação por parte de usuários, de maneira eficaz, eficiente e a satisfatória". Santos (2002) afirma que a "usabilidade pode ser compreendida como a capacidade, em termos funcionais humanos, de um sistema ser usado facilmente e com eficiência pelo usuário". Os fatores relacionados ao termo usabilidade seriam, dentre outros: a facilidade de aprendizagem, a efetividade, adequação à tarefa e características dos usuários.

Confirma-se, dessa forma, a intenção do governo de garantir a usabilidade de informações disponibilizados eletronicamente pelo governo federal. Para regulamentar essa intenção e fazê-la valer como regra, foi criada a Lei que segue descrita a seguir.

\subsection{LEI № $12.527 / 2011$}

A Constituição Federal Brasileira garante o direito de acesso às informações de interesse coletivo ou geral, ou de interesse particular dos indivíduos ${ }^{13}$, conforme mostra o disposto:

"Todos têm direito a receber dos órgãos públicos informações de seu interesse particular, ou de interesse coletivo ou geral, que serão prestadas no prazo da lei, sob pena de responsabilidade, ressalvadas aquelas cujo sigilo seja imprescindível à segurança da sociedade e do Estado" (CONSITUIÇÃO FEDERAL, 1988, art. 5º, XXXIII).

Embora a Constituição Federal garanta o direito de acesso a informações públicas desde 1988, era necessário criar uma lei que regulamentasse esse direito, definindo procedimentos a serem observados tanto pela Administração Pública, quanto pela sociedade.

\footnotetext{
${ }^{13}$ Inciso XXXIII do art. 5o, no inciso II do § 3o do art. 37 e no § 20 do art. 216 da Constituição Federal.
} 
Para regulamentar esse direito, em 18 de novembro de 2011 foi sancionada a Lei $\mathrm{n}^{\mathrm{o}}$ 12.527/2011, a chamada Lei de Acesso à Informação, ou LAI.

Com a Lei de Acesso à Informação, a regra geral é a de que as informações produzidas pela Administração Pública sejam acessadas por qualquer pessoa. O acesso às informações públicas é importante para o aperfeiçoamento da gestão pública, para o respeito aos direitos e garantias individuais e para a melhoria da vida em sociedade. A LAI é composta por dispositivos gerais, aplicáveis a todos os entes federativos, e outros específicos, aplicáveis apenas ao Poder Executivo Federal, para os quais houve regulamentação específica. A partir de 16 de maio de 2012, todos aqueles que estivessem submetidos à Lei de Acesso à Informação deveriam disponibilizar informações públicas para a sociedade com agilidade, de forma transparente, clara e em linguagem de fácil compreensão.

Segundo o Art. $5^{\circ}$ da LAI: "É dever do Estado garantir o direito de acesso à informação, que será franqueada, mediante procedimentos objetivos e ágeis, de forma transparente, clara e em linguagem de fácil compreensão."

Assim posto, para que o cidadão possa utilizar a informação a que tem acesso, é preciso que ela possa ser compreendida. Para isso, os órgãos e entidades públicas devem se esforçar continuamente para aprimorar sua comunicação com a sociedade e para divulgar as informações em uma linguagem acessível. $\mathrm{O}$ acesso eficiente às informações públicas tem um papel fundamental na democracia, pois ao utilizar as informações públicas de maneira eficiente, o cidadão amplia suas possibilidades de participar do debate público e da gestão do Estado. Dessa forma, confirma-se que as informações públicas são importantes para os cidadãos e que elas devem estar disponíveis e acessíveis.

Diante desse contexto, os infográficos começaram a popularizar os sites de governo, para facilitar o acesso às informações. A seguir estão descritas as premissas observadas nos estudos das diretrizes do governo.

\subsection{CONSIDERAÇÕES FINAIS DO CAPÍTULO}

Analisando o material publicado pelo governo referente ao acesso à informação, foram destacadas as seguintes premissas, a serem observadas na elaboração de infográficos:

- garantir o acesso facilitado às informações digitais do governo;

- padronizar as propriedades digitais do Poder Executivo federal;

- imprimir mais credibilidade às informações disponíveis; 
- conhecer, entender e trabalhar com as pessoas que representam os atuais e potenciais utilizadores do produto (cidadãos);

- saber o contexto da utilização, ou seja, de onde o cidadão acessa, em que ambiente e em que condições;

- garantir a acessibilidade das informações;

- considerar que o ponto de partida do desenvolvimento é o usuário; e

- garantir que as informações estejam dispostas de forma objetiva, transparente, clara e em linguagem de fácil compreensão.

De forma a conhecer os processos de elaboração desses infográficos e as atividades relacionadas, para fim de verificar, dentre outras especificidades, a adequação às premissas relatadas acima, foram elaborados estudos e entrevistas, descritos no capítulo seguinte. 


\section{PROCESSO DE ELABORAÇÃO DE INFOGRÁFICOS}

Este capítulo apresenta uma análise de processos de elaboração encontrados na literatura e um estudo baseado em entrevistas com doze profissionais que elaboram infográficos para órgãos governamentais, a fim de conhecer os processos de trabalho na prática e compará-los com processos teóricos.

\subsection{PROCESSOS DE ELABORAÇÃO}

A necessidade de conhecer as práticas projetuais dos infografistas deu-se pelo fato de que compreender metodologias de design é relevante, tanto para a gestão da atividade quanto para auxiliar no progresso e eficiência dos produtos (HOWARD ET AL., 2006). Percebe-se, hoje, uma grande variedade de processos disponíveis para designers, em livros e em artigos acadêmicos, muitos com ênfase em projetos de design gráfico e de design de produto (e.g. BONSIEPE, 1984; BAXTER, 1995; DESIGN COUNCIL, 2006).

Mesmo com tantos processos na literatura, a velocidade e o dinamismo atuais configuram um momento que destaca a necessidade de nova abordagem de projeto, processo e produção adequados ao contexto atual (VIEIRA, 2007). Ainda de acordo com o autor, é flagrante a importância de metodologias de design que suportem a complexidade e apoiem o desenvolvimento ágil, eficiente e efetivo de novos produtos.

Para Panizza (2004), ao se discutir métodos projetuais é necessário primeiramente definir conceitos. A autora traz as definições dos verbetes do Aurélio, pela relevância da referência popular, de método - um processo ou técnica de ensino ou modo de proceder, e a definição de metodologia - o tratado dos métodos (BUARQUE, 1994:95 apud PANIZZA, 2004). Ainda, Freitas et al. (2013) afirma que a metodologia projetual seria um conjunto de procedimentos para o desenvolvimento de um determinado produto, relacionando métodos, técnicas e ferramentas.

Métodos e processos criativos têm sido discutidos e investigados há tempos. De acordo com Bonsiepe (1984), a metodologia é apenas uma ajuda ao processo projetual, orientando com técnicas e métodos para determinadas etapas. Já para Baxter (1995), os 
designers do futuro precisariam estar profundamente comprometidos com métodos sistemáticos de design. Segundo Löbach (2000), todo processo de design é um processo criativo, e é também um processo de solução de problemas. Mais recentemente, o Design Council (2006) relata que parte essencial de um bom design é um processo com base em um ciclo iterativo de desenvolvimento e testes.

Diante da confirmação de que os processos são relevantes para a prática de artefatos eficientes, esta pesquisa debruçou-se sobre os processos utilizados por designers que elaboram infográficos para o governo federal.

Para conhecer processos de elaboração de infográficos disponíveis na literatura, este estudo observou inicialmente pesquisas descrevendo características, classificações e princípios de artefatos como infográficos, visualizações de dados ou diagramas (e.g. BOUNFORD, 2000; TUFTE, 2001; ENGELHARDT, 2002; RAJAMANICKAN, 2005, MEIRELLES, 2013). Porém, não sendo este o foco da pesquisa, considerou-se os estudos cujos temas eram métodos de elaboração utilizados por designers de informação, tratando de infográficos e/ou de visualizações de informação em geral. Não foram considerados estudos de infográficos interativos, pois estes envolvem também outras disciplinas como o design de interação, que não compreendem o escopo do estudo.

Foram considerados três processos de elaboração: de Sless (2008), de Carvalho e Aragão (2012) e de Kanno (2013), descritos a seguir, em ordem cronológica de criação. Esses processos foram selecionados pela possibilidade de serem utilizados em processos de elaboração de infográficos digitais.

\subsubsection{PROCESSO DE SLESS}

David Sless (2008) descreve um processo para o design da informação que conta com sete estágios. Ainda que o processo não tenha sido criado especificamente para infográficos, esse processo foi considerado por ser voltado para o design da informação, intimamente ligado aos infográficos, como visto no primeiro capítulo desta dissertação. Os estágios estão descritos na tabela a seguir, na ordem proposta pelo autor. 


\begin{tabular}{|c|c|c|}
\hline № & ESTÁGIO & DESCRIÇÃO \\
\hline 1 & $\begin{array}{l}\text { Escopo } \\
\text { Scoping }\end{array}$ & $\begin{array}{l}\text { Garantir que todos os fatores necessários para o design ou } \\
\text { redesign são conhecidos e que estão sendo levados em conta, na } \\
\text { medida do possível. }\end{array}$ \\
\hline 2 & $\begin{array}{l}\text { Referências } \\
\text { Benchmarking }\end{array}$ & $\begin{array}{l}\text { Descobrir como similares estão se desenvolvendo e definir } \\
\text { requisitos dos novos artefatos. }\end{array}$ \\
\hline 3 & $\begin{array}{l}\text { Design } \\
\text { Designing }\end{array}$ & $\begin{array}{l}\text { Utilizar gráficos, tipografia, cores, linguagem apropriada e } \\
\text { estrutura adequada pra que os requisitos mencionados no item } \\
\text { acima estejam de acordo. }\end{array}$ \\
\hline 4 & $\begin{array}{l}\text { Testar } \\
\text { Testing }\end{array}$ & $\begin{array}{l}\text { Quando necessário, efetuar testes com usuários para } \\
\text { diagnosticar possíveis erros. }\end{array}$ \\
\hline 5 & $\begin{array}{l}\text { Refinar } \\
\text { Refining }\end{array}$ & Efetuar alterações para eliminar os erros \\
\hline 6 & $\begin{array}{l}\text { Implementar } \\
\text { Implementing }\end{array}$ & $\begin{array}{l}\text { Supervisionar a produção para garantir que a qualidade é a } \\
\text { esperada. }\end{array}$ \\
\hline 7 & $\begin{array}{l}\text { Monitorar } \\
\text { Monitoring }\end{array}$ & $\begin{array}{l}\text { Levantar dados para conhecer a opinião dos consumidores a } \\
\text { respeito do artefato e verificar se o nível de aceitação é o } \\
\text { esperado. }\end{array}$ \\
\hline
\end{tabular}

Tabela 2: Estágios do processo de Sless (2008), adaptado e traduzido.

O processo tem um desenho cíclico e apresenta as etapas de pesquisa antes da fase de design, conforme pode-se observar na Figura 7. Ele conta com etapas iterativa de testes e refinamentos antes da publicação e uma etapa de monitoramento pós-publicação. 


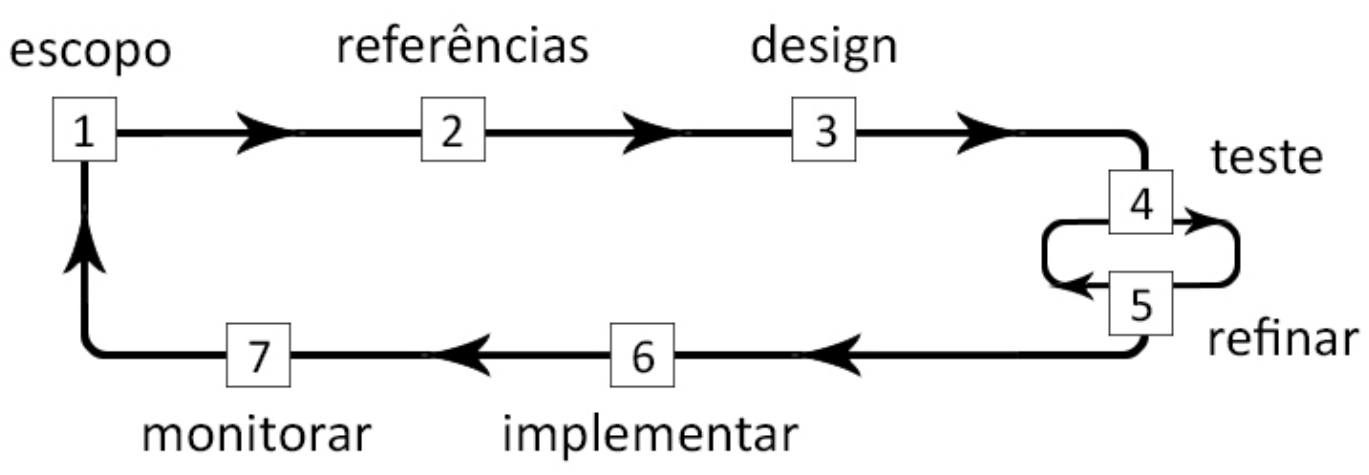

Figura 7: Processo de David Sless (2008) para o design da informação, adaptado e traduzido.

A importância da escolha do tipo adequado de linguagem gráfica, diagrama ou tipo de visualização de informação para a elaboração de um bom infográfico é mencionada no estágio 3 do processo.

\subsubsection{PROCESSO DE CARVALHO E ARAGÃO}

O segundo processo considerado para esta pesquisa foi proposto por Carvalho e Aragão (2012). O processo foi baseado em entrevistas com infografistas brasileiros da área jornalística. Como resultado, os autores propõem uma metodologia de produção de infográficos estáticos, que engloba três fases básicas (concepção, execução e acabamento), descritas a seguir.

- Fase de concepção

Compreende as etapas de definição e apropriação do tema. Visa compreender o assunto e identificar o que é importante sobre ele.

- Fase de execução

Compreende a elaboração do conteúdo e arquitetura da informação. Visa hierarquizar informações e compor elementos gráficos.

- Fase de acabamento

Compreende etapas de união de texto e projeto gráfico, ajustes, revisões e análise crítica. Visa juntar forma e conteúdo e cuidar dos detalhes de produção.

Em cada uma das fases constam etapas, no total de dez etapas, demonstradas na tabela a seguir. 


\begin{tabular}{|c|c|c|}
\hline \multicolumn{3}{|r|}{ FASE DE CONCEPÇÃO } \\
\hline № & ETAPA & DESCRIÇÃO \\
\hline 1 & Pauta & $\begin{array}{l}\text { Parte de uma sugestão de um tema a ser discutido e publicado. } \\
\text { Pode ser um tema de estudo, um fato ou uma notícia. Tal tema } \\
\text { deve ser relevante para determinada publicação e/ou público. }\end{array}$ \\
\hline 2 & $\begin{array}{l}\text { Apuração e } \\
\text { levantamento } \\
\text { de dados }\end{array}$ & $\begin{array}{l}\text { Definido o tema, parte-se para a pesquisa do conteúdo e como } \\
\text { este deve ser exposto. Leva-se em conta o propósito, os recursos } \\
\text { a serem utilizados, os usuários, dentre outras variáveis. }\end{array}$ \\
\hline \multicolumn{3}{|r|}{ FASE DE EXECUÇÃO } \\
\hline 3 & $\begin{array}{l}\text { Análise de } \\
\text { similares }\end{array}$ & Buscam-se referências e inspirações estéticas. \\
\hline 4 & $\begin{array}{l}\text { Elaboração de } \\
\text { conteúdo }\end{array}$ & $\begin{array}{l}\text { Após a avaliação daquilo que deve ser transmitido, elabora-se o } \\
\text { conteúdo informacional: a parte textual. }\end{array}$ \\
\hline 5 & $\begin{array}{l}\text { Arquitetura de } \\
\text { informação }\end{array}$ & $\begin{array}{l}\text { Processo de organizar as informações no espaço disponível. São } \\
\text { esboços contendo os elementos do leiaute (Título, imagem, } \\
\text { formas, dentre outros). É indicado realizar testes com leitores, a } \\
\text { fim de confirmar a legibilidade e leiturabilidade das informações. }\end{array}$ \\
\hline \multicolumn{3}{|r|}{ FASE DE ACABAMENTO } \\
\hline 6 & Arte-final & O esboço é convertido para peça finalizada. \\
\hline 7 & Acabamento & $\begin{array}{l}\text { Realização de ajustes da integração entre texto, imagens e/ou } \\
\text { formas. }\end{array}$ \\
\hline 8 & Revisão & $\begin{array}{l}\text { Revisão final do artefato. Se necessário, realizam-se novos } \\
\text { ajustes. }\end{array}$ \\
\hline 9 & Publicação & $\begin{array}{l}\text { Envia-se o infográfico para a produção, onde será publicado na } \\
\text { mídia: internet, jornal, revista, livro, etc. }\end{array}$ \\
\hline
\end{tabular}




\begin{tabular}{|l|l|l|}
\hline 10 & Análise crítica & $\begin{array}{l}\text { Após a publicação, é recomendada uma análise dos pontos } \\
\text { positivos e negativos do processo, no intuito de gerar } \\
\text { aprendizagem. }\end{array}$ \\
\hline
\end{tabular}

Tabela 3: Fases e etapas do processo de Carvalho e Aragão (2012), adaptado.

Esse processo tem um desenho linear e apresenta etapas de pesquisa tanto na fase de design quanto na fase de execução. Existe uma etapa de testes com usuários na etapa de arquitetura de informação, para verificação da leitura e legibilidade. Após a publicação, o único monitoramento mencionado é o referente ao próprio processo, e não um monitoramento do infográfico em si. As autoras ressaltam, ao final do estudo, o caráter sugestivo do processo, uma vez que ele pode e deve ser testado e editado de acordo com cada projeto.

Importante frisar que durante a explicação das etapas 2 e 5, as autoras mencionam a importância da observação de princípios de linguagem visual Horn (1999) e linguagem gráfica Twyman (1979) para a boa execução do infográfico.

\subsubsection{PROCESSO DE KANNO}

O terceiro processo desta pesquisa foi o de Kanno (2013), que propôs um processo de elaboração de infográficos com base em sua longa experiência na prática de elaboração de infográficos para periódicos. O processo conta com 7 etapas, sendo elas:

\begin{tabular}{|l|l|l|}
\hline No & ESTÁGIO & DESCRIÇÃo \\
\hline 1 & Planejamento & $\begin{array}{l}\text { Estabelecer um objetivo, reunir equipe para planejamento em } \\
\text { conjunto com cronograma. }\end{array}$ \\
\hline 2 & Investigação & Apurar informações e pesquisar em fontes confiáveis. \\
\hline 3 & A ideia gráfica & Rascunhos, ideias, brainstorming. \\
\hline 4 & O conteúdo & $\begin{array}{l}\text { Mantém o foco no objetivo do infográfico e no que o leitor } \\
\text { precisa saber. Pede opinião de terceiros sobre o conteúdo. }\end{array}$ \\
\hline 5 & O info na página & A prioridade é o conteúdo visual. Hierarquia dos elementos. \\
\hline
\end{tabular}




\begin{tabular}{|l|l|l|}
\hline 6 & Edição e revisão & Agrupar informações, título e subtítulos. Enviar para revisão. \\
\hline 7 & Feedback & Conversa com os envolvidos no processo. \\
\hline
\end{tabular}

Tabela 4: Processo de Kanno (2013), adaptado.

Esse processo tem um desenho linear e é o único que apresenta uma etapa de planejamento antes da etapa de pesquisa. Após a publicação, o único monitoramento mencionado é o referente ao próprio processo, e não um monitoramento do infográfico em si.

A importância da escolha do tipo adequado de linguagem gráfica, diagrama ou tipo de visualização de informação para a elaboração de um bom infográfico é mencionado em todo o livro, e acontece na etapa 5.

\subsubsection{ANÁLISE DOS PROCESSOS}

Os processos expostos aqui representam a visão teórica, mesmo tendo sido elaborados com observação da prática. Busca-se comparar caminhos teóricos disponíveis para confrontá-los com as práticas levantadas na entrevista com infografistas, verificando semelhanças e diferenças. O objetivo é propor melhorias na elaboração de infográficos para o governo. Dessa forma, um quadro comparativo foi construído, para uma melhor observação de fases e etapas constituintes.

Para a análise dos processos estudados e a comparação entre eles, optou-se por elaborar uma tabela contendo as atividades de cada um deles. Conforme a observação das atividades estudadas, foi percebido que os processos poderiam, para efeito comparativo, também ser divididos em três fases, como no processo de Carvalho e Aragão (2012), entretanto com uma separação diferente das etapas. No processo de Carvalho e Aragão, considera-se uma fase de concepção (i.e. o levantamento inicial de apuração), uma fase de execução (i.e. quando a definição de formas e conteúdo se apresenta) e uma fase de acabamento (i.e. engloba a etapa de finalização e discorre até o pós-publicação). Na tabela proposta, as atividades da primeira fase são semelhantes às do processo analisado, porém, a diferença maior é que a segunda fase termina na atividade de publicação e a terceira inicia-se após a publicação. As seguintes fases e etapas são propostas para a análise dos processos: 


\section{- Fase de apuração}

Etapas de pesquisas englobando planejamentos, pesquisas de mercado e de referências, objetivos, temas relacionados, levantamento de taxonomias e estilos gráficos, dentre outros.

- Fase de execução

Do início dos esboços até a publicação. Compreende elaboração de textos, arquitetura de informação, definição da linguagem gráfica, tipos de gráficos, diagramas ou outros tipos de visualização de informação, leiautes, esboços e a publicação do infográfico.

\section{- Fase de pós-publicação}

Etapas que acontecem após o infográfico ser publicado. Compreende análise do processo em si e do artefato elaborado.

Demonstra-se a seguir uma tabela dividida nas três fases descritas acima. As primeiras colunas representam as atividades dos processos estudados, numeradas. Quando as atividades dos três processos são colocadas em lista, são contabilizados 14 grupos de atividades. Considera-se grupos de atividades, pois algumas delas, como "Revisar informações e fazer ajustes", compreendem duas atividades na mesma descrição (a atividade de revisar e a de efetuar ajustes).

Nas colunas seguintes são identificados os autores dos processos. Nas linhas são apresentadas com um $\mathrm{X}$ as atividades verificadas em cada processo. Se a atividade não consta do processo relacionado, a célula da tabela permanece vazia.

\begin{tabular}{|c|c|c|c|c|}
\hline \multicolumn{5}{|c|}{ FASE DE APURAÇÃO } \\
\hline № & ATIVIDADE & SLESS & CARVALHO E ARAGÃO & KANNO \\
\hline 1 & $\begin{array}{l}\text { Identificar as } \\
\text { necessidades e } \\
\text { objetivos }\end{array}$ & $X$ & $\mathrm{X}$ & $X$ \\
\hline 2 & $\begin{array}{l}\text { Planejar prazos e } \\
\text { atividades }\end{array}$ & & & $X$ \\
\hline 3 & $\begin{array}{l}\text { Pesquisar sobre o } \\
\text { tema }\end{array}$ & & $x$ & $x$ \\
\hline 4 & Analisar similares & $x$ & $x$ & \\
\hline
\end{tabular}




\begin{tabular}{|c|c|c|c|c|}
\hline \multicolumn{5}{|c|}{ FASE DE EXECUÇÃO } \\
\hline 5 & $\begin{array}{l}\text { Elaborar } \\
\text { conteúdo textual }\end{array}$ & & $x$ & \\
\hline 6 & $\begin{array}{l}\text { Idear e elaborar } \\
\text { rascunhos }\end{array}$ & & $x$ & $x$ \\
\hline 7 & $\begin{array}{l}\text { Testar com } \\
\text { usuários }\end{array}$ & & $x$ & $x$ \\
\hline 8 & $\begin{array}{l}\text { Elaborar } \\
\text { conteúdo textual }\end{array}$ & & $x$ & $x$ \\
\hline 9 & Elaborar o design & $x$ & $x$ & $x$ \\
\hline 10 & $\begin{array}{l}\text { Testar com } \\
\text { usuários }\end{array}$ & $X$ & $x$ & \\
\hline 11 & $\begin{array}{l}\text { Revisar } \\
\text { informações e } \\
\text { fazer ajustes }\end{array}$ & $x$ & $x$ & $x$ \\
\hline 12 & Publicar & $x$ & $x$ & \\
\hline \multicolumn{5}{|c|}{ FASE DE PÓS-PUBLICAÇÃO } \\
\hline 13 & $\begin{array}{l}\text { Analisar o } \\
\text { processo }\end{array}$ & & $x$ & $x$ \\
\hline 14 & $\begin{array}{l}\text { Testar com } \\
\text { usuários }\end{array}$ & $x$ & & \\
\hline
\end{tabular}

Tabela 5: Comparação de processos com fases e atividades.

Observa-se na tabela comparativa que algumas mesmas atividades aparecem em ordem diferente, como a atividade "Elaborar conteúdo textual", que é apresentada na fase de execução, linha 5, no processo de Carvalho e Aragão (2012) e na linha 8 no processo de Kanno (2013).

A atividade "Testar com usuários" aparece em três momentos diferentes: na fase de execução (linha 7) no processo de Carvalho e Aragão (2012) e Kanno (2013), para verificação da leitura dos textos na etapa de arquitetura de informação. Ainda na mesma fase (linha 10), os testes com usuários aparecem nos processos de Sless (2008) e de Carvalho e Aragão (2012), para verificação do artefato pronto, antes de ser publicado, e na fase de pós- 
publicação (linha 13) no processo de Sless (2008), para verificação da opinião e aceitação do usuário.

Ao observar as atividades de cada processo e ordem em que são apresentadas, obtemos uma lista com duas atividades que se repetem: "Testar com usuários" e "Elaborar conteúdo textual”.

Quanto ao momento correto para a atividade de "Testar com usuários", Gaffney (1999) afirma que o ideal é que os testes sejam aplicados antes da publicação, para que questões significantes sejam identificadas e corrigidas. O autor menciona que os testes podem ser aplicados em diversos estágios do processo de design, mas que eles seriam mais apropriados nas etapas iniciais. Em concordância com o autor, mas a respeito dos aspectos da infografia jornalística, Dur (2012) alega que os dados do artefato devem ser analisados corretamente e que a solução de design deve ser relevante e compreensível, caso contrário, não haverá sentido em apresentar ao leitor uma massa de dados composta de números complicados em forma de gráficos. Isto posto, as atividades permanecerão repetidas na lista de atividades.

A atividade "Elaborar conteúdo textual" também aparece repetida, já que dois processos efetuam a atividade em diferentes momentos. Optou-se por posicionar a fase de elaboração de texto antes do primeiro teste com usuário, para que essa fase já conte com o texto elaborado. Dessa forma, tem-se a lista abaixo como a compilação final dos processos para este estudo, contendo 13 atividades ou grupos de atividades, divididas em fases.

\begin{tabular}{|l|l|}
\hline \multicolumn{2}{|c|}{ FASE DE APURAÇÃO } \\
\hline 1 & Identificar as necessidades e objetivos \\
\hline 2 & Planejar prazos e atividades \\
\hline 3 & Pesquisar sobre o tema \\
\hline 4 & Analisar similares \\
\hline & \\
\hline 5 & Elaborar conteúdo textual \\
\hline 6 & Idear e elaborar rascunhos \\
\hline
\end{tabular}




\begin{tabular}{|l|l|}
\hline 7 & Testar com usuários \\
\hline 8 & Elaborar o design \\
\hline 9 & Testar com usuários \\
\hline 10 & Revisar informações e fazer ajustes \\
\hline 11 & Publicar \\
\hline \multicolumn{2}{|l}{} \\
\hline 12 & Analisar o processo \\
\hline 13 & Testar com usuários \\
\hline
\end{tabular}

Tabela 6: Fases e atividades propostas para efeito comparativo.

Esta lista de fases e atividades servirá para efeitos de comparação com os processos de elaboração adotados pelos infografistas do governo. Por conseguinte, a próxima seção descreverá a pesquisa com os infografistas.

\subsection{A PESQUISA COM INFOGRAFISTAS}

Nesta seção, parte-se da afirmação de Meirelles (2013:9) de que "o entendimento completo de como alguns resolveram problemas de design pode permitir que outros possam desenvolver com sucesso uma série de habilidades para caminhos assertivos e produtivos." Dessa forma, é reforçada a ideia de que conhecer as práticas de uns profisssionais pode contribuir para as práticas de outros. O objetivo do estudo descrito nesta seção era o de conhecer como trabalhavam os infografistas no governo.

Para conhecer os processos de elaboração dos infografistas do governo foi elaborada uma entrevista, com perguntas sobre as práticas que estes aplicavam em seus trabalhos. As perguntas foram compostas com base nos processos estudados e na lista de atividades e fases consideradas como as melhores práticas. Doze entrevistas foram consideradas neste estudo, conforme descrição a seguir.

\subsubsection{MÉTODO E PARTICIPANTES}


Para a definição do método da pesquisa, foi escolhido o formato de entrevista, utilizada devido à natureza qualitativa, uma vez que o objetivo era ampliar a compreensão sobre as experiências dos participantes. As vantagens deste método foram discutidas por Mack et al. (2005). Segundo os autores, uma das vantagens dos métodos qualitativos na pesquisa exploratória é o uso de perguntas abertas, que dá aos participantes a oportunidade de responder em suas próprias palavras, em vez de forçá-los a escolher a partir de respostas fixas, como os métodos quantitativos (MACK ET AL., 2005).

Buscou-se na entrevista coletar amostras que indicassem a prática projetual de infografistas no governo brasileiro, com o intuito de conhecer os processos de elaboração dos profissionais, assim como suas opiniões quanto a vantagens e desvantagens, restrições e limitações que encontram no dia-a-dia profissional.

Para tanto, uma lista de perguntas foi composta com base nos processos estudados e na lista de atividades e fases consideradas como as melhores práticas. Além disso, para a elaboração das perguntas da entrevista, foram consideradas as premissas observadas no estudo sobre o direcionamento do governo sobre o acesso à informação.

Para conhecer o processo dos participantes, foi utilizado como instrumento de coleta de dados um roteiro para entrevista semiestruturado, contendo perguntas que abrangiam as atividades colocadas em prática em cada fase, a opinião sobre os processos praticados e os fatores que pudessem interferir na elaboração dos infográficos. As entrevistas semiestruturadas combinam perguntas abertas e fechadas, nas quais o informante tem a possibilidade de discorrer sobre o tema proposto (BONI, 2005). O roteiro de perguntas da entrevista consta do apêndice A desta pesquisa.

Para a definição dos participantes da pesquisa, foi estabelecido como recorte que apenas infografistas que elaboram infográficos para o governo federal seriam considerados. Assim sendo, a procura pelos profissionais foi iniciada pelos infográficos encontrados nos sites do governo federal, na tentativa de rastrear onde se encontravam os profissionais que os elaboraram. Os nomes dos infografistas na maioria das vezes não são publicados, portanto, para encontrá-los, foi necessário um empenho em estabelecer contato com as assessorias de comunicação dos órgãos, que usualmente são os responsáveis pelos conteúdos nos respectivos sites.

Foram contatados quinze infografistas de sete órgãos do governo. Destes, doze infografistas de quatro órgãos do governo aceitaram participar da pesquisa. Foram realizadas doze entrevistas, de quatro órgãos do governo, sendo oito entrevistas presenciais e quatro via telefone. As entrevistas foram marcadas previamente e aconteceram no ambiente de trabalho 
dos infografistas ou em local público. As entrevistas presenciais foram gravadas, com a permissão dos entrevistados, já as entrevistas por telefone não foram gravadas.

Considerou-se desnecessário o recrutamento de novos participantes, uma vez que a semelhança das respostas obtidas sugeria ser improvável obter novos subsídios teóricos ou empíricos com a continuação das entrevistas.

A seguir estão relatados os resultados das entrevistas com os infografistas.

\subsection{RESULTADOS DAS ENTREVISTAS}

Os resultados despontados na análise estão descritos nesta seção, divididos por informações a respeito do perfil do infografista e do ambiente de trabalho, seguidas das fases de processo propostas neste estudo: fase de apuração, fase de execução e fase de póspublicação.

\subsubsection{PERFIL E AMBIENTE DE TRABALHO}

Ao buscar pessoas que haviam elaborado infográficos para o governo brasileiro na esfera federal, a primeira verificação foi a de que esses profissionais estão alocados, em sua maioria, em Brasília. Foram entrevistados doze infografistas que elaboram ou elaboraram infográficos para o governo brasileiro. Onze profissionais estavam em Brasília, próximos às equipes com quem trabalhavam, e apenas um em São Paulo, trabalhando remotamente. A proximidade do profissional com a equipe pode ser considerada uma vantagem em termos criativos, já que a comunicação entre os integrantes pode ser facilitada e, havendo fluência no trabalho em equipe, há possibilidades para vários pontos de vista criativos (LANA, 2011; MOGGRIDGE, 2008).

Dos entrevistados, nove eram do gênero masculino e três do gênero feminino, expondo na amostra uma dominância do gênero masculino na elaboração de infográficos.

A média de idade dos entrevistados era de 27 anos, com respostas variando de 21 a 37 anos de idade.

Quanto à formação acadêmica, encontramos a maioria de publicitários, alguns designers e outras respostas, como mostra a Tabela 7 : 


\begin{tabular}{|c|c|}
\hline FORMAÇÃO & $\begin{array}{c}\text { QUANTIDADE DE } \\
\text { ENTREVISTADOS }\end{array}$ \\
\hline Publicitário & 6 \\
\hline Designer & 3 \\
\hline Jornalista & 1 \\
\hline Sem nível superior & 2 \\
\hline
\end{tabular}

Tabela 7: Formação acadêmica dos entrevistados.

Quanto ao vínculo profissional do entrevistado com o governo, encontramos servidores concursados do órgão, servidores cedidos, profissionais terceirizados, ocupantes de cargo em comissão e freelancers, conforme pode ser observado na Tabela 8. Verifica-se que há diversas formas de contratação desses profissionais e que a maioria não era servidor concursado. A crescente demanda por infográficos em sites de governo pode levar a uma necessidade do próprio governo de averiguar quais as melhores formas de contratação de profissionais adequados para a atividade de elaboração de infográficos.

\begin{tabular}{|c|c|}
\hline TIPO DE VÍNCULO & $\begin{array}{c}\text { QUANTIDADE DE } \\
\text { ENTREVISTADOS }\end{array}$ \\
\hline Servidor & 4 \\
\hline Comissionado não-servidor & 4 \\
\hline Freelancer & 2 \\
\hline Terceirizado & 2 \\
\hline
\end{tabular}

Tabela 8: Vínculo com o governo.

Os profissionais tinham em média cinco anos de profissão e faziam infográficos há pelo menos três anos, sendo tanto para o governo quanto para outras instituições. A maioria relatou ter elaborado dezenas de infográficos, e alguns relataram ter elaborado centenas deles. 
Metade dos entrevistados disse que elabora muitos infográficos para o governo e a outra metade relatou elaborar poucos infográficos para o governo. A quantidade varia de acordo com o órgão em que estão trabalhando.

A grande maioria dos infografistas do governo disse não conhecer outros infografistas de outros órgãos, para trocar experiências e conhecimento, como o observado na fala de um infografista entrevistado:

\section{"Não temos contato com outros infografistas do governo. Seria bom trocar algumas ideias e aprender com erros e acertos dos outros. "}

Perguntados sobre metodologia com a questão "Você segue alguma metodologia de trabalho para elaboração de infográficos? Qual?", nenhum dos entrevistados disse seguir uma metodologia específica para a elaboração dos infográficos.

Foi solicitado aos entrevistados que descrevessem as etapas do seu processo de trabalho de elaboração de infográficos, perguntando-os "Como é seu processo de elaboração de infográficos?" A maioria relatou que o processo de trabalho a ser seguido muitas vezes é alterado, para adequar-se a uma necessidade de prazo: assuntos complexos demandam mais tempo de execução, prazos curtos demandam etapas mais curtas no processo, ou mesmo subtração de etapas. Como se pode confirmar com a transcrição de uma frase de um discurso direto de um entrevistado:

\section{| "A forma de trabalho depende do prazo e da complexidade."}

A seguir estão as respostas dos entrevistados sobre as etapas e atividades, divididas em cada uma das três fases propostas neste estudo para efeitos comparativos: fase de apuração, fase de execução e fase de pós-publicação.

\subsubsection{FASE DE APURAÇÃO}

O fluxo de trabalho da maioria dos entrevistados é iniciado com uma solicitação dos superiores diretos, de elaborar um infográfico que pode complementar uma matéria jornalística, uma divulgação ou uma campanha de um programa. Esses infográficos são produzidos para serem publicados no site do órgão e em redes sociais oficiais do governo e, algumas vezes, em materiais impressos. 
Ocasionalmente a sugestão da elaboração do infográfico parte do próprio infografista, propondo um infográfico para esclarecimentos de um assunto que esteja em voga na mídia.

A solicitação chega de formas diferentes, dependendo do órgão. Essa solicitação foi chamada de briefing pela maior parte dos infografistas. Briefing é o documento contendo todas as informações relevantes aos interessados no projeto (PHILLIPS, 2008). O briefing contém o objetivo que se precisa alcançar com o infográfico, seja ele complementar uma matéria ou texto, ou individual, que passa sozinho uma informação aos cidadãos. Alguns infografistas relataram ter elaborado um documento de briefing padrão, a ser respondido pelos solicitantes, com informações relevantes e padronizadas para todos os infográficos.

Faz parte do briefing a informação de qual o público-alvo do infográfico. Há casos em que o público-alvo é específico (e.g. pais de adolescentes, pessoas que moram em áreas mais suscetíveis a certas doenças, mulheres que estejam amamentando), porém, há ocasiões em que não há público-alvo determinado (e.g. resultados e estatísticas de programas, campanhas de conscientização ambiental, dados econômicos). $\mathrm{Na}$ maioria das vezes o público-alvo dos infográficos é composto também por jornalistas, pois estes se utilizam dos infográficos como insumo para elaborarem suas próprias matérias para mídias especializadas. Infográficos de alguns órgãos são elaborados para apresentações de ministros e secretários em coletivas de imprensa e eventos. Nesses casos, o público-alvo também é composto de técnicos e especialistas no assunto, mesmo que, após a apresentação, o infográfico seja publicado nos sites oficiais do órgão, para acesso ao público em geral. A diversidade de público dos infográficos do governo mostra-se uma notável característica.

Muitas vezes o release jornalístico ou pauta jornalística é o que o infografista recebe para iniciar seu trabalho. Esses documentos são gerados por jornalistas, redatores e editores da área de assessoria de comunicação dos órgãos. Em tais situações, muitos relataram que solicitam, além da pauta/release, a matéria completa para conhecer mais sobre o assunto. Outras vezes o que chega para o infografista é um documento puro, com dados brutos, a ser analisado. Esse documento pode ser uma lei, portaria, outro ato normativo qualquer, uma planilha numérica etc. Nesses casos, o infografista precisa se inteirar do assunto, de forma a saber quais as informações mais relevantes para compor o infográfico. Muitos relataram que ao passo em que vão lidando com o mesmo assunto, vão aprendendo seus pormenores, e, cada vez que precisam tratar de um assunto relacionado, vai ficando mais fácil elaborá-lo. Porém, cada vez que surge um assunto novo, uma nova curva de aprendizado se faz necessária, como ilustrado com o argumento de um dos entrevistados: 
"Áreas técnicas muitas vezes tem assuntos difíceis de entender, com
terminologia complicada. É preciso entender do que se está tratando, e muitas
vezes não há tempo. Quando se fica mais tempo em uma área, vamos
entendendo aos poucos os termos e funcionamentos, ai facilita."

Ao receber o material, o infografista inicia sua análise e compreensão do material, de forma a compreender o assunto e aprendê-lo, de modo a ter conhecimento suficiente para proporcionar embasamento ao seu processo criativo.

\subsubsection{FASE DE EXECUÇÃO}

Com a análise concluída, eles partem para a seleção do conteúdo textual e numérico que fará parte do infográfico. Alguns relataram que contam com a participação de uma pessoa da área técnica para essa atividade. Isso se dá pela responsabilidade com a autenticidade e fidedignidade do conteúdo, que não pode correr o risco de estar errado, como veremos em algumas falas transcritas das entrevistas:

"Informações técnicas e com dados numéricos exigem uma responsabilidade
muito grande, pois o meio a ser publicado é o oficial do governo. Dessa forma,
há um cuidado grande em deixar a área técnica somente preparar os textos e
conteúdos."
"Qualquer informação errada publicada gera uma grande repercussão. Os
usuários notam logo e entram em contato. Nada pode sair errado."

Além das informações estarem corretas, a grande maioria expôs a importância do conteúdo textual para um bom infográfico. Segundo eles, o texto precisa ser conciso e bem escrito, para cumprir seus objetivos. Dessa forma, muitas vezes o designer ajusta o texto da área técnica para melhorar a compreensão da informação sem mudar a interpretação:

\footnotetext{
"O ideal é ter alguém que saiba elaborar textos para infografia. Geralmente cabe ao infografista a tarefa de propor os textos. Muitas pessoas não sabem escrever para a infografia, e o designer acaba ajustando esses textos".
} 
Após a definição do conteúdo que constituirá o infográfico, os infografistas passam à fase de busca de referências visuais, buscando em sites da web elementos referentes aos assuntos relacionados e tendências de elementos visuais em infográficos.

Com conhecimento do assunto e a busca de similares e referências, o profissional inicia seu processo criativo de elaboração de leiaute, que pode englobar cores, texturas, fontes, ilustrações e ícones. Um número pequeno de entrevistados mencionou produzir rascunhos iniciais, a maioria alegou partir diretamente para a criação da apresentação visual. Alguns profissionais mencionaram ter um padrão visual a ser seguido, criado interna e especificamente para os infográficos do órgão. Nesses casos, eles guardam uma biblioteca virtual com ícones mais usados, paleta de cores e estilos fontes para reaproveitamento. Outros criam livremente de acordo com o tema proposto. Muitos dos entrevistados contaram que há um limite para a criatividade dos infográficos governamentais: por se tratar de informação oficial, há um limite para o uso de humor, informalidade ou inovações, salvo em alguns casos elaborados para publicação em redes de mídias sociais, de assuntos menos austeros. Como mencionou um entrevistado:

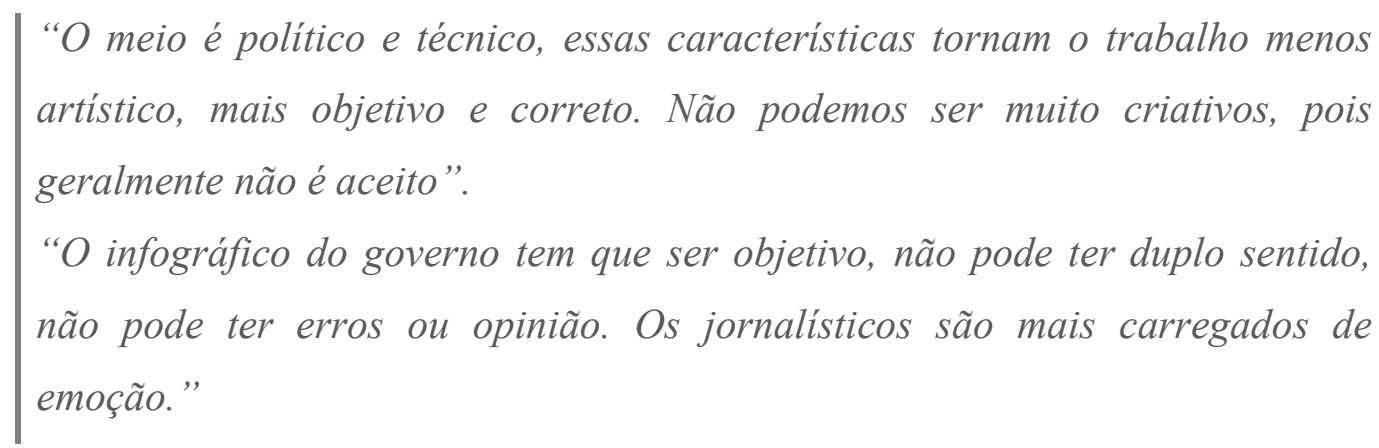

Nos casos em que o infográfico é interativo, a fase de criação é elaborada em conjunto com o programador que faz a animação do infográfico. Nos casos de infográficos não interativos, o infografista efetua um trabalho criativo individual:

\section{| "Em projetos impressos ou digitais estáticos, geralmente se trabalha sozinho. Eles são mais fáceis do que os digitais interativos".}

Infográficos interativos ou animados em motion design requerem uma fase específica de programação, logo após a definição de leiaute. A programação é geralmente executada por um desenvolvedor ou designer com conhecimentos de ferramentas de animação gráfica. 
Poucos infografistas relataram elaborar diversas propostas de leiaute, geralmente é apresentada apenas uma proposta para a fase de avaliação. Nessa fase a área técnica e os superiores que solicitaram o infográfico verificam se ele está correto e de acordo com as expectativas dos solicitantes. Textos, imagens, cores e estilos, tudo precisa estar de acordo com o posicionamento do órgão. A fase de avaliação é muito importante devido a responsabilidade das informações publicadas, como foi verificado na fase de seleção das informações do infográfico. Caso um infográfico não seja aprovado, ele pode voltar para a fase de elaboração de leiaute ou mesmo de elaboração de texto. Ainda sobre essa importância, agora na fase de homologação, seguem algumas falas que confirmam a afirmativa:

$$
\begin{aligned}
& \text { "É importante a área técnica avaliar o infográfico, pois muitas vezes usamos } \\
& \text { termos indevidos, que a área técnica identificou que poderia ter um sentido } \\
& \text { diferente do esperado. Isso já aconteceu também com ícones, a área técnica } \\
& \text { tem uma visão da simbologia que certas imagens podem ter e nos alertam } \\
& \text { quanto ao uso inadequado." } \\
& \text { "Há uma responsabilidade técnica muito grande, não podemos errar um } \\
& \text { número sequer. Já houve casos de erro que a imprensa logo publicou e aquilo } \\
& \text { tomou uma proporção absurda." }
\end{aligned}
$$

Alguns relatos de infográficos reprovados pelos avaliadores trazem variáveis diversas nos critérios de verificação, como questões políticas e religiosas. A frase de um dos infografistas abaixo explica essas variáveis:

"Houve vezes em que questões políticas e religiosas impactaram o desenho do
infográfico. Mas essas restrições acontecem também em empresas privadas,
não são exclusivas do governo".

\subsubsection{FASE DE PÓS-PUBLICAÇÃO}

Questionados sobre as vantagens de um infográfico de informação pública governamental, os infografistas responderam de diversas formas diferentes. Na Figura 8, uma nuvem de palavras gerada a partir das respostas, podem-se perceber os termos mais mencionados nas respostas: 


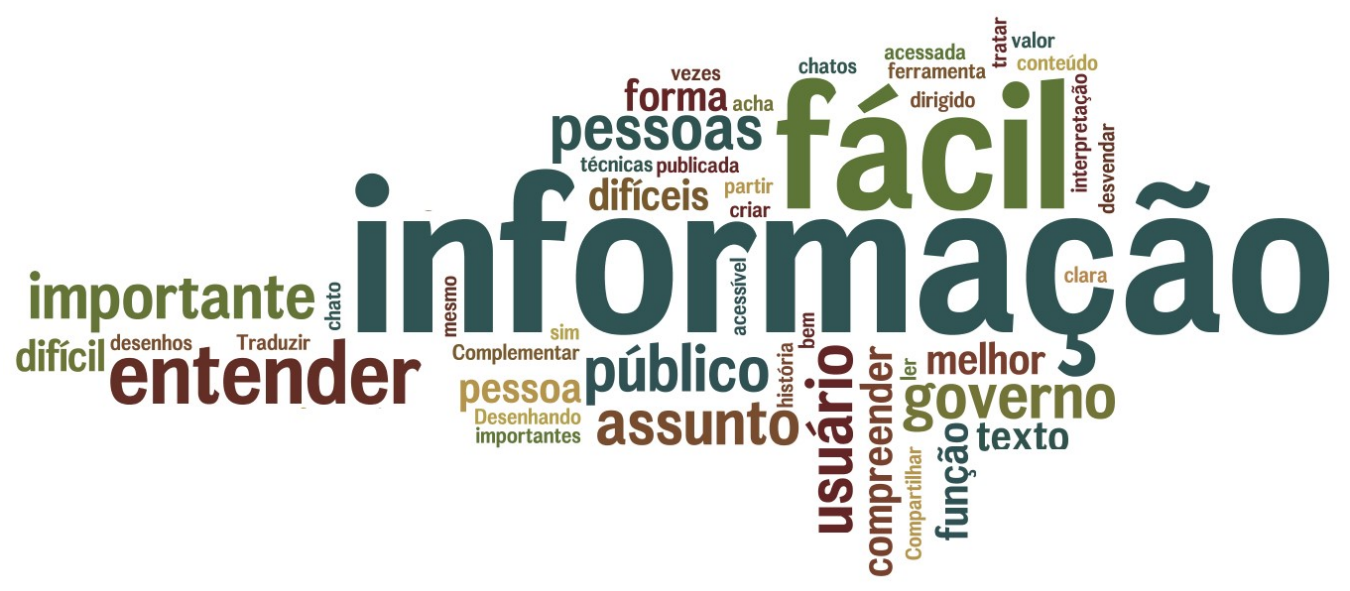

Figura 8: Nuvem de palavras com as vantagens de um infográfico do governo, gerada pelo Wordle ${ }^{14}$.

A maioria das respostas mencionava que o conteúdo de sites governamentais é de difícil entendimento e geralmente desinteressante:

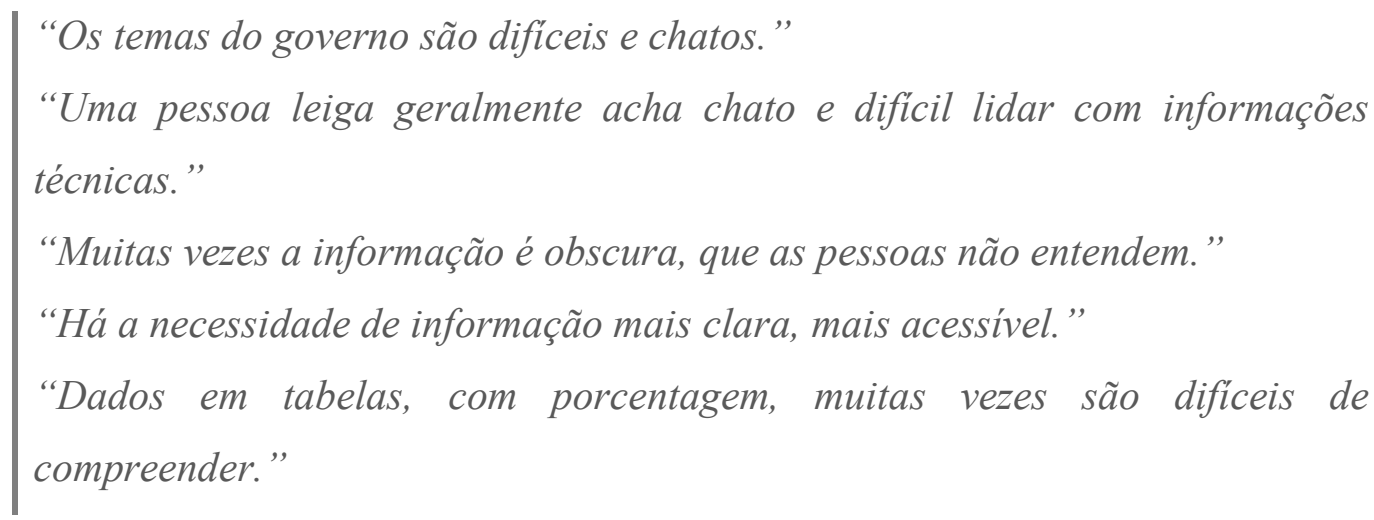

Sendo os termos muitas vezes difíceis e assuntos complexos, muitos mencionaram que a função do infográfico é tornar essa informação dita difícil e desinteressante em informação de fácil compreensão para os usuários. Vários trechos das entrevistas explicam esta temática, como os exemplos a seguir:

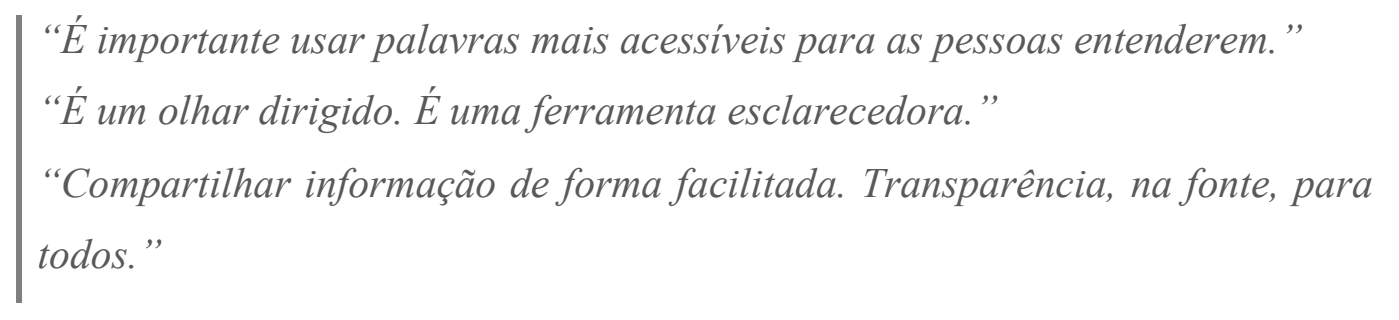

\footnotetext{
${ }^{14}$ Ferramenta online de geração de nuvem de palavras, disponível em http://www.wordle.net.
} 


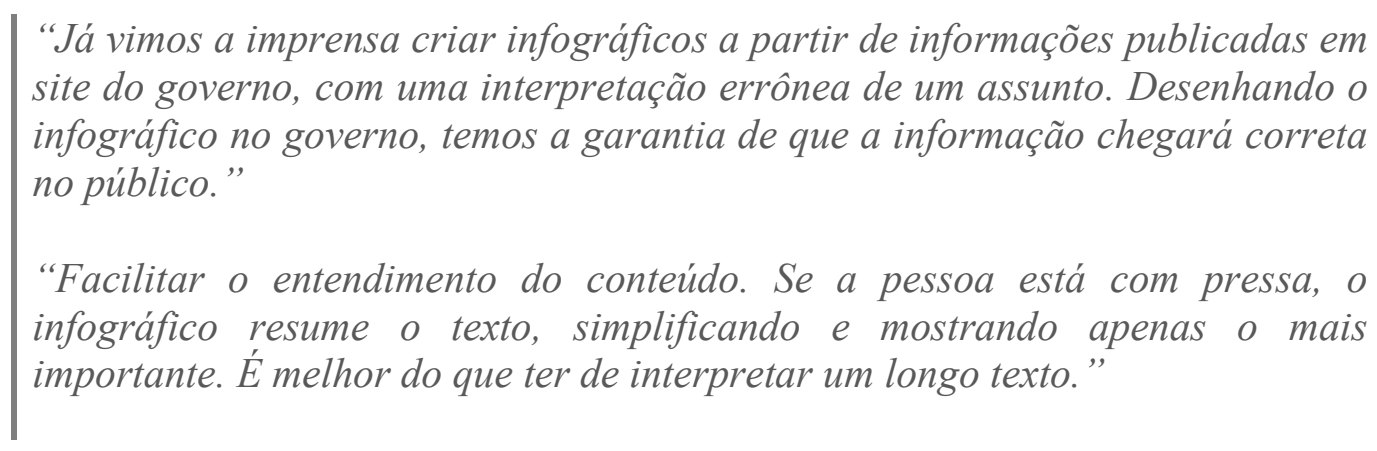

Perguntou-se: "Seria bom ter feedbacks de usuários?" Todos os entrevistados mencionaram que seria vantajoso ter feedback de usuários, uma vez que isso seria material relevante a ser considerado nos infográficos futuros. Ainda que não haja opinião dos cidadãos, os infografistas mencionaram ter bons feedbacks e elogios de gestores do órgão onde trabalham, de outros órgãos e de jornalistas:

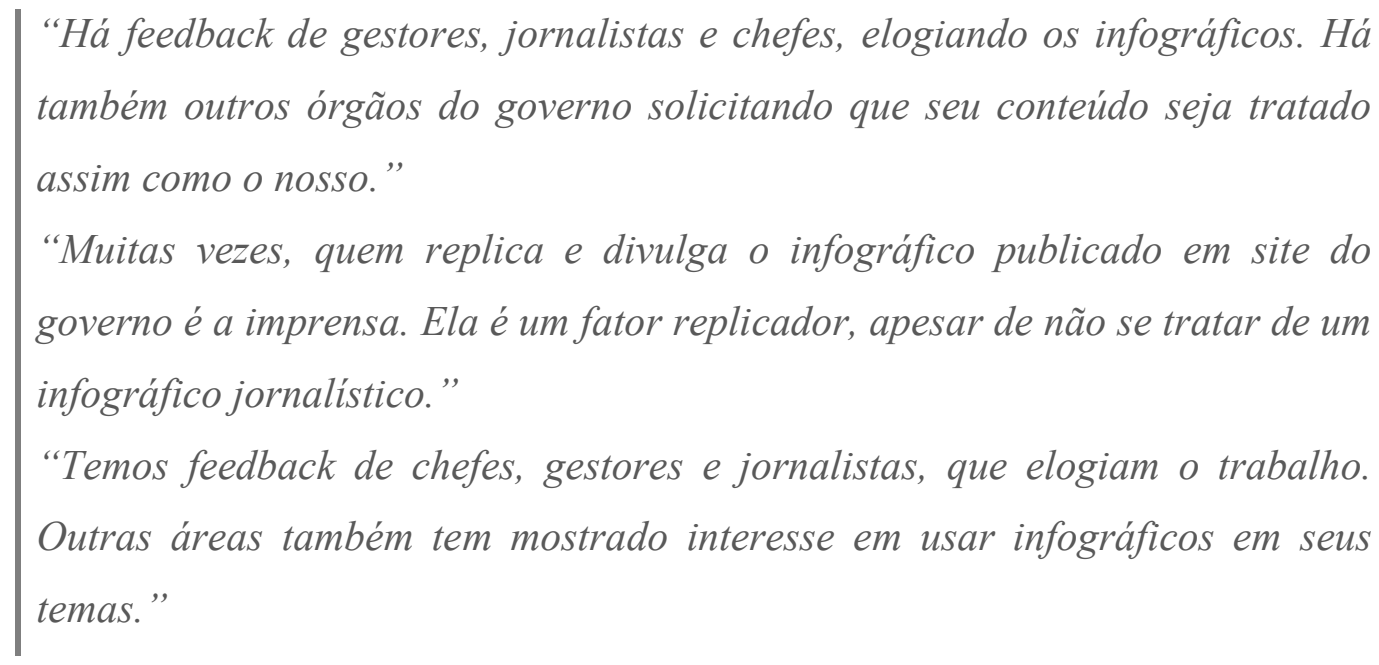

Depois da publicação, poucos profissionais informaram que costumam acompanhar métricas de acesso das páginas onde estão publicados os infográfícos. As medidas tomadas geralmente são o tempo despendido na página e a quantidade de acessos. Quando os infográficos são publicados em redes de mídias sociais, são acompanhadas também as informações de "Curtir", compartilhamentos e comentários. Quanto mais cliques, acessos, compartilhamentos, "Curtir" e tempo de permanência na página, melhor o desempenho do infográfico para os infografistas:

\footnotetext{
"Sabemos das métricas de acesso à imagem, apenas. E se as pessoas compartilharam a imagem ou o link".
} 


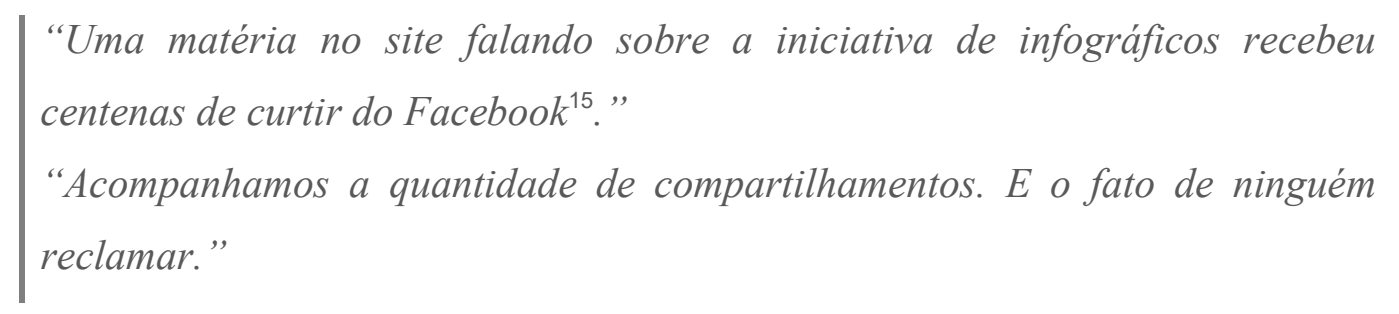

Um entrevistado relatou que quando uma matéria é acompanhada de um infográfico no site do órgão em que trabalha, a página apresenta mais tempo de permanência do usuário, o que significaria que o usuário se interessou mais na matéria. Geralmente ele percebe um aumento de $40 \%$ no tempo médio de matérias sem infográficos.

Os relatos de acompanhamento de métricas aconteceram nos casos em que os infografistas trabalhavam no órgão em questão. Nos casos de freelancers, eles pouco sabiam dos infográficos após a publicação:

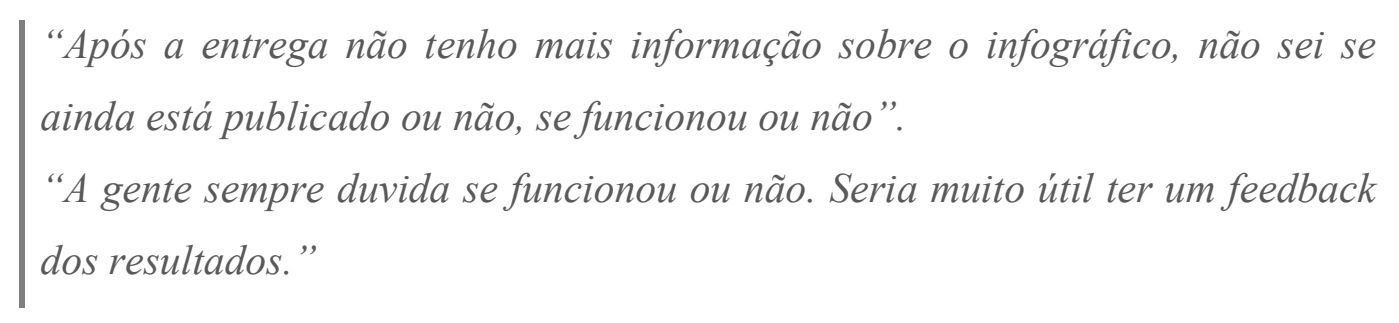

Percebe-se que testes com usuários dotariam os infografistas de informações relevantes que poderiam contribuir na elaboração de infográficos.

A respeito das restrições que os profissionais encontram ao elaborar infográficos para o governo, foi feita a pergunta: “Quais os impedimentos para a elaboração de infográficos interativos para o governo, em sua opinião?" Foram encontrados como resposta os tópicos descritos a seguir.

Prazo - Quase todos relataram que o prazo de elaboração é sempre muito curto, tornando-se um impeditivo na criatividade e no refinamento da arte final:

\footnotetext{
| "Muitos dados numéricos estatísticos são pereciveis, eles servem para hoje, mas podem estar desatualizados amanhã. Isso faz com que, muitas vezes, precisemos correr para entregar os infográficos em um prazo curto."
}

\footnotetext{
${ }^{15}$ Rede de mídia social de grande acesso.
} 
Imagens, Ícones e Ilustrações - Muitos expuseram dificuldade em ter acesso a bancos de ícones e imagens. Como o prazo geralmente é curto, não há tempo hábil para a criação de ilustrações ou ícones. A equipe conta apenas com bancos de imagens gratuitos e de direitos de uso cedidos.

Mudança de equipe - Alguns mencionaram que o fato dos membros das equipes serem alterados a cada novo mandato de governo é impactante na elaboração dos infográfícos, uma vez que é necessário conhecer os gostos e opiniões dos novos solicitantes/avaliadores:

\section{"Quando muda a equipe, mudam os gostos. Precisamos sempre nos adequar aos gostos dos que aprovam os infográficos, como a preferência por cores, imagens etc."}

Já a respeito de infográficos interativos, cada vez mais presentes em mídias jornalísticas, porém ainda não tão comuns em sites do governo, os entrevistados mencionaram as restrições que encontram na elaboração de infográficos interativos:

- falta de ferramentas específicas para construção de animações;

- falta de profissionais com conhecimento de animação/interatividade;

- limitações nos sistemas de gerenciamento de conteúdo utilizados;

- questões de acessibilidade que impedem extensões e componentes não acessíveis; e

- prazo para desenvolvimento.

A despeito da questão de acessibilidade mencionada nos infográficos interativos, essas premissas nem sempre são consideradas na elaboração de infográficos estáticos. A maioria relatou não seguir especificação a respeito de acessibilidade. Como a acessibilidade dos infográficos estáticos (geralmente arquivos de imagem com extensão PNG ou JPG ${ }^{16}$ ) se daria na descrição textual da imagem, essa tarefa seria do publicador do infográfico na web, e não de quem o elabora.

Foi perguntado: "Geralmente há um objetivo a ser alcançado com o infográfico a ser elaborado?" e "Você acha que os infográficos de informação pública (governamental) cumprem seus objetivos?" Todos os entrevistados declararam que todo infográfico que elaboram tem, sim, um objetivo específico e a grande maioria acredita que

\footnotetext{
${ }^{16}$ Extensões de imagens em bitmap estáticas.
} 
eles cumprem seus objetivos. Alguns infografistas relataram acreditar que nem todo infográfico cumpre seu papel de facilitar a informação:

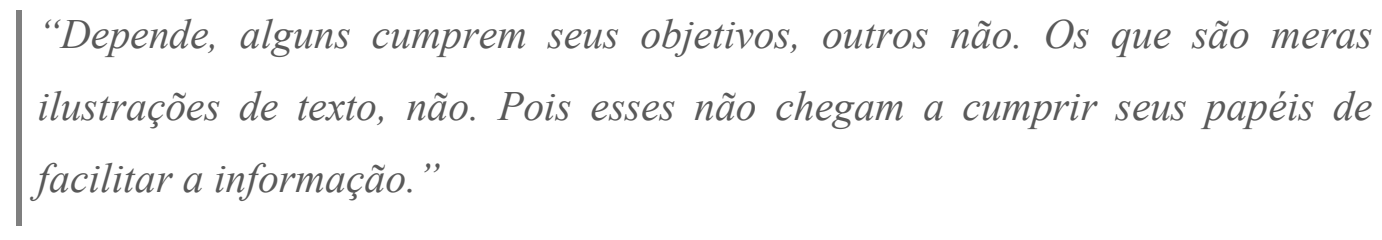

Para as perguntas "Geralmente há algum teste com usuários?" e "Geralmente há uma determinação de como será medido se o infográfico alcançou seu objetivo?", a grande maioria respondeu que não aplica testes com usuários para verificar se os infográficos atingem seus objetivos. Muitos disseram que há uma espécie de avaliação heurística ${ }^{17}$, com outros designers ou pessoas da equipe que fazem uma verificação prévia. Em alguns casos, o motivo para a ausência dos testes é o sigilo da informação antes da publicação oficial, como se pode perceber na fala de um entrevistado:

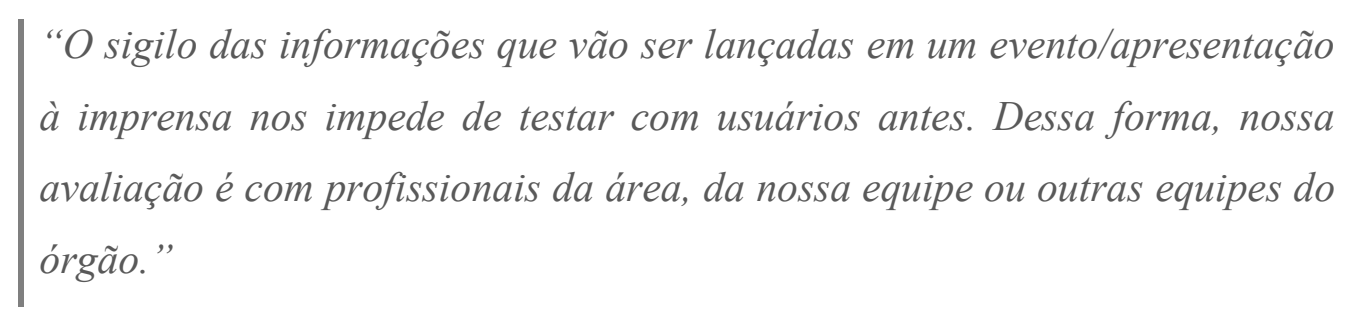

Observou-se neste capítulo quem é o profissional que elabora infográficos para o governo (em sua maioria jovens e sem vínculo direto com o governo), quais suas formações acadêmicas (e.g. publicitários e designers) e quais as dificuldades encontradas durante a elaboração dos infográficos (e.g. prazos curtos, falta de ferramentas, pressão quanto aos erros, falta de feedback de usuários, falta de interação com outros infografistas do governo).

A partir da análise das respostas, alguns resultados foram encontrados, conforme é relatado na próxima seção.

\subsection{ANÁLISE DOS RESULTADOS E DISCUSSÃO}

\footnotetext{
${ }^{17}$ Método de avaliação no qual especialistas identificam problemas numa interface, com base em um conjunto de princípios ou heurísticas.
} 
Quanto ao processo de elaboração de infográficos do governo, conclui-se pela entrevista com os infografistas que se tratam usualmente de sete atividades, não divididas em fases, descritas como:

1- estudo e análise do material recebido;

2- seleção do conteúdo;

3- busca de referências para leiaute e análise de similares;

4- criação de leiaute;

5- desenvolvimento de animação/interatividade (se for o caso);

6- avaliação da proposta pelos superiores e/ou área técnica; e

7- publicação.

Com a análise dos processos de elaboração estudados e com a comparação entre eles, foi produzida uma tabela contendo treze atividades, divididas em três fases, que contemplaria as atividades consideradas relevantes na literatura. Comparando-se as atividades dos infografistas com as atividades levantadas no estudo teórico, tem-se a seguinte tabela comparativa, com um X marcando as atividades mencionadas pelos entrevistados:

\begin{tabular}{|c|c|c|c|}
\hline \multirow[t]{5}{*}{$\begin{array}{l}\text { FASE DE } \\
\text { APURAÇÃO }\end{array}$} & № & ATIVIDADES & $\begin{array}{l}\text { RESULTADOS DA } \\
\text { ENTREVISTA }\end{array}$ \\
\hline & 1 & Identificar as necessidades e objetivos & $\mathrm{X}$ \\
\hline & 2 & Planejar prazos e atividades & \\
\hline & 3 & Pesquisar sobre o tema & $\mathrm{X}$ \\
\hline & 4 & Analisar similares & $X$ \\
\hline \multirow{3}{*}{$\begin{array}{l}\text { FASE DE } \\
\text { EXECUÇÃO }\end{array}$} & 5 & Elaborar conteúdo textual & $x$ \\
\hline & 6 & Idear e elaborar rascunhos & \\
\hline & 7 & Testar com usuários & \\
\hline
\end{tabular}




\begin{tabular}{|c|c|c|c|}
\hline & 8 & Elaborar o design & $x$ \\
\hline & 9 & Testar com usuários & \\
\hline & 10 & Revisar informações e fazer ajustes & $\mathrm{X}$ \\
\hline & 11 & Publicar & $x$ \\
\hline \multirow{2}{*}{$\begin{array}{l}\text { FASE DE PÓS- } \\
\text { PUBLICAÇÃO }\end{array}$} & 12 & Analisar o processo & \\
\hline & 13 & Testar com usuários & \\
\hline
\end{tabular}

Tabela 9: Comparação da tabela proposta com as respostas dos infografistas.

$\mathrm{Na}$ fase de apuração, os infografistas não são envolvidos nos planejamentos de prazos e atividades, o que significa que não há uma atividade com esse fim, que no estudo teórico foi identificada como "Planejar prazos e atividades". A maioria dos profissionais relatou que geralmente apenas recebem um prazo de entrega pré-determinado e precisam se adequar a ele, o que foi considerado por infografistas uma restrição na elaboração de um infográfico de qualidade.

O material que chega para análise muitas vezes é um conteúdo bruto, como uma lei pura, o que exigiria do profissional uma habilidade de compreensão de texto, uma vez que ele necessita de conhecimento suficiente para proporcionar embasamento ao seu processo criativo.

Na fase de execução, na atividade "Analisar similares", os infografistas não costumam fazer buscas em outros infográficos do governo, para reutilização de imagens, ícones, linguagens ou representações em geral. Isso ajudaria principalmente porque uma das dificuldades relatadas foi a da falta de ilustradores para desenhar ícones e imagens ou a falta de acesso a bancos de imagens não gratuitos, além de ser um caminho rumo à padronização de representações visuais.

Ainda na mesma fase, a atividade de elaborar de conteúdo textual nem sempre conta com a participação de um profissional com a expertise de escrever textos para a web, e 
em especial para infográficos. Muitas vezes essa função fica a cargo do infografista, o que exigiria do profissional uma habilidade de escrita objetiva e adequada. Esta habilidade é importante, sobretudo, porque de acordo com as premissas do governo, as informações devem estar dispostas de forma objetiva, transparente, clara e em linguagem de fácil compreensão.

A atividade "Elaborar o leiaute" é onde estaria a escolha das linguagens gráficas a serem utilizadas nos infográficos. Na entrevista observou-se que não há o costume de fazer rascunhos ou opções diferentes de visualização, o desenho final já é elaborado e proposto para avaliação dos superiores.

Não há testes com usuários antes da publicação, nem para a verificação dos textos, das imagens, nem para verificação do infográfico como um todo.

$\mathrm{Na}$ fase de pós-publicação, não há atividades de análise do processo, para melhorias. Também foi observado que não há atividades de testes com usuários após a publicação. Dessa forma, não há informações significativas sobre como os usuários compreendem os infográficos e se eles cumprem seus objetivos.

\subsection{CONSIDERAÇÕES FINAIS DO CAPÍTULO}

Observaram-se neste capítulo três processos de elaboração disponíveis na literatura e um estudo com profissionais que elaboram infográficos para o governo, elucidando quem são esses profissionais e como elaboram infográficos, investigando processos, atividades, anseios e dificuldades.

O capítulo a seguir trata de uma característica relacionada à atividade de elaborar design, constituinte da fase de execução, que é a escolha das linguagens gráficas dos infográficos. 


\section{LINGUAGEM GRÁFICA DE INFOGRÁFICOS}

No processo de elaboração de um infográfico, especificamente na fase determinada neste estudo como fase de execução, a atividade de elaborar o design é uma das mais importantes. Nessa atividade o infografista escolherá, dentre outras características, as propriedades formais que comporão o infográfico.

Esta seção expõe uma análise das propriedades formais de infográficos encontrados em sites do governo federal brasileiro, com base em uma matriz de classificação de linguagem gráfica. Acredita-se que, na fase de execução do infográfico, a escolha dos tipos de visualização para representação deve ser bastante criteriosa para alcançar o propósito comunicativo esperado (SOUTO, 2014). Com base nessa afirmação, este estudo foi realizado para investigar as características da linguagem gráfica usadas na infografia, com a intenção de identificar aspectos gráficos recorrentes na infografia digital no governo.

Este capítulo analisa os tipos de visualização adotados pelos infográficos do governo brasileiro. Primeiramente é apresentada a matriz de classificação de linguagem gráfica proposta por Twyman (1979), utilizada na análise dos infográficos. Em seguida é apresentado o estudo de caso escolhido - Portal Brasil, o método de seleção dos infográficos analisados e o resultado da análise das amostras.

\subsection{TWYMAN E A LINGUAGEM GRÁFICA}

$\mathrm{Na}$ busca por classificações de diagramas e métodos de visualização para utilizar como base neste estudo (e. g. BOUNFORD, 2000; LENGLER \& EPPLER, 2007), considerou-se que a matriz apresentada por Twyman (1979) se mostrou mais adequada para analisar os infográficos online do governo. Isso porque essa matriz engloba diferentes aspectos da linguagem gráfica utilizados na representação de tais infográficos.

Desse modo, este estudo parte do resultado da pesquisa de Twyman (1979), que construiu uma matriz que classifica e organiza as diversas soluções de representação da linguagem gráfica. A matriz é um esquema taxonômico construído pelo autor como um tutorial para os estudos de linguagem gráfica, e tem sido utilizada em pesquisas por diversos 
autores, como Horn (1999), Spinillo (2000) e Lima (2009). Twyman (1979) determina os eixos da matriz com dois conceitos: o método de configuração e o modo de simbolização. O objetivo da matriz era o de demonstrar esquematicamente as várias abordagens existentes na linguagem gráfica e, em seguida, identificar quais delas eram mais comumente adotadas. Segundo o autor, a matriz torna-se útil em situações práticas em que um designer precisa tomar decisões em relação a qual linguagem gráfica utilizar em determinada solução. A Tabela 10 representa uma adaptação da matriz.

\begin{tabular}{|l|l|l|l|l|l|l|l|}
\hline & Linear puro & $\begin{array}{c}\text { Linear } \\
\text { interrompido }\end{array}$ & Lista & $\begin{array}{c}\text { Linear } \\
\text { ramificado }\end{array}$ & Matriz & $\begin{array}{c}\text { Não-linear } \\
\text { direcionado }\end{array}$ & $\begin{array}{c}\text { Não-linear } \\
\text { não- } \\
\text { direcionado }\end{array}$ \\
\hline Verbal/numérico & 1 & 2 & 3 & 4 & 5 & 6 & 7 \\
\hline $\begin{array}{l}\text { Pictórico \& } \\
\text { verbal/numérico }\end{array}$ & 8 & 9 & 10 & 11 & 12 & 13 & 14 \\
\hline Pictórico & 15 & 16 & 17 & 18 & 19 & 20 & 21 \\
\hline Esquemático & 22 & 23 & 24 & 25 & 26 & 27 & 28 \\
\hline
\end{tabular}

Tabela 10: Matriz de Twyman (1979), adaptada e traduzida.

A matriz tem como colunas os métodos de configuração, que são descritos como a organização ou estrutura da mensagem. Essas estruturas determinariam as estratégias com as quais o usuário vai procurar, ler e olhar para uma mensagem. As categorias consideram as interrupções no fluxo linear de leitura e foram distribuídas em sete colunas. Elas variam da leitura puramente linear até a leitura não linear e não direcionada. São as colunas: Linear puro, Linear interrompido, Lista, Linear ramificado, Matriz, Não linear direcionado e Não linear não direcionado (aberto). As divisões das colunas são formadas por linhas sólidas, com exceção das últimas duas colunas, separadas por uma linha tracejada. Essa representação indica a subjetividade na separação das duas últimas categorias.

As linhas da matriz referem-se ao modo de simbolização. $\mathrm{O}$ autor as dividiu em quatro modos. São as linhas: Verbal/numérico, Pictórico \& verbal/numérico, Pictórico e Esquemático. Para o autor (TWYMAN, 1979), linguagens gráficas podem ser subdivididas em três categorias: verbal, pictórica e esquemática. As duas primeiras, segundo ele, não precisam de mais explicações além de que a categoria verbal engloba o uso de numerais e de outros caracteres convencionais. O autor, porém percebeu a necessidade de descrever a linguagem pictórica em detalhe (TWYMAN, 1982). O pictórico seria em português traduzido 
como figurativo. Ele descreveu "figura" como uma imagem feita à mão ou em máquina que, mesmo que distante, se refere à aparência ou estrutura de algo, com os propósitos descritivos ou narrativos. Já a terceira categoria, esquemática, engloba todos os tipos de marcas gráficas que não sejam palavras, números ou figuras.

Assim como na divisão das colunas, as duas últimas linhas são separadas por um tracejado. Isso se dá por conta da dificuldade que pode se estabelecer em classificar uma representação como pictórica ou esquemática. $\mathrm{O}$ autor menciona que não considerou as tipologias da linguagem pictórica (ícones ou símbolos), por não haver relação com o propósito da pesquisa.

Cada célula da matriz é um ponto de encontro entre linha e coluna e apresenta um número, de 1 a 28. Cada número de célula é representado por uma imagem de exemplo, que combina um modo de simbolização e um método de representação.

Twyman (1979) ressalta que na evolução histórica da linguagem gráfica é evidente que as linguagens no modo pictórico e esquemático tendem a se desenvolver em modos não-lineares, enquanto que a linguagem verbal e numérica se desenvolve de modo linear. $\mathrm{O}$ autor argumenta que duas perguntas principais devem ser o foco do designer gráfico que objetiva comunicar a mensagem de forma eficiente. São elas: “Qual deve ser o modo de simbolização?" e "Qual o método de configuração?”. Ele explica que vários fatores devem ser considerados para responder essas questões. Entre eles estão: "a natureza da mensagem a ser comunicada e para quem é direcionada, o efeito desejado e as considerações práticas como custo, tempo e meio de produção.” (1979:144). Também importante salientar que, conforme o autor argumenta, existem variantes da linguagem gráfica que não se encaixam especificamente em uma única célula da matriz, mas sim em uma combinação de características de células variadas.

Considerando as diretrizes acima como parâmetros para a análise dos infográficos, a amostra da pesquisa passou a ser definida. Foi escolhido o portal de entrada do governo federal para o estudo e os infográficos ali publicados foram selecionados aleatoriamente, para garantir uma amostra diversificada. Em seguida são descritas as amostras da análise.

\subsection{A ANÁLISE}

\subsubsection{AMOSTRAS DA ANÁLISE}


Para a definição do estudo de caso, composto de infográficos utilizados em sites do governo federal, foi considerado o site Portal Brasil. Esse site é o meio digital de convergência de canais e integração dos órgãos do Executivo federal, sendo considerado o portal de entrada do governo brasileiro. Sob a responsabilidade da Secretaria de Comunicação Social da Presidência da República (Secom) - que tem como premissa orientar a comunicação governamental de todos os órgãos do Poder Executivo na internet, por meio da Identidade Digital Padrão do Governo Federal - o site foi criado com o objetivo de facilitar a comunicação governamental entre o Estado e a opinião pública.

Os conteúdos das editorias do Portal Brasil constituem informações de interesse público e são apresentados por meio de textos, contextualizados e complementados com o auxílio de elementos multimídia como vídeos, imagens, áudios ou infográficos. Havia 99 infográficos publicados no site do Portal Brasil na ocasião desta pesquisa, em maio de 2014.

Para a definição das editorias do Portal Brasil, a Secom fez um alinhamento entre os principais assuntos e o projeto de Vocabulário Controlado de Governo Eletrônico (VCGE), que esquematiza e simplifica as palavras-chave, conhecidas como tags, mais utilizadas pelo governo federal na web. Há 12 assuntos mais utilizados (Cidadania e Justiça / Ciência e Tecnologia / Cultura / Defesa e Segurança / Economia e Emprego / Educação / Esporte / Governo / Infraestrutura / Meio Ambiente / Saúde / Turismo) e também tags específicas por assunto. Para exemplificar as tags específicas, a Figura 9 mostra o infográfico chamado "Agência regulamenta pré-pagamento eletrônico de energia elétrica", que traz como tags associadas: Infográfico, Pagamento eletrônico, Eletricidade, Luz, Luz pós-paga, Aneel e Arte gráfica.

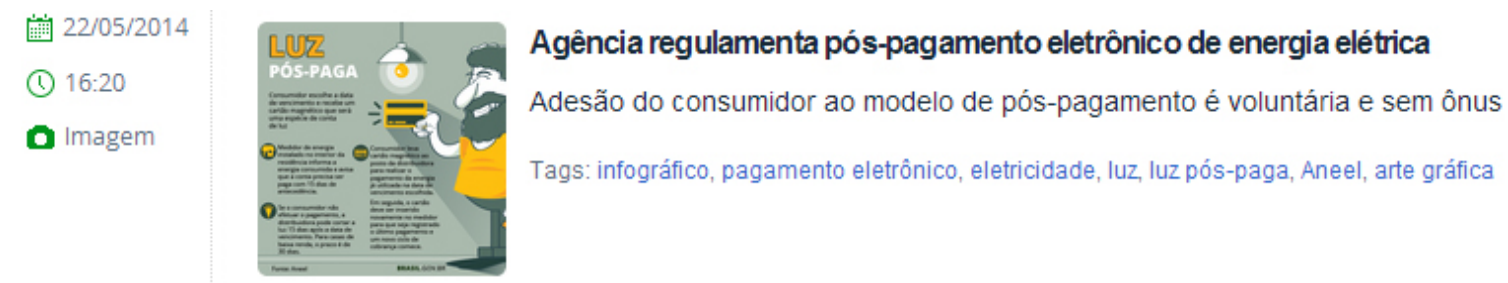

Figura 9: Exemplo de tags específicas de infográfico ${ }^{18}$.

No site Portal Brasil, o público pode escolher a forma pela qual pretende buscar o conteúdo desejado: por Estado do Brasil, por Planos e Programas, por Assunto e por Centrais

\footnotetext{
${ }^{18}$ Disponível em http://www.brasil.gov.br/centrais-de-conteudo/infograficos/ultimos-infograficos, acesso em maio 2014.
} 
de conteúdo. As centrais de conteúdos encontram-se divididas em Vídeos, Áudios, Infográficos, Aplicativos e Dados abertos.

$\mathrm{Na}$ área de Infográficos, a página inicial é denominada Central de Infográficos e mostra destaques de diversos assuntos com uma imagem, um título e um pequeno texto descritivo, como mostra a Figura 10. Ao clicar em um destaque, o usuário é levado para outra aba do navegador, que abre somente o infográfico em questão.

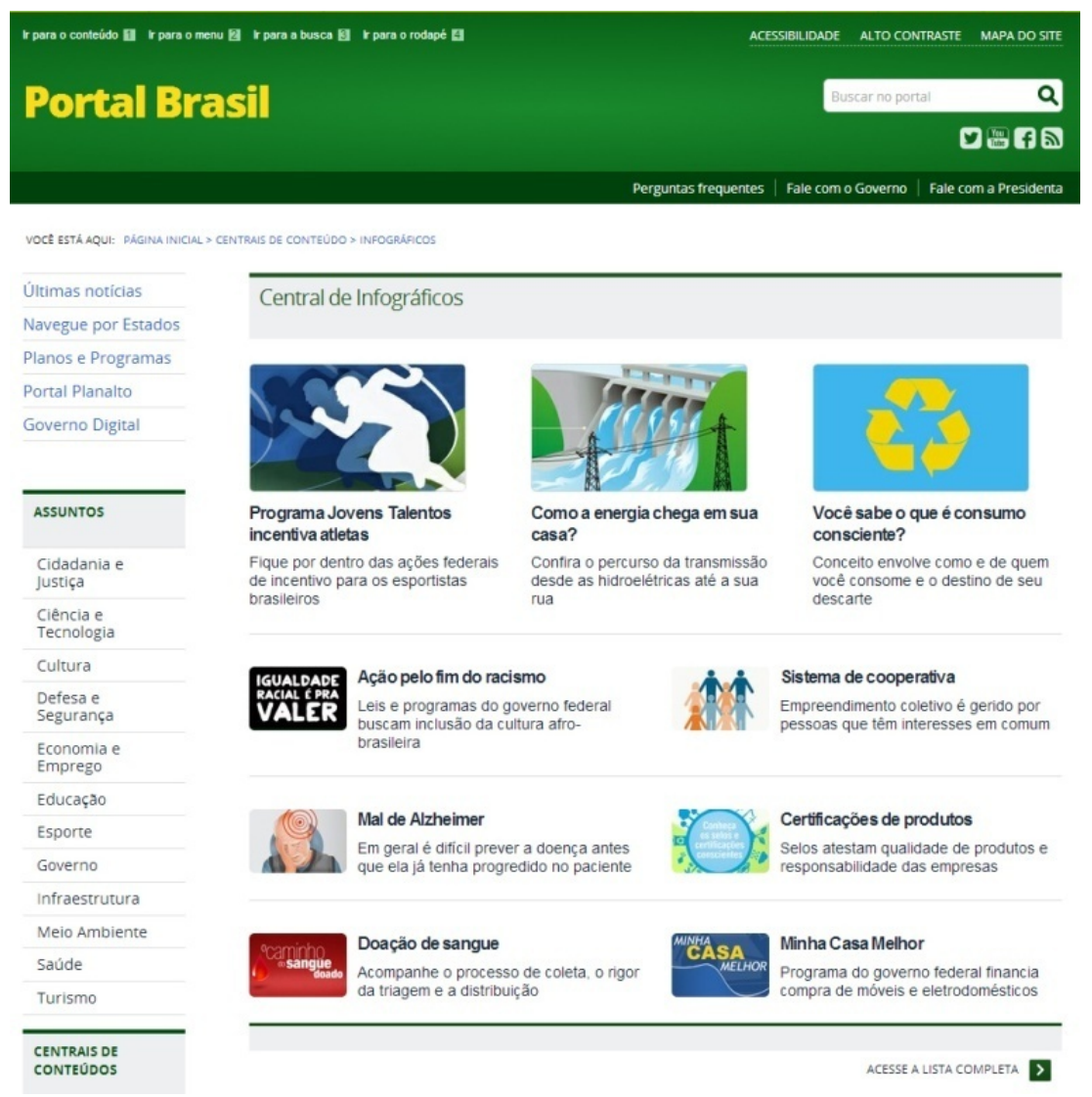

Figura 10: Imagem ilustrativa de parte da página da Central de infográficos do Portal Brasil ${ }^{19}$.

Na parte inferior desta página principal há um link para acessar a lista completa de infográficos. Nessa lista é possível ver todos os infográficos do site em ordem cronológica decrescente. Para cada infográfico há um título, uma imagem reduzida do infográfico, a data de publicação e as tags relacionadas, como já mostrado na Figura 9.

Dos 99 infográficos disponibilizados no site Portal Brasil na época do estudo, foi definido que seriam analisados vinte desses, sendo cinco infográficos do ano de 2014, cinco do ano de 2013, cinco no ano de 2012 e cinco de anos anteriores a 2012, que não continham

\footnotetext{
${ }^{19}$ Disponível em http://www.brasil.gov.br/centrais-de-conteudo/infograficos, acesso em maio 2014.
} 
data específica de publicação. A escolha dos cinco infográficos de cada grupo foi determinada de forma aleatória. Para isso, foi utilizada a ferramenta disponível no site Randomizer ${ }^{20}$, que permite a geração dinâmica de uma quantidade específica de números aleatórios.

A geração de números foi executada em 28 de maio de 2014, ocasião na qual havia sido publicada a seguinte quantidade de infográficos no Portal Brasil: 39 infográficos em 2014, dezessete em 2013, 22 em 2012 e 21 em anos anteriores. Os infográficos referentes a cada número gerado pela ferramenta estão descritos na Tabela 11 e alguns exemplos são mostrados nas Figuras 11 e 12.

\begin{tabular}{|c|c|c|}
\hline ANO & NOME & TAGS \\
\hline 2014 & Enem: entenda os critérios da prova & $\begin{array}{l}\text { Enem, Ministério da Educação, MEC, } \\
\text { Vestibular }\end{array}$ \\
\hline 2014 & $\begin{array}{l}\text { Conheça as categorias dos cursos do } \\
\text { Projovem }\end{array}$ & $\begin{array}{l}\text { Projovem, Capacitação, Formação de } \\
\text { Jovens }\end{array}$ \\
\hline 2014 & $\begin{array}{l}\text { Conheça todos os detalhes do Ciência sem } \\
\text { Fronteiras }\end{array}$ & $\begin{array}{l}\text { Ciência Sem Fronteiras, Bolsas no } \\
\text { Exterior }\end{array}$ \\
\hline 2014 & $\begin{array}{l}\text { Informe-se sobre o programa Patentes } \\
\text { Verdes }\end{array}$ & $\begin{array}{l}\text { INPI, Patentes Verdes, Tecnologias } \\
\text { Verdes }\end{array}$ \\
\hline 2014 & $\begin{array}{l}\text { Como retirar os ingressos da Copa do } \\
\text { Mundo }\end{array}$ & Ingresso, Retirada, Copa do Mundo \\
\hline 2013 & Bandeiras tarifárias & Energia, Bandeiras Tarifárias \\
\hline 2013 & $\begin{array}{l}\text { Confira a distribuição de jogos da Copa } \\
\text { das Confederações }\end{array}$ & Copa das Confederações 2013 \\
\hline 2013 & Igualdade racial é pra valer & Igualdade Racial \\
\hline 2013 & $\begin{array}{l}\text { Copa das Confederações movimenta } \\
\text { economia local das cidades-sede }\end{array}$ & Copa das Confederações, Economia \\
\hline 2013 & $\begin{array}{l}\text { Vai viajar para assistir aos jogos da Copa } \\
\text { das Confederações? }\end{array}$ & $\begin{array}{l}\text { Copa das Confederações, Pontos } \\
\text { Turísticos }\end{array}$ \\
\hline 2012 & Família chefiada por mulheres & $\begin{array}{l}\text { Cidadania e Justiça, Mulheres, } \\
\text { Família }\end{array}$ \\
\hline
\end{tabular}

\footnotetext{
${ }^{20}$ Disponível em http://www.randomizer.org, acesso em maio 2014.
} 


\begin{tabular}{|c|c|c|}
\hline 2012 & Mulheres na Política & $\begin{array}{l}\text { Cidadania e Justiça, Mulheres, } \\
\text { Política, Deputadas, Senadoras }\end{array}$ \\
\hline 2012 & Consciência sustentável no Brasil & Meio Ambiente, Impacto Ambiental \\
\hline 2012 & Economia de energia & Meio Ambiente, Economia, Energia \\
\hline 2012 & Aprenda a economizar água & Meio Ambiente, Água \\
\hline $\begin{array}{l}\text { Antes de } \\
2012\end{array}$ & Conheça os bens imateriais brasileiros & $\begin{array}{l}\text { Bens Imateriais, Patrimônio } \\
\text { Brasileiro, Iphan, Instituto do } \\
\text { Patrimônio Histórico e Artístico } \\
\text { Nacional }\end{array}$ \\
\hline $\begin{array}{l}\text { Antes de } \\
2012\end{array}$ & Caminho de Portugal na primeira fase & Sem Tags. \\
\hline $\begin{array}{l}\text { Antes de } \\
2012\end{array}$ & $\begin{array}{l}\text { Balanço de Vale-Cultura indica meio } \\
\text { milhão de beneficiados }\end{array}$ & $\begin{array}{l}\text { Vale-Cultura, Ministério da Cultura, } \\
\text { Minc }\end{array}$ \\
\hline $\begin{array}{l}\text { Antes de } \\
2012\end{array}$ & Confira como se deslocar em Natal & $\begin{array}{l}\text { Natal, Rio Grande do Norte, RN, } \\
\text { Copa 2014, Copa das Copas, Ônibus, } \\
\text { Metrô, Como se deslocar }\end{array}$ \\
\hline $\begin{array}{l}\text { Antes de } \\
2012\end{array}$ & Ciclo da Dengue & Saúde, Dengue, Ciclo, Mosquito \\
\hline
\end{tabular}

Tabela 11: Infográficos componentes da amostra da pesquisa. 


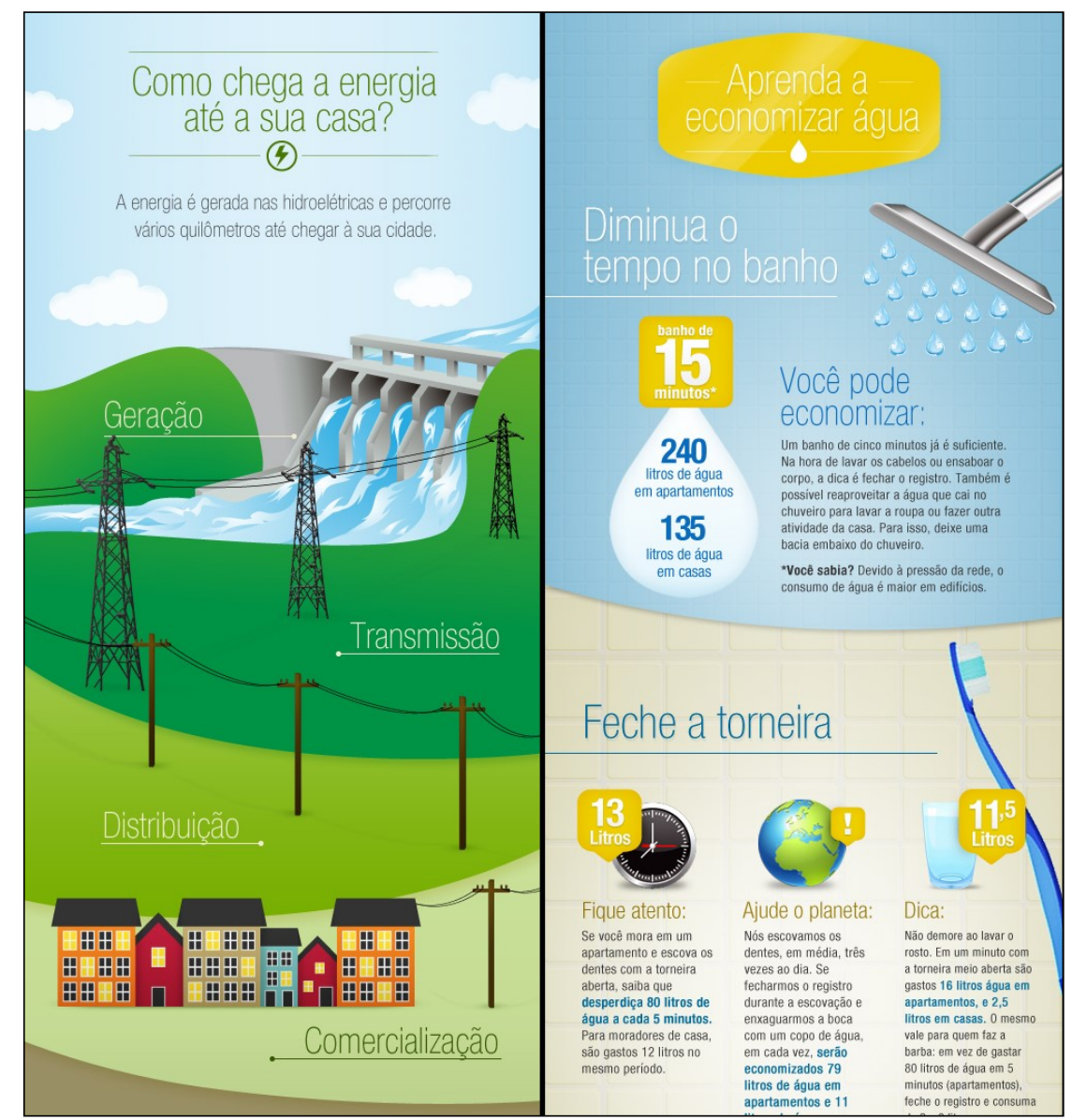

Figura 11: Exemplos de infográficos analisados: Política Tarifária e Aprenda a Economizar Água ${ }^{21}$.

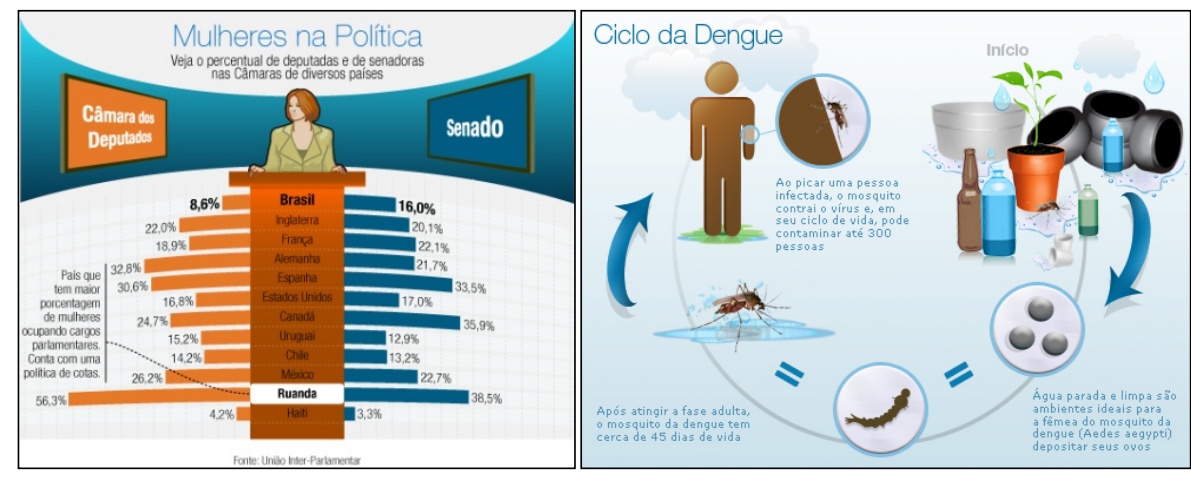

Figura 12: Exemplos de infográficos analisados: Mulheres na Política e Ciclo da Dengue ${ }^{22}$.

\footnotetext{
${ }^{21}$ Disponíveis em http://www.brasil.gov.br/infraestrutura/2011/12/politica-tarifaria-brasileira-garantequalidade-e-precos-acessiveis/bandeiras-tarifarias-1 e http://www.brasil.gov.br/meioambiente/2012/12/aprenda-a-economizar-agua, acesso em maio 2014.

${ }^{22}$ Disponíveis em http://www.brasil.gov.br/cidadania-e-justica/2012/04/mulheres_na_politica e http://www.brasil.gov.br/saude/2010/03/ciclo_da_dengue, acesso em maio 2014.
} 
Com a amostra definida, parte-se para a explanação da forma de análise determinada para o estudo.

\subsubsection{MÉTODO}

Muitos infográficos se utilizam de combinações de mais de uma linguagem gráfica em uma configuração híbrida, seja em termos de método de configuração ou de modo de simbolização (TWYMAN, 1979) ou de elementos usados para compor sintaticamente o infográfico (ENGELHART, 2002). Dessa forma, foi definido que a análise das suas propriedades seria feita primeiramente em relação à estrutura básica do infográfico, ou seja, da linguagem gráfica usada prioritariamente como solução. Em seguida, a análise seria dos detalhamentos utilizados na composição do infográfico.

Essa separação de estrutura e detalhamento surgiu da necessidade de explicitar as linguagens gráficas utilizadas. Em uma configuração híbrida, a solução gráfica principal é observada a primeira vista como um todo, e em seguida são lidos os segmentos, de forma direcionada ou não direcionada. Para a pesquisa das linguagens gráficas é relevante observar não somente como estas linguagens estão sendo utilizadas, mas também onde são utilizadas, seja na estrutura da composição (Figura 13) ou nos detalhes da composição (Figura 14).

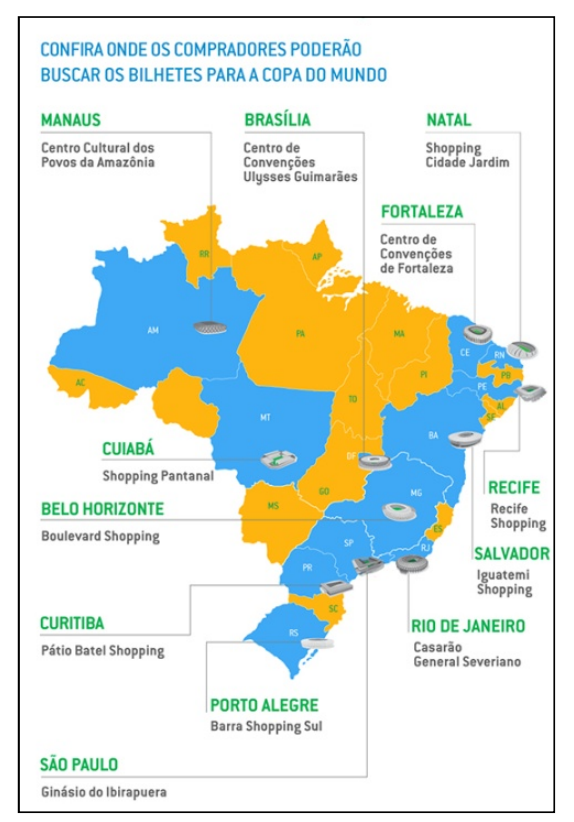

Figura 13: Exemplo de estrutura com linguagem da célula 28 (Não linear não direcionado e Esquemático) ${ }^{23}$.

\footnotetext{
${ }^{23}$ Disponível em http://www.brasil.gov.br/esporte/2014/05/centro-de-distribuicao-de-ingressos-para-a-copae-aberto/, acesso em maio 2014.
} 


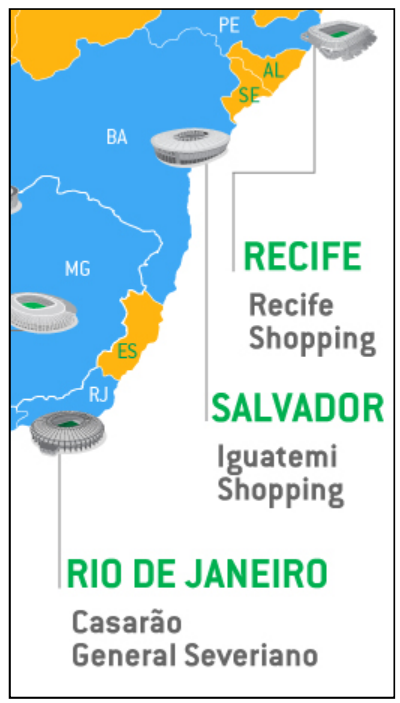

Figura 14: Exemplo de detalhamento com linguagem da célula 13 (Não linear direcionado e Pictórico \& verbal/numérico).

A análise dos infográficos foi efetuada iniciando-se pelas publicações mais antigas, em ordem cronológica, até às mais recentes. Cada ano recebeu uma matriz de análise para anotação dos dados. Cada infográfico da amostra definida é analisado primeiramente quanto à sua estrutura: Qual o principal modo de simbolização? Qual o principal método de configuração?

A partir da resposta anotada, uma célula é marcada com um "E". Em seguida, o mesmo infográfico é analisado em relação ao detalhamento, ou seja, das partes que o compõem, fazendo as mesmas perguntas para cada uma de suas partes. As respostas são anotadas e cada parte do infográfico recebe um " $D$ " em uma célula da tabela. Caso o infográfico repita no detalhamento uma linguagem já usada em sua estrutura, esta não é marcada duplamente, uma vez que a representação já consta na estrutura básica.

Para analisar as linguagens gráficas mais usadas na composição dos 20 infográficos, duas matrizes são apresentadas na Tabela 12. A primeira matriz apresenta em quais células se localizavam as estruturas dos infográficos (E). A segunda matriz apresenta as células referentes aos detalhamentos dos infográficos (D). As duas matrizes consideram os todos os vinte infográficos considerados na pesquisa. 


\begin{tabular}{|c|c|c|c|c|c|c|c|}
\hline \multicolumn{8}{|c|}{ TODAS AS AMOSTRAS - ESTRUTURA } \\
\hline & Linear puro & $\begin{array}{l}\text { Linear } \\
\text { interrompido }\end{array}$ & Lista & $\begin{array}{l}\text { Linear } \\
\text { ramificado }\end{array}$ & Matriz & $\begin{array}{l}\text { Não-linear } \\
\text { direcionado }\end{array}$ & $\begin{array}{c}\text { Não-linear } \\
\text { não- } \\
\text { direcionado }\end{array}$ \\
\hline Verbal/numérico & & & EE & & & EEE & \\
\hline $\begin{array}{l}\text { Pictórico \& } \\
\text { verbal/numérico }\end{array}$ & & & EEEE & & $\mathbf{E}$ & $\begin{array}{l}E \quad E \quad E \\
E E E E\end{array}$ & \\
\hline \multicolumn{8}{|l|}{ Pictórico } \\
\hline Esquemático & & & & & & E & \\
\hline \multicolumn{8}{|c|}{ TODAS AS AMOSTRAS - DETALHAMENTO } \\
\hline & Linear puro & $\begin{array}{c}\text { Linear } \\
\text { interrompido }\end{array}$ & Lista & $\begin{array}{l}\text { Linear } \\
\text { ramificado }\end{array}$ & Matriz & $\begin{array}{l}\text { Não-linear } \\
\text { direcionado }\end{array}$ & $\begin{array}{c}\text { Não-linear } \\
\text { não- } \\
\text { direcionado }\end{array}$ \\
\hline Verbal/numérico & & D D & $\begin{array}{l}\text { D D D } \\
\text { D D D }\end{array}$ & & D D D & & \\
\hline $\begin{array}{l}\text { Pictórico \& } \\
\text { verbal/numérico }\end{array}$ & & & D D D D & & D & D & \\
\hline Pictórico & & D & D & & D & & \\
\hline Esquemático & D D & D & & & & D & D D \\
\hline
\end{tabular}

Tabela 12: Matrizes adaptadas com as marcações de estrutura e detalhamento.

\subsubsection{RESULTADOS}

A análise das estruturas das amostras demonstra que a linguagem gráfica mais escolhida para os infográficos é o modo de simbolização Pictórico \& verbal/numérico, com ênfase no texto. Em segundo lugar o uso mais comum é o somente Verbal/Numérico. Não foi observada estrutura somente pictórica e apenas uma ocorrência de estrutura esquemática.

Muitos infográficos jornalísticos apresentam estruturas esquemáticas ou pictóricas como estrutura básica, contudo, estas não foram encontradas nos infográficos analisados.

O método de configuração mais usado nas estruturas é o não linear direcionado e, em seguida, a lista. Não foi identificado o uso de não linear não direcionado, linear ramificado, linear puro ou interrompido.

A análise dos infográficos quanto aos seus detalhamentos demonstra que mesmo nos segmentos usados para compor o infográfico, o modo de simbolização mais usado é Verbal e numérico, seguido de Pictórico \& verbal/numérico (com ênfase no texto), na mesma 
quantidade de Esquemático. Percebe-se o uso eventual de Pictórico puro. Quanto aos métodos de configuração, foram preferidas prioritariamente as listas, seguidas das matrizes e dos lineares interrompidos. As Figuras 15 e 16 mostram detalhes dos infográficos.

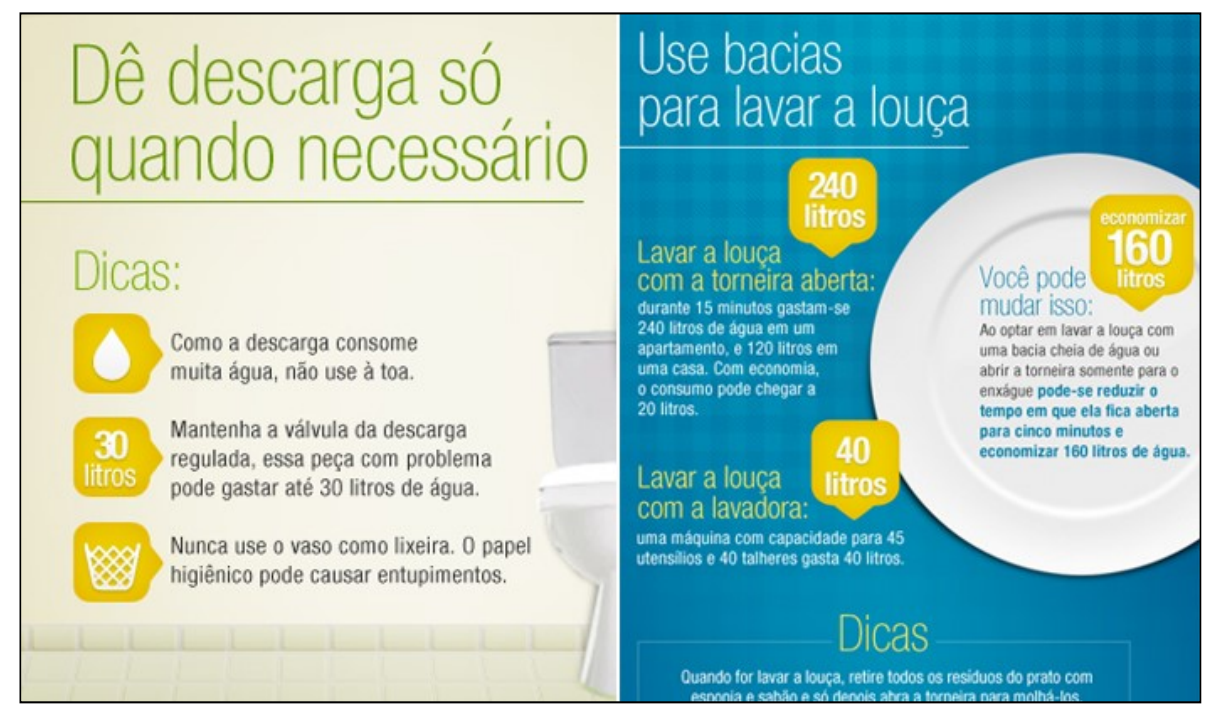

Figura 15: Detalhes de infográfico analisado, Aprenda a Economizar Água, com exemplo de uso dos métodos de configuração de listas (à esquerda) e não linear direcionado (à direita).

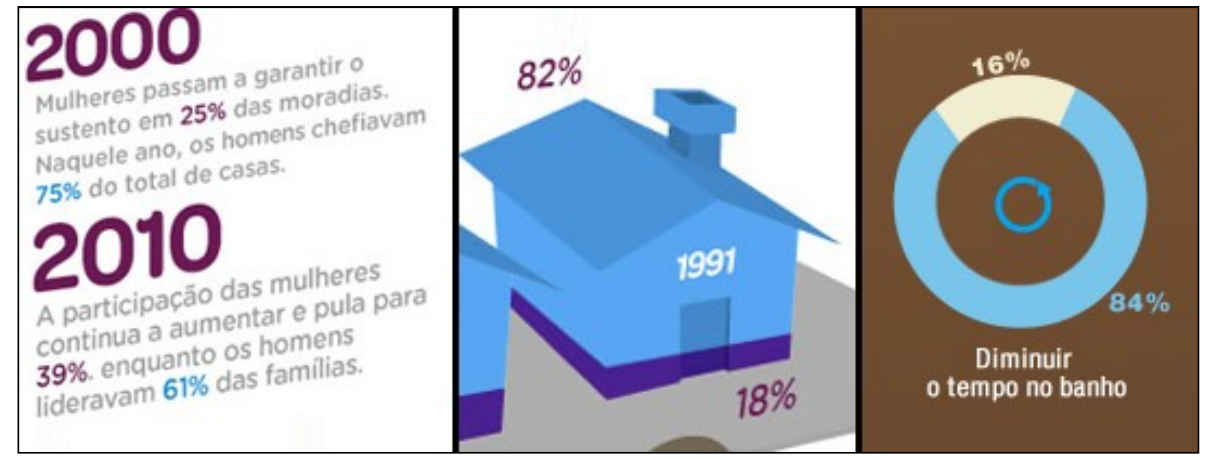

Figura 16: Detalhes de infográficos analisados, Famílias Chefiadas por Mulheres e Economia de Energia, com exemplo de uso dos modos de simbolização Verbal/numérico (à esquerda), Pictórico (centro), e Esquemático (à direita) ${ }^{24}$.

A comparação das amostras por ano de publicação não apresentou variação relevante. Pode-se concluir que não há nas amostras uma tendência de mudança nas soluções de linguagem gráfica, pelo contrário, a previsão é de que os modos e métodos preferidos permaneçam os mesmos. Este resultado está de acordo com a afirmação de Souto (2014), de

${ }^{24}$ Disponíveis em http://www.brasil.gov.br/cidadania-e-justica/2012/02/familia-chefiada-por-mulheres/view e http://www.brasil.gov.br/meio-ambiente/2012/10/energia-v3.jpg/view acesso em maio 2014. 
que os infográficos online ainda apresentam características dos infográficos impressos. Como ela explica: "conforme é visto em diversas áreas quando um novo formato é criado, a tendência inicial é imitar o anterior".

Em relação ao uso da matriz de Twyman para analisar infográficos online, ressalta-se que os modos de simbolização da matriz não consideram uma linha para a combinação de Esquemático com Verbal/numérico. Segundo afirmação do autor, não foram inseridas na matriz linhas próprias para uma combinação de Esquemático e Verbal/numérico, ou a distinção entre uma imagem composta de elementos discretos ou imagens sinópticas (termos descritos em seu artigo de 1982), para que estas adições não ofuscassem a questão importante que é o conflito nas estratégias de leitura desde a linearidade do modo verbal até a não linearidade dos modos pictórico e esquemático.

Compreende-se a razão justificada do autor. Contudo, verificou-se que, na análise de infográficos online, muitas vezes se utilizam modos verbais combinados com imagens esquemáticas. Muitas representações conhecidas, como: gráficos de pizza, de barras ou de linhas, encontram-se em diversos infográficos e compõem linguagem esquemática com apoio textual/numérico. Ressalta-se o modelo proposto por Twyman (1982) para acomodar as abordagens de linguistas e designers gráficos às linguagens. Nesse modelo, o autor subdivide as linguagens gráficas em categorias, sendo uma verbal, que inclui números e outros caracteres, e duas não verbais, pictórica e esquemática, conforme mostra a Figura 17:

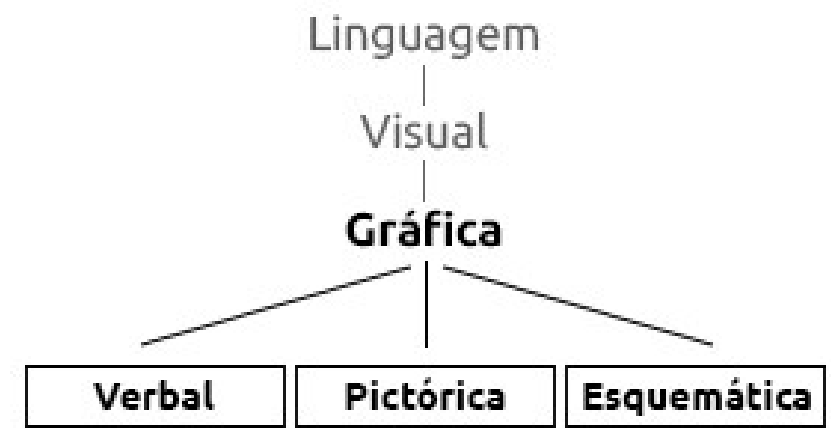

Figura 17: Parte do modelo de linguagens de Twyman (1985), adaptado e traduzido.

Ao definir o que é uma imagem (Picture, no original), Twyman (1982) reafirma a tênue linha que separa uma imagem pictórica de um esquema. Porém, no uso em infográficos, muitas vezes se encontra o uso claramente identificável como esquema ou pictórico puro.

Observando os exemplos de imagens de cada célula da matriz que o autor utiliza, vê-se que os exemplos de pictórico puro não trazem texto ou números, o que acontece em 
alguns dos exemplos esquemáticos. Mesmo considerando que os esquemas puros sejam de uso mais raro, e que a linguagem esquemática possivelmente precise de apoio escrito, seria plausível inserir uma linha específica para o item Esquemático \& verbal/numérico na matriz, provavelmente como a última linha da tabela, após o esquemático puro.

Como afirma Twyman, a intenção da matriz não é a de confinar ou definir a linguagem gráfica, mas demonstrar e identificar as várias abordagens existentes e dentre elas, as mais comumente adotadas. Dessa forma, vê-se a necessidade da adição da linha Esquemático \& verbal/numérico à matriz, para melhor identificação das linguagens utilizadas em infográficos, nos casos de imagens identificáveis como pictórica ou esquemática. Portanto, uma proposta de tabela modificada contaria com a inclusão da linha Esquemático \& verbal/numérico na matriz, conforme mostra a Tabela 13.

Ainda sobre a matriz, é importante observar que no uso do modo de simbolização que combina Pictórico com verbal/numérico, a ênfase pode ser no modo textual - com apoio de imagens pictóricas ou esquemáticas, ou a ênfase pode ser na imagem - trazendo apenas apoio textual. Reparar na ênfase existente no modo que combina texto com imagem pode trazer informações significativas quanto ao uso de linguagens gráficas.

Uma forma de identificar a ênfase na tabela, nas linhas que combinam textos e imagens, é indicar as letras "V" para verbal, "P" para pictórico ou "E" para esquemático. Na Tabela 13 está demonstrado o exemplo de uma matriz utilizada para marcação de estrutura. As linhas combinadas estão marcadas em cinza e simulam duas marcações de ênfase para cada linguagem: verbal (v), pictórica (p) e esquemática (e).

\begin{tabular}{|c|c|c|c|c|c|c|c|}
\hline \multicolumn{8}{|l|}{ ESTRUTURA } \\
\hline & Linear puro & $\begin{array}{l}\text { Linear } \\
\text { interrompido }\end{array}$ & Lista & $\begin{array}{l}\text { Linear } \\
\text { ramificado }\end{array}$ & Matriz & $\begin{array}{l}\text { Não-linear } \\
\text { direcionado }\end{array}$ & $\begin{array}{l}\text { Não-linear } \\
\text { não- } \\
\text { direcionado }\end{array}$ \\
\hline \multicolumn{8}{|l|}{ Verbal/numérico } \\
\hline $\begin{array}{l}\text { Pictórico \& } \\
\text { Verbal/numérico }\end{array}$ & $p p v v$ & & & & & & \\
\hline \multicolumn{8}{|l|}{ Pictórico } \\
\hline \multicolumn{8}{|l|}{ Esquemático } \\
\hline $\begin{array}{l}\text { Esquemático \& } \\
\text { verbal/numérico }\end{array}$ & e e v v & & & & & & \\
\hline
\end{tabular}


Tabela 13: Proposta de tabela modificada, a partir da matriz de Twyman (1979), acrescentando duas linhas e indicação da marcação de ênfase.

Com base nos resultados desta análise, pode ser concluído que os infográficos online disponibilizados pelo governo brasileiro apresentam modos de simbolização prioritariamente verbais, tanto na estrutura quanto nos detalhamentos. As estruturas têm em sua maioria métodos de configuração não direcionados, enquanto que os detalhamentos são organizados em listas ou matrizes.

Em referência a matriz de Twyman (1979) como base para identificação das linguagens gráficas utilizadas em infográficos online, sumariza-se a proposta de inclusão de uma linha para a combinação de esquemático e verbal/numérico, a indicação da ênfase (verbal ou imagético) em linguagens combinadas e a indicação da forma de aplicação da linguagem, se ela se dá na estrutura principal ou em um detalhamento.

Uma das expectativas dessa análise era a de encontrar interatividade nos infográficos, uma vez que a tecnologia possibilitaria interações multimídias diversas. Contudo, nenhuma das amostras selecionadas apresentou algum tipo de interatividade. Dessa forma, conclui-se que ainda não são aproveitadas as potencialidades digitais disponíveis.

A falta de interatividade nos infográficos online é um problema que já foi apontado por alguns autores. Manovich (2001) relata que, em contraste com as mídias tradicionais que são fixas, as novas mídias são não lineares e devem ser interativas, com objetos de interação que transformem o usuário em coautor do trabalho, e não mero receptor da informação. Já Souto (2014) ressalta que a falta de interatividade pode levar não só a uma inadequação do infográfico, como também limitar as possibilidades que a nova mídia apresenta. Dessa forma, espera-se que os infográficos tornem-se mais interativos num futuro breve.

\subsection{CONSIDERAÇÕES FINAIS DO CAPÍTULO}

Conclui-se que o governo brasileiro tem desenvolvido ações no sentido de auxiliar o acesso às informações digitais pelos cidadãos. Entretanto, verificou-se que esses infográficos configuram-se estáticos, não interativos, e que apresentam em linguagens gráficas prioritariamente verbais e de leitura não direcionada. 


\section{CONCLUSÕES E RECOMENDAÇÕES}

Este capítulo descreve as conclusões encontradas nos estudos, propõe uma lista de recomendações para auxiliar o governo e os infografistas a elaborarem infográficos de forma mais eficiente e eficaz e traz ao final as discussões e caminhos futuros a serem percorridos na área de infografia digital no governo brasileiro.

\subsection{CONCLUSÕES}

Observou-se nos levantamentos efetuados para este estudo uma série de considerações que, agregadas, levaram às conclusões desta pesquisa. Como início desta conclusão, apresenta-se a seguir um retrospecto dos estudos efetuados, para trazer à tona os pontos principais abordados aqui.

Constata-se que vivemos hoje em dia sob os efeitos de uma explosão informacional (BARRETO, 2010), na qual a quantidade de informação multiplica-se em progressão geométrica pelo aumento do uso de mídias digitais. A ansiedade informacional descrita por Wurman (2001) pode ser causada tanto pela sobrecarga de informação quanto pela informação suficiente, ou mesmo pela apresentação desorganizada ou representação inadequada, dentre outras variáveis.

Para resolver as questões da representação inadequada encontra-se a disciplina do design da informação, que para Jacobson (1999) é o arranjo sistemático e o uso dos elementos de comunicação para transmitir significado e aumentar entendimento entre as partes.

O design da informação é, portanto, uma área de atividade intimamente ligada à infografia e à visualização da informação (FASSINA, 2011). Infografia é considerada neste estudo como uma peça gráfica que utiliza simultaneamente a linguagem verbal gráfica, esquemática e pictórica, voltada prioritariamente à explicação de algum fenômeno (LIMA, 2009).

Este estudo tratou especificamente de infografia digital ou infografia online (ANDRADE, 2014), que são gráficos digitais que representam visualmente uma informação (SOUTO, 2014), publicados em websites do governo federal brasileiro. Observou-se que os infográficos começaram a popularizar os sites de governo para facilitar o acesso às informações, de acordo com os programas de Governo Eletrônico, o projeto de Identidade 
Digital de Governo e suas cartilhas e, mais ainda, com a Lei de Acesso à Informação, cujo Art. $5^{\circ}$ descreve que "É dever do Estado garantir o direito de acesso à informação, que será franqueada, mediante procedimentos objetivos e ágeis, de forma transparente, clara e em linguagem de fácil compreensão."

Das premissas percebidas nos estudos das publicações do governo quanto ao acesso à informação, concluiu-se as que devem ser consideradas na elaboração de infográficos, sendo elas: considerar que o ponto de partida do desenvolvimento é o usuário (cidadão); conhecer o usuário e seus comportamentos e desenvolver para que ele possa acessar a informação de forma clara e objetiva; garantir a acessibilidade das informações; e imprimir credibilidade e padronizar elementos.

Diante das premissas do governo sobre o acesso à informação, da presença dos infográficos em sites governamentais brasileiros e da ausência de estudos abordando os dois temas em conjunto, percebeu-se que não são conhecidos os processos sob os quais esses infográficos são elaborados e quais as ferramentas visuais empregadas em suas soluções, levando às perguntas desta pesquisa: (a) quais os processos de elaboração de infográficos digitais no governo; e (b) quais as linguagens gráficas neles utilizadas?

\subsubsection{QUAIS OS PROCESSOS DE ELABORAÇÃO DE INFOGRÁFICOS DIGITAIS NO GOVERNO?}

Para responder esta pergunta, foi elaborado inicialmente um estudo de processos de elaboração disponíveis na literatura, analisando as atividades propostas. Em seguida foi efetuada uma pesquisa com profissionais que elaboram infográficos para órgãos governamentais, a fim de conhecer os seus processos de elaboração e compará-los com os processos teóricos. Dessa forma, os processos de elaboração de infográficos digitais no governo foram identificados e em seguida foram analisados.

Como resposta à pergunta, concluiu-se que os processos de elaboração de infográficos digitais do governo usualmente são lineares e compostos de sete atividades, não divididas em fases, descritas como:

1- estudo e análise do material recebido;

2- seleção do conteúdo;

3- busca de referências para leiaute e análise de similares;

4- criação de leiaute;

5- desenvolvimento de animação/interatividade (se for o caso); 
6- avaliação da proposta pelos superiores e/ou área técnica; e

7- publicação.

A comparação dos processos da literatura (contendo treze atividades) com os processos praticados pelos infografistas (contendo sete atividades) mostrou que algumas atividades propostas na literatura não são seguidas na prática. Dessa forma, muitos pontos durante o processo podem ser aprimorados, para que a produção destes seja mais eficiente e para que os infográficos estejam mais adequados às premissas do governo quanto ao acesso à informação, de acordo com o estudo apresentado no início desta dissertação. Dentre os pontos a serem aprimorados, está a necessidade de atividades de testes com usuários. A lista de recomendações para os aprimoramentos no processo seguem na seção seguinte deste capítulo.

\subsubsection{QUAIS AS LINGUAGENS GRÁFICAS NELES UTILIZADAS?}

Esta pergunta foi respondida por meio da análise da linguagem gráfica de infográficos encontrados em sites do governo brasileiro, situando-os em uma matriz que compreende modos de simbolização e métodos de configuração.

Concluiu-se que, em relação às linguagens gráficas utilizadas em infográficos digitais do governo, o modo de simbolização mais utilizado nas estruturas é o Pictórico \& verbal/numérico, com ênfase no texto, seguido do modo Verbal/numérico puro. Já o método de configuração mais utilizado nas estruturas é o Não linear direcionado, e em seguida a Lista. Não foi identificado o uso de Não linear não direcionado, Linear ramificado, Linear puro ou interrompido.

$\mathrm{Na}$ análise dos infográficos quanto aos detalhamentos conclui-se que o modo de simbolização mais usado é o Verbal/numérico, seguido de Pictórico \& verbal/numérico (com ênfase no texto), na mesma quantidade de Esquemático. Quanto aos métodos de configuração nos detalhamentos, foram preferidas prioritariamente as listas, seguidas das matrizes e dos lineares interrompidos.

Nenhuma das amostras selecionadas apresentou algum tipo de interatividade, todas se constituíam de imagens estáticas. Não havendo interatividade em nenhuma das amostras analisadas, conclui-se que ainda não são aproveitadas as potencialidades digitais disponíveis.

A análise mostrou que as linguagens gráficas devem estar mais adequadas aos propósitos dos infográficos, equilibrando o uso de textos e imagens e direcionando a leitura do artefato de acordo com o objetivo do infográfico. Além disso, diante de linguagens 
prioritariamente verbais e de leitura não direcionada, testes com usuários devem ser feitos, para verificar o nível de efetividade dos infográficos.

\subsubsection{APLICAÇÕES DA PESQUISA}

Com base nos resultados dos estudos e nas conclusões descritas acima, uma lista de recomendações para a elaboração de infográficos do governo é proposta nesta dissertação, com o objetivo de aprimorar todo o processo de elaboração, desde o perfil do profissional e ambiente de trabalho até as atividades das fases do processo de elaboração, incluindo nelas a utilização das linguagens gráficas.

Mesmo esta pesquisa tendo seu foco na elaboração de infográficos do governo, considera-se que algumas das recomendações possam ser adaptadas e aplicadas em outros contextos de elaboração de infografia, como no desenvolvimento de infográficos por empresas privadas, e/ou na criação de infográficos para livros didáticos.

Na seção seguinte estão pontuadas as recomendações propostas nesta pesquisa, compostas por uma lista de doze itens.

\subsection{LISTA DE RECOMENDAÇÕES}

As recomendações são dirigidas ora ao governo, ora ao infografista, e seguem a ordem cronológica da elaboração de um infográfico desde antes do início do processo, quando governo e infografista precisam estar preparados para o início do trabalho. Elas estão explicadas e embasadas no texto a seguir e resumidas em uma tabela ao final.

\section{Ter habilidades e conhecimentos para elaborar infográficos de qualidade}

Recomenda-se que o infografista conheça determinados princípios de design da informação e de infografia, para o embasamento teórico na escolha das representações visuais da informação; e habilidades de compreensão de textos e dados estatísticos, uma vez que o material para elaborar o infográfico chega de formas brutas como leis, planilhas, etc., o que exige do profissional uma carga alta de compreensão e síntese. Ressalta-se que essas habilidades independem da formação acadêmica do profissional.

O referencial teórico proposto é composto de:

a. princípios de design da informação; 
b. linguagem gráfica; excelência gráfica e visualização da informação;

c. classificação e características de infográficos, visualizações de dados ou diagramas; e

d. compreensão de textos e dados estatísticos.

Recomenda-se que o governo atente-se para garantir que haja profissionais com habilidades para elaborar seus infográficos com qualidade, uma vez que os infográficos estão sendo utilizados cada vez mais nos sites de órgãos governamentais, de forma a produzirem informações mais claras e objetivas.

Esta recomendação baseia-se na afirmação de Jacobson (1999) sobre a responsabilidade moral do designer da informação e na de Horn (1999) sobre o poder interpretativo do designer da informação na missão de elucidar e clarear o sentido das coisas.

\section{Conhecer as premissas do governo relacionadas ao acesso à informação}

Recomenda-se que o infografista tenha conhecimento suficiente das premissas do governo quanto ao acesso à informação, atualizadas, para atentar-se às diretrizes que devem ser observadas na elaboração de infográficos do governo (e.g. Programa de Governo Eletrônico brasileiro, seus projetos e cartilhas, Lei de Acesso a Informações $n^{0} 12.527$ de 2011).

Esta recomendação baseia-se na legislação do governo sobre o acesso à informação e nas políticas, diretrizes e normas relacionadas às novas formas eletrônicas de interação.

\section{Planejar atividades com prazos que possibilitem a elaboração de infográficos de qualidade}

Recomenda-se que o governo garanta a existência de um planejamento de prazos para as atividades do infografista, com antecedência suficiente para que ele possa executar as atividades de forma a garantir um infográfico de qualidade, em especial nos casos de infográficos de maior relevância e de maior previsibilidade de publicação (e.g. campanhas de vacinação repetidas anualmente no mesmo mês). Nos casos em que ilustrações ou fotografias sejam indicadas para melhorar a compreensão do infográfico, o início da elaboração deve ser com antecedência suficiente para assegurar o tempo de execução.

Recomenda-se que o infografista identifique quais os temas tratados de forma recorrente pelo órgão governamental para o qual elabora infográficos e preparar um 
cronograma com os prováveis infográficos daquele ano, para uma organização inicial do seu planejamento.

Esta recomendação baseia-se na afirmação de Kanno (2103) sobre a importância da reunião dos envolvidos na elaboração de infográficos para o planejamento das atividades com base em um cronograma, e na consideração da maioria dos profissionais entrevistados que relatou que recebem um prazo de entrega e precisam adequar-se a ele sem planejamento prévio, considerado por eles uma restrição na elaboração de infográficos de qualidade.

\section{Utilizar elementos do repositório de infográficos do governo}

Recomenda-se que o governo crie um repositório para permitir que infografistas do governo salvem seus infográficos com as palavras-chave dos elementos que os compõem (e.g. ícone de receita federal, ícone de família, gráfico de distribuição de renda, fotos de cidades brasileiras), para que outros infografistas do governo possam reutilizar os mesmos elementos em outros órgãos, padronizando elementos utilizados recorrentemente no governo e otimizando o tempo de produção.

Sobre a padronização de elementos a serem reutilizados, recomenda-se que o governo padronize as assinaturas dos infográficos com os órgãos responsáveis e a fonte das informações, para que a credibilidade do governo seja conferida a todos os infográficos publicados nos sites dos seus órgãos e para que o cidadão tome ciência da fonte responsável pela criação.

Recomenda-se que o infografista, na atividade de analisar similares, considere os infográficos publicados por outros órgãos, para seguir um caminho de padronização e de otimização de tempo, considerando também a padronização do governo de assinaturas de infográficos mencionada acima.

Esta recomendação baseia-se na premissa da Identidade Digital de Governo de padronizar as propriedades digitais do Poder Executivo federal e nas observações da maioria dos infografistas entrevistados, que expuseram grande dificuldade em ter acesso a bancos de ícones e imagens para a elaboração dos infográficos. A recomendação baseia-se também em uma premissa das dez heurísticas para o design de interface, voltadas prioritariamente para a usabilidade de websites, em que Nielsen (1995) alega que a consistência e os padrões são relevantes, uma vez que o usuário não deve ter de ponderar se diferentes situações significam ou não a mesma coisa. Seguir as convenções ajudaria usuários a compreenderem melhor do que se tratam as informações. Ainda sobre a relevância da consistência, temos como base um 
item das linhas guia de Pettersson (2007), sobre facilitar o processo mental, em especial o processamento de figuras, recomendando o uso de imagens de forma consistente.

Foi considerada também na recomendação a premissa da Identidade Digital de Governo de imprimir credibilidade às informações disponíveis.

\section{Comunicar-se com infografistas do governo}

Recomenda-se que o governo crie um canal digital de comunicação (i.e. fórum online, grupo de e-mail, portal) para permitir que os infografistas do governo troquem informações sobre seus infográficos como testes com usuários, informações analíticas de monitoramento, para distribuir e aumentar o conhecimento entre os profissionais.

Esse canal possibilitaria que um infografista mantenha contato com outros infografistas do governo para trocar informações (e.g. métricas de acesso, lições aprendidas, sugestão de melhorias).

Esta recomendação baseia-se nas observações da maioria dos infografistas entrevistados, que expuseram a importância da comunicação com outros infografistas do governo e na dificuldade de estabelecer contato com eles.

\section{Redigir textos adequados}

Recomenda-se que o governo atente-se para garantir que exista, na equipe que elabora infográficos, um profissional que execute a função de redator web, com a habilidade de escrever textos de forma objetiva, transparente, clara e em linguagem de fácil compreensão. Este profissional pode ou não ser o próprio infografista.

Esta recomendação baseia-se no Art. 5o da LAI: "É dever do Estado garantir o direito de acesso à informação, que será franqueada, mediante procedimentos objetivos e ágeis, de forma transparente, clara e em linguagem de fácil compreensão."

\section{Aplicar linguagens gráficas adequadas}

Recomenda-se que o infografista, na atividade de elaborar o design, escolha a linguagem gráfica apropriada ao público que vai acessá-lo. Ele deve observar os modos de configuração e métodos de configuração que vai usar, balanceando a utilização de modo verbal e numérico com pictórico ou esquemático, e configurando o método de leitura que esteja mais adequado ao propósito do infográfico. 
Esta recomendação baseia-se na afirmação de Twyman (1979) de que a linguagem gráfica deve ser o foco do designer gráfico que objetiva comunicar a mensagem de forma eficiente e a de Tufte (2001) de que a excelência gráfica é o que garante o entendimento universal das visualizações de informação.

\section{Garantir a acessibilidade dos infográficos}

Recomenda-se que o infografista, na atividade de publicação, assegure-se de que o infográfico, estático ou não, esteja de acordo com o modelo de acessibilidade do governo mais atualizado (e.g. mostrando as informações em texto de sistema e descrevendo as imagens no código da página onde está publicado).

Esta recomendação está relacionada à recomendação 2, e baseia-se especificamente na premissa do governo descrita na e-MAG - Modelo de Acessibilidade de Governo Eletrônico, de que imagens mais complexas como infográficos forneçam a descrição destes no próprio contexto ou um link para a descrição longa logo após as imagens. Pela relevância do tema, esta recomendação recebeu um item destacado.

\section{Revisar infográficos antes da publicação}

Recomenda-se que o infografista garanta que seja cumprida, sem falta, a atividade de revisar informações (i.e. textos, números, imagens) e fazer ajustes, contando com um revisor que não ele próprio, para corrigir erros antes da publicação e assegurar a credibilidade do governo na divulgação de informações.

Esta recomendação baseia-se na premissa da Identidade Digital de Governo de imprimir credibilidade às informações disponíveis e nas observações da maioria dos infografistas entrevistados, que expuseram a importância do infográfico de informação oficial ser publicado sem erros.

\section{Testar infográficos antes da publicação}

Recomenda-se que o governo possibilite, na medida do possível, meios para que os infográficos possam ser testados pelos infografistas antes da publicação.

Recomenda-se que o infografista, após as atividades de elaborar conteúdo textual e elaborar design, com o infográfico pronto e em uma versão inicial antes da publicação, efetue testes de compreensão com usuários, para verificar se o infográfico está cumprindo seus objetivos ou se necessita de ajustes para ser publicado. Os testes devem verificar a 
compreensão dos modos verbais/numéricos e dos pictóricos/esquemáticos. As atividades de ajustar e testar devem seguir iterativamente até que o infográfico esteja cumprindo o objetivo esperado e possa ser publicado. Esse teste não será possível nos casos de necessidade de sigilo da informação do infográfico antes da sua publicação.

Esta recomendação baseia-se na afirmação de Gaffney (1999) sobre testes serem aplicados antes da publicação, para garantir que questões significantes sejam identificadas e corrigidas, e nos processos teóricos analisados (i.e. Sless, 2008; Carvalho e Aragão, 2012 e Kanno, 2013). Baseia-se também nas premissas do governo de considerar que o ponto de partida do desenvolvimento é o usuário.

\section{Monitorar infográficos publicados}

Recomenda-se que o governo possibilite que os infográficos sejam acompanhados após a publicação por meio de ferramentas analíticas e de métricas de acesso, de forma a saber o contexto da utilização, ou seja, de onde o cidadão acessa, em que ambiente e em que condições.

Recomenda-se que o infografista, após a publicação, na atividade de testar com usuários em uma fase de pós-publicação, verifique de que forma o cidadão recebeu o infográfico publicado no site. Ele deve monitorar os dados analíticos de acesso ao infográfico, para medir e analisar métricas (e.g. tempo de leitura, taxa de rejeição, etc.) e considerá-las na elaboração dos próximos infográficos.

Esta recomendação baseia-se nas premissas do governo de conhecer, entender e trabalhar com as pessoas que representam os atuais e potenciais utilizadores do produto (cidadãos) e saber o contexto da utilização; e na afirmação de Souto (2014) sobre o entendimento de como o público interage com o infográfico parecer indicar um dos aspectos para a criação de gráficos de excelência.

\section{Rever o processo de elaboração do infográfico e aplicar melhorias}

Recomenda-se que o infografista, ao final de cada processo de elaboração, reveja como se deu todo o processo e verificar se algo poderia ser melhorado, buscando formas de executar essas melhorias. Caso a melhoria possa ser aproveitada por outros infografistas, ela deve ser inserida no canal digital de comunicação, para conhecimento.

Esta recomendação baseia-se no argumento de que compreender processos é relevante para auxiliar no progresso e na eficiência dos produtos (HOWARD ET AL., 2006). 
Elaborou-se uma tabela com o resumo das recomendações, com a indicação do direcionamento de cada uma (i.e governo e/ou infografista).

\begin{tabular}{|c|c|c|c|}
\hline № & RECOMENDAÇÃO & PARA O GOVERNO & PARA O INFOGRAFISTA \\
\hline 1 & $\begin{array}{l}\text { Ter habilidades e conhecimentos para } \\
\text { elaborar infográficos de qualidade. }\end{array}$ & $\mathrm{X}$ & $\mathrm{X}$ \\
\hline 2 & $\begin{array}{l}\text { Conhecer as premissas do governo } \\
\text { relacionadas ao acesso à informação. }\end{array}$ & & $\mathrm{X}$ \\
\hline 3 & $\begin{array}{l}\text { Planejar atividades com prazos que } \\
\text { possibilitem a elaboração de infográficos } \\
\text { de qualidade. }\end{array}$ & $\mathrm{X}$ & \\
\hline 4 & $\begin{array}{l}\text { Utilizar elementos do repositório de } \\
\text { infográficos do governo. }\end{array}$ & $\mathrm{X}$ & $\mathrm{X}$ \\
\hline 5 & $\begin{array}{l}\text { Comunicar-se com infografistas do } \\
\text { governo. }\end{array}$ & $\mathrm{x}$ & $\mathrm{X}$ \\
\hline 6 & Redigir textos adequados. & $\mathrm{X}$ & $\mathrm{X}$ \\
\hline 7 & Aplicar linguagens gráficas adequadas. & & $\mathrm{X}$ \\
\hline 8 & Garantir a acessibilidade dos infográficos. & & $\mathrm{x}$ \\
\hline 9 & Revisar infográficos antes da publicação. & & $\mathrm{X}$ \\
\hline 10 & Testar infográficos antes da publicação. & $\mathrm{x}$ & $\mathrm{x}$ \\
\hline 11 & Monitorar infográficos publicados. & $\mathrm{X}$ & $\mathrm{X}$ \\
\hline 12 & $\begin{array}{l}\text { Rever o processo de elaboração do } \\
\text { infográfico e aplicar melhorias. }\end{array}$ & & $\mathrm{X}$ \\
\hline
\end{tabular}

Tabela 14: Lista resumida de recomendações

Espera-se que essas recomendações sirvam de embasamento para que tanto governo quanto infografistas possam aprimorar a elaboração de infográficos e garantir, 
consequentemente, que o cidadão possa se informar por meio de infográficos digitais de qualidade.

\subsection{PESQUISAS FUTURAS}

Como perspectiva futura, seria relevante efetuar testes com cidadãos para verificar a eficácia e eficiência dos infográficos publicados em sites do governo. Isso se deve pois, ao obter as respostas das duas perguntas deste estudo, verificou-se a necessidade de efetuar testes que verifiquem o resultado dos infográficos digitais em sites do governo. Ademais, a revisão da literatura mostrou que as pesquisas ainda não focam em estudos empíricos que tem como objetivo verificar como se dá a interação do usuário com os infográficos online. Alguns autores (e.g. DICK, 2013) já apontaram a necessidade de tais investigações, assim como Pettersson (2007) cita em várias linhas guias a necessidade do entendimento e do envolvimento do público-alvo na criação de informação gráfica. O entendimento de como o público interage com o infográfico parece ser um dos aspectos para a criação de gráficos de excelência (SOUTO, 2014). Os testes podem incluir uma série de questões, como: como se dá a compreensão dos usuários desses infográficos? Os cidadãos gostam de ler os infográficos, mais do que os textos corridos? Os infográficos que se apresentam por modos mais verbais e numéricos estariam sendo usados para transmitir conteúdos muito extensos? Como os cidadãos percebem infográficos de linguagens gráficas diferentes?

Seria também relevante verificar a acessibilidade dos infográficos estáticos e questionar a relação entre a falta de infográficos interativos no governo e a acessibilidade.

Com essas verificações haveria mais conhecimento para a criação de infográficos de excelência, que permitam o acesso à informação de forma clara e objetiva, como indicam as diretrizes do governo. 


\section{REFERÊNCIAS BIBLIOGRÁFICAS}

ANDRADE, R. C. Infográficos animados e interativos em saúde. Um estudo sobre a compreensão de notícias. 2014. 160 f. Dissertação (Mestrado em Design) - UFPR, Recife, 2014.

BARRETO, J. S. A perfeição do nada: da videologia à desideologia da percepção. In: Jaime Robredo; Marisa Bräscher (Orgs.). Passeios no Bosque da Informação: Estudos sobre Representação e Organização da Informação e do Conhecimento - EROIC. Brasília DF: IBICT, 2010. 335 p. ISBN: 978-85-7013-072-3. Capítulo 2, p. 48-59. Edição eletrônica. Disponível em: $<$ http://www.ibict.br/publicacoes/eroic.pdf>. Acesso em: 20 Dez. 2014.

BAXTER, M. Product design. New York: CRC Press, 1995.

BONI, V., \& QUARESMA, S. J. Aprendendo a entrevistar: como fazer entrevistas em Ciências Sociais. Santa Catarina: Em Tese, 2005. 2(1), 68-80. Disponível em: $<$ https://periodicos.ufsc.br/index.php/emtese/article/view/18027>. Acesso em: 15 Set. 2015.

BONSIEPE, G.; KELLNER, P.; POESSNECKER, H. Metodologia experimental. Brasília: CNPq, 1984.

BOUNFORD, T.; CAMPBELL, A. Digital Diagrams: How to Design \& Present Statistical Information Effectively. New York: Watson-Guptill, 2000.

BRASIL. Constituição (1988). Constituição da República Federativa do Brasil. Brasília, DF: Senado Federal: Centro Gráfico, 1988.

. LEI No. 12.527, de 18 de novembro de 2011. Regula o acesso a informações. Diário Oficial da União, Brasília, 19 nov. 2011. Disponível em: $<$ http://www. planalto. gov. br/ccivil_03/_Ato20112014/2011/Lei L 12527>. Acesso em: 10 Dez. 2014.

. Modelo de Acessibilidade em Governo Eletrônico. Ministério do Planejamento, Orçamento e Gestão, Secretaria de Logística e Tecnologia da Informação. Brasília, 2010. Disponível em: $<$ http://www.governoeletronico.gov.br/acoes-e-projetos/e-MAG>. Acesso em: 10 Dez. 2014.

Padrões $W e b$ em Governo Eletrônico: Cartilha de Usabilidade. Ministério do Planejamento, Orçamento e Gestão, Secretaria de Logística e Tecnologia da Informação. Brasília, 2010. Disponível em: <http://epwg.governoeletronico.gov.br/cartilha-usabilidade>. Acesso em: 10 Dez. 2014.

BUARQUE, A. H. F. Dicionário Aurélio Básico da Lingua Portuguesa. São Paulo: Folha de São Paulo/ Nova Fronteira, 1994.

CAIRO, A. Coberturas infográficas de actualidad imediata. Madrid: Alzado, 2004. Disponível em: < http://www.alzado.org/articulo.php?id_art=401> Acesso em: 12 Set 2014.

Infografia 2.0: Visualización interactiva de información en la prensa. Madrid: Alamut,

2008. 
CARVALHO, J; ARAGÃO, I. Infografia: Conceito e Prática. São Paulo: InfoDesign, v. 9 n. 3, p. 160 $-177.2012$.

DESIGN COUNCIL. Double Diamond. Londres, 2006. Disponível em:

$<$ http://www.designcouncil.org.uk/news-opinion/design-process-what-double-diamond $>$. Acesso em:

7 Dez. 2014.

DIAS, C. A. Método de avaliação de programas de governo eletrônico sob a ótica do cidadão-cliente: uma aplicação no contexto brasileiro. 2006. 277 f. Tese (Doutorado em Ciência da Informação) Universidade de Brasília, Faculdade de Economia, Administração, Contabilidade e Ciência da Informação e Documentação, Departamento de Ciência da Informação e Documentação, Brasília, 2006.

DICK, M. Interactive infographics and news values. Digital Journalism. Routledge, 2013.

DUR, B. Analysis of Data Visualizations in Daily Newspapers in Terms of Graphic Design. In:

Procedia - Social and Behavioral Sciences, Vol. 51. p. 278-283, 2012.

ENGELHARDT, J. V. et al. The language of graphics. Amsterdam: Sewn, 2002. Disponível em: http://dare.uva.nl/document/66041. Acesso em: 3 Dez. 2014.

FASSINA, U. A infografia como recurso comunicacional no processo de aquisição de informação e compreensão de tipografia. 2011. 95 f. Dissertação (Mestrado em Comunicação) - Universidade Estadual de Londrina, Londrina, 2011.

FRASCARA, J. ¿Qué es el diseño de informacion? Argentina: Infinito, 2011.

FREITAS, R. F.; COUTINHO, S. G.; WAECHTER, H. N. Análise de Metodologias em design: a informação tratada por diferentes olhares. Estudos em Design | Revista (online). Rio de Janeiro: v. 21, n. 1. 2013.

GAFFNEY, G. Usability Testing. Information \& Design. Australia, 1999. Disponível em: < http://infodesign.com.au/usabilityresources/usabilitytesting>. Acesso em: 3 Maio 2015.

HORN, R. Information Design: The Emergence of a New Profession. In: JACOBSON, R. (Ed.). Information Design. Cambridge: The MIT Press, 1999.

HOWARD, T.J.; CULLEY S.J.; DEKONINCK E. Describing the creative design process by the integration of engineering design and cognitive psychology literature. In: Design Studies v.29, n.2: 160-180, 2006.

IDX. Information Design Exchange. Information Design: What information designers know and can do. Vienna, 2007. Disponível em: <http://www.iiid.net/idx-information-design-core-competencies/>. Acesso em: 29 Out. 2015.

IIID. International Institute for Information Design. Definitions. Vienna, 2000. Disponível em: $<$ http://www.iiid.net/home/definitions/>. Acesso em: 29 Out. 2015.

KANNO, M. Infografe: Como e porque usar infográficos para criar visualizações e comunicar de forma imediata e eficiente. São Paulo: Infolide, 2013. Disponível em:

$<$ http://www.infolide.com/2013/08/infografe-o-novo-livro-de-infografia-de.html >. Acesso em: 23

Mar. 2015. 
KAFURE, I. Usabilidade da imagem na recuperação da informação no catálogo público de acesso em linha. 2004. 311 f. Tese (Doutorado em Ciência da Informação) - Universidade de Brasília, Departamento de Ciência da Informação e Documentação, Brasília, 2004.

LANA S. 2011. A complexidade dos métodos em design. Cadernos de Estudos Avançados em Design. EdUEMG. Barbacena, MG, 2011. Disponível em:

$<$ http://www.tcdesign.uemg.br/pdf/Metodo_completo.pdf $>$. Acesso em: 12 Dez. 2014.

LENGLER, R., \& EPPLER, M. J. Towards a periodic table of visualization methods for management. In: IASTED Proceedings of the Conference on Graphics and Visualization in Engineering (GVE 2007). Clearwater, Florida, USA, 2007.

LIMA, R. C. Análise da infografia jornalística. 2009. 143 f. Dissertação (Mestrado em Design) ESDI/UERJ, Rio de Janeiro, 2009.

LÖBACH, B. Desenho Industrial - Base para configuração dos produtos industriais. São Paulo: Edgar Blücher, 2000.

MACK, N., WOODSONG, C., MACQUEEN, K. M., GUEST, G., \& NAMEY, E. Qualitative Research Methods: a Data Collectors Field Guide. Massachusetts, 2005. Disponível em: $<\mathrm{http} / / /$ www.ccs.neu.edu/course/is4800sp12/resources/qualmethods.pdf $>$ Acesso em: 15 Dez. 2014.

MANOVICH, L. The language of new media. MIT Press, 2001.

MEIRELLES, I. Design for Information: An Introduction to the Histories, Theories, and Best Practices Behind Effective Information Visualizations. Rockport Publishers, 2013.

MOGGRIDGE, B. Innovation through design. In: International design culture conferenceCreativeness by Integration. Kyoto, Japan, 2008.

MORAES, A. Infografia - O design da notícia. Dissertação. 1998. 173 f. Dissertação (Mestrado em Design) - PUC-RJ, Rio de Janeiro, 1998.

NIELSEN, J. 10 usability heuristics for user interface design. Fremont: Nielsen Norman Group, 1995. Disponível em: < http://www.nngroup.com/articles/ten-usability-heuristics> Acesso em: 19 Out. 2015.

PANIZZA, J.F. Metodologia e processo criativo em projetos de comunicação visual. 2004. $254 \mathrm{f}$. Dissertação (Mestrado em Comunicação) - USP, São Paulo, 2004.

PETTERSSON, R. It Depends: Information Design - Principles and Guidelines. Tullinge, Sweden, 2007.

PHILLIPS, P. L. Briefing: a gestão do projeto de design. Blucher, 2008.

RAJAMANICKAM, V. Infographics seminar handout. In: Seminars on Infographic. Design, National Institute of Design, Ahmedabad, and the Industrial Design Centre, Indian Institute of Technology, Bombay. 2005. Disponível em: < http://www.as8.it/handouts/infographic.pdf > . Acesso em: 18 Mar. 2015.

RIBEIRO, D. M. Visualização de dados na internet. 2009. 132 f. Dissertação (Mestrado em Tecnologias da Inteligência e Design Digital) - Pontifícia Universidade Católica de São Paulo, São Paulo, 2009. 
RIECKEN, R. A contemporaneidade do tema governo eletrônico e perspectivas de pesquisas. In: Jaime Robredo; Marisa Bräscher (Orgs.). Passeios no Bosque da Informação: Estudos sobre Representação e Organização da Informação e do Conhecimento - EROIC. Brasília, DF: IBICT, 2010. 335 p. Capítulo 13, p. 294-319. Edição eletrônica. Disponível em: $<$ http://www.ibict.br/publicacoes/eroic.pdf>. Acesso em: 12 Dez. 2014.

SANCHO, J. L. V. La infografia: técnicas, análisis y usos periodístios. Barcelona: Universitat Autónoma de Barcelona, 2001.

SANTOS, R. L. G. dos. Abordagem heurística para avaliação da usabilidade de interfaces. In: MORAES, A. (org.). Design e avaliação de interface. Rio de Janeiro: iUsEr, 2002.

SLESS, D. Measuring information design, Information Design Journal, vol. 16, no. 3, pp. 250-258, 2008 .

SOCIEDADE BRASILEIRA DE DESIGN DA INFORMAÇÃO. Brasil. Disponível em: <sbdi.org.br>. Acesso em: 12 Dez. 2014.

SIRICHAROEN, W. V. Infographics: The New Communication Tools in Digital Age. In: Proceedings of the International Conference on E-Technologies and Business on the Web (EBW2013) - Thailand, 2013.

SOUTO, V. Infografia jornalística online: princípios de comunicação e design. Anais da $4_{-}^{\mathrm{a}}$ Conferência ICA América Latina, Brasília, 2014.

SPINILLO, C, G. An analytical approach to procedural pictorial sequences. Unpublished Ph.D dissertation. Department of Typography and Graphic Communication. University of Reading, UK, 2000 .

TEIXEIRA, T. A presença da infografia no jornalismo brasileiro - proposta de tipologia e classificação como gênero jornalístico a partir de um estudo de caso. Revista Fronteiras - estudos midiáticos, IX(2), 2007.

TUFTE, E. R. Envisioning Information. Graphics Press: Cheshire, CT: Graphics, 1990.

The visual display of quantitative information. Cheshire, CT: Graphics, 2001.

TWYMAN, M. A Schema for the Study of Graphic Language. KOLERS, P.A. \& WROSTAD, M.E. \& BOUMA, H. (Eds.), In: The Processing of Visible Language, vol. 1, Plenum, New York, 117-150, 1979.

. The graphic presentation of language. Information Design Journal, 3(1), 2-22, 1982.

VIEIRA, G.B.B. Design e Inovação: Projeto orientado para o mercado e centrado no usuário n. ${ }^{\circ} 4$. Revista Convergências, Revista de Investigação e Estudo das Artes, n.12, 2007.

VISOCKY O'GRADY, J. \& K. The information design handbook. How Books, 2008.

WURMAN, R.A. Information Anxiety 2. New York: New Riders Publishers, 2001 


\section{APÊNDICE A - ROTEIRO DA ENTREVISTA}

\section{Perguntas da entrevista com infografistas}

\section{Entrevistado número:}

Órgão do Governo:

PERFIL DO ENTREVISTADO

1. Gênero
() $\mathrm{M}($ ) $\mathrm{F}$

2. Faixa etária

() 18 a 25 anos () 26 a 30 anos ( ) 31 a 40 anos () 41 a 50 anos ( ) Mais de 50 anos

3. Formação acadêmica

() Fundamental Completo ( ) Fundamental Incompleto ( ) Médio Completo

( ) Médio Incompleto () Superior Completo () Superior Incompleto () Pós-graduado

4. Tipo de contratação

() Servidor público ( ) Terceirizado ( ) Consultor ( ) Estagiário

\section{Tempo de profissão}

() Menos de um ano ( ) 1 a 3 anos () 4 a 6 anos ( ) 7 a 10 anos () Mais de 10 anos

6. Há quanto tempo faz infográficos? () Menos de um ano ( ) 1 a 3 anos

() 4 a 6 anos () 7 a 10 anos ( ) Mais de 10 anos

7. Há quanto tempo faz infográficos para o governo?

( ) Menos de um ano ( ) 1 a 3 anos ( ) 4 a 6 anos ( ) 7 a 10 anos () Mais de 10 anos

8. Com qual frequência faz infográficos para o governo?

() Pouca ( ) Média ( ) Grande

9. Quantos infográficos já desenvolveu para o governo?

( ) até 10 ( ) 11 a 20 ( ) 21 a 30 ( ) 31 a 50 ( ) 51 a 100 ( ) Mais de 100

\section{ENTREVISTA SEMIESTRUTURADA SOBRE A ELABORAÇÃO DE INFOGRÁFICOS PARA O GOVERNO}

1. Você segue alguma metodologia de trabalho para elaboração de infográficos? Qual?

2. Como é o seu processo de elaboração de infográficos? (Pergunta aberta) 
a. Geralmente, quantos profissionais são envolvidos na elaboração de um infográfico? Qual a função de cada um deles?

b. O que busca como referências?

c. Quem determina que um infográfico deve ser elaborado para um determinado fim?

d. Qual o formato da informação que chega como insumo para a elaboração do infográfico? Ex: Explicação oral, Legislação, Planilhas, etc.

e. Quem determina quais informações farão parte do infográfico? Ex: Chefe do setor, chefe do projeto, designer, a equipe de desenvolvimento do site.

f. Quem elabora os textos/conteúdo que serão usados no infográfico? Você participa da elaboração dos textos/conteúdo?

3. Qual você acha que é a vantagem de um infográfico de informação pública (governamental)?

4. Você acha que os infográficos de informação pública (governamental) cumprem seus objetivos?

5. Quais os impedimentos para a elaboração de infográficos interativos para o governo, em sua opinião? Ex: Limitação técnica, acessibilidade, falta de equipe técnica especializada, prazo de execução, etc.

6. Geralmente há um objetivo a ser alcançado com o infográfico a ser elaborado?

7. Geralmente há uma determinação de como será medido se o infográfico alcançou seu objetivo?

8. Geralmente há algum teste com usuários? Em que momento do processo?

9. Seria bom ter feedback de usuários?

10. Há preocupação com a acessibilidade do infográfico?

11. Você conhece outros infografistas no governo? Vocês trocam informações? Acha que seria vantajoso trocar informações com eles? 


\section{APÊNDICE B - INFOGRÁFICOS ANALISADOS}

\section{Infográficos analisados quanto à linguagem gráfica}

1- Nome do Infográfico: Enem: entenda os critérios da prova

Responsável: Ministério da Educação

Data de publicação: 28/01/2014

Disponível em: http://www.brasil.gov.br/educacao/2014/04/enem-entenda-os-criterios-da-prova/

2- Nome do Infográfico: Conheça as categorias dos cursos do Projovem

Assinatura: Nenhuma

Data de publicação: 28/04/2014

Disponível em: http://www.brasil.gov.br/educacao/2014/04/conheca-as-categorias-dos-cursos-doprojovem/view

3- Nome do Infográfico: Conheça todos os detalhes do Ciência sem Fronteiras

Assinatura: Nenhuma

Data de publicação: 29/04/2014

Disponível em: http://www.brasil.gov.br/ciencia-e-tecnologia/2014/04/conheca-todos-os-detalhesdo-ciencia-sem-fronteiras/view

4- Nome do Infográfico: Informe-se sobre o programa Patentes Verdes

Assinatura: Nenhuma

Data de publicação: 29/04/2014

Disponível em: http://www.brasil.gov.br/ciencia-e-tecnologia/2014/04/informe-se-sobre-o-

programa-patentes-verdes/view

5- Nome do Infográfico: Como retirar os ingressos da Copa do Mundo

Assinatura: Nenhuma

Data de publicação: 19/05/2014

Disponível em: http://www.brasil.gov.br/esporte/2014/05/como-retirar-os-ingressos-da-copa-domundo/view 
6- Nome do Infográfico: Bandeiras tarifárias

Assinatura: Nenhuma

Data de publicação: 03/12/2014

Disponível em: http://www.brasil.gov.br/infraestrutura/2014/12/bandeirastarifarias/view

7- Nome do Infográfico: Confira a distribuição de jogos da Copa das Confederações

Assinatura: Nenhuma

Data de publicação: 15/04/2013

Disponível em: http://www.brasil.gov.br/esporte/2013/04/terceira-fase-de-vendas-de-ingressospara-a-copa-das-confederacoes-vai-ate-10-de-maio/confira-a-distribuicao-de-jogos-da-copa-dasconfederacoes/view

8- Nome do Infográfico: Igualdade racial é pra valer

Assinatura: Secretaria de Políticas de Promoção da Igualdade Racial

Data de publicação: 19/04/2013

Disponível em: http://www.brasil.gov.br/cidadania-e-justica/2013/03/igualdade-racial-1/view

9- Nome do Infográfico: Copa das Confederações movimenta economia local das cidades-sede Assinatura: Nenhuma

Data de publicação: 27/06/2013

Disponível em: http://www.brasil.gov.br/esporte/2013/06/copa-das-confederacoes-movimentaeconomia-local-das-cidades-sede/view

10- Nome do Infográfico: Vai viajar para assistir aos jogos da Copa das Confederações?

Assinatura: Nenhuma

Data de publicação: 27/06/2013

Disponível em: http://www.brasil.gov.br/esporte/2013/06/vai-viajar-para-assistir-aos-jogos-da-copadas-confederacoes/view

11- Nome do Infográfico: Família chefiada por mulheres

Assinatura: Nenhuma

Data de publicação: 17/02/2012 
Disponível em: http://www.brasil.gov.br/cidadania-e-justica/2012/02/familia-chefiada-pormulheres/view

12- Nome do Infográfico: Mulheres na Política

Assinatura: Nenhuma

Data de publicação: 23/04/2012

Disponível em: http://www.brasil.gov.br/cidadania-e-justica/2012/04/mulheres_na_politica/view

13- Nome do Infográfico: Consciência sustentável no Brasil

Assinatura: Nenhuma

Data de publicação: 04/10/2012

Disponível em: http://www.brasil.gov.br/meio-ambiente/2012/10/percepcoes-do-

brasileiro/consciencia-sustentavel-no-brasil/view

14- Nome do Infográfico: Economia de energia

Assinatura: Nenhuma

Data de publicação: 04/10/2012

Disponível em: http://www.brasil.gov.br/meio-ambiente/2012/10/energia-v3.jpg/view

15- Nome do Infográfico: Aprenda a economizar água

Assinatura: Nenhuma

Data de publicação: 20/12/2012

Disponível em: http://www.brasil.gov.br/meio-ambiente/2012/12/aprenda-a-economizar-agua/view

16- Nome do Infográfico: Conheça os bens imateriais brasileiros

Assinatura: Nenhuma

Data de publicação: 30/07/2014

Disponível em: http://www.brasil.gov.br/cultura/2014/06/conheca-os-bens-imateriais-

brasileiros/view

17- Nome do Infográfico: Caminho de Portugal na primeira fase

Assinatura: Portal da Copa - Ministério dos Esportes

Data de publicação: 30/07/2014

Disponível em: http://www.brasil.gov.br/esporte/2014/05/caminho_portugal_por_1.png/view 
18- Nome do Infográfico: Balanço de Vale-Cultura indica meio milhão de beneficiados Assinatura: Nenhuma

Data de publicação: 30/07/2014

Disponível em:http://www.brasil.gov.br/cultura/2014/04/balanco-de-vale-cultura-indica-meiomilhao-de-beneficiados/view

19- Nome do Infográfico: Confira como se deslocar em Natal

Assinatura: Nenhuma

Data de publicação: 12/05/2014

Disponível em: http://www.brasil.gov.br/turismo/2014/05/confira-como-se-deslocar-em-natal/view

20- Nome do Infográfico: Ciclo da Dengue

Assinatura: Nenhuma

Data de publicação: 18/03/2010

Disponível em: http://www.brasil.gov.br/saude/2010/03/ciclo_da_dengue/view 